\title{
Contrasting mafic to felsic HP-HT granulites of the Blanský les Massif (Moldanubian Zone of southern Bohemia): complexity of mineral assemblages and metamorphic reactions
}

\author{
Stanislav VRÁNA ${ }^{1 *}$, Vojtěch JANOUŠEK ${ }^{1,2}$, Jan FRANĚK ${ }^{1}$ \\ ${ }^{1}$ Czech Geological Survey, Klárov 3, 11821 Prague 1, Czech Republic; stanislav.vrana@geology.cz \\ ${ }^{2}$ Institute of Petrology and Structural Geology, Charles University, Albertov 6, 12843 Prague 2, Czech Republic \\ * Corresponding author
}

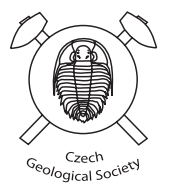

\begin{abstract}
A detailed petrological and geochemical study of the Blanský les Granulite Massif (BLGM; Moldanubian Zone of the Bohemian Massif) provides evidence for processes and mineral assemblages previously unrecognized, or not fully appreciated, in the South Bohemian HP-HT Granulite Complex. It also underlines the "patchwork"-like nature of the BLGM, caused by distinct protolith compositions as well as the differences in occurrence, or preservation, of mineral assemblages, reaction textures, and/or variable changes in chemical compositions. Such a complexity reflects superposition of several processes operating from the eclogite-facies metamorphic peak to the final emplacement, as well as variable resistance of individual rock types with distinct metamorphic fabrics.

Even on a thin section scale, domains preserving evidence for early phases of eclogite-facies metamorphism, including original textural relations and largely intact HP-HT mineral assemblages, occur in close proximity to domains dominated by phases produced during later decompression. Consistent high-pressure estimates, 2.2-2.3 GPa (GASP), are newly obtained for $\mathrm{S}_{1} / \mathrm{S}_{2}$ fabrics in the prevailing (type 1) felsic granulites, and correlate well with the recent finds of rare omphacite relics in the mafic granulites. It indicates that much of the HP history of the felsic and mafic rock types was shared and took place under eclogite-facies conditions.

Three important metamorphic processes leading to chemical changes in felsic granulites are described. (1) The small bodies of Kfs-dominated hyperpotassic granulites with minor Grt (or, rarely, Di) are fairly common and provide direct evidence for operation of non-eutectic HP melting. These occurrences are accompanied by compositionally complementary residual (type 2) felsic granulites, rich in Qtz and Ky and partly depleted in alkalis with Zr. Owing to their Ca-poor composition, type 2 granulites were not involved in some of the decompression reactions, such as formation of plagioclase rims around kyanite and garnet breakdown, and thus their mineral assemblages remained effectively "frozen" during decompression. They further imply that the partial melting and genesis of the hyperpotassic melts took place under eclogite-facies conditions. (2) Another case of syn-metamorphic modification is represented by a local limited base-cation loss during superimposed amphibolite-facies de-alkalization, accompanying fluid flux along $\mathrm{S}_{3}$ shear domains (formation of feldspar-free Qtz-Sill bands). (3) On a microscale, the retrogression reactions, often incomplete, were clearly associated with transfer of ions.

The felsic Moldanubian HP-HT granulites were assumed by several authors to have undergone only limited modification during peak metamorphism, most notably loss of Cs, Th and U. Clearly, some of them may have suffered more significant changes, such as perceptible loss of alkalis or even relatively immobile elements (e.g., zirconium), compared to the likely primary protolith(s) composition.
\end{abstract}

Keywords: granulites, eclogites, metamorphic reactions, high-pressure melting, petrology, Moldanubian Zone, Bohemian Massif Received: 12 August, 2013; accepted: 7 December, 2013; handling editor: G. Medaris

\section{Introduction}

Numerous occurrences of high-pressure (HP) granulites represent a characteristic feature of the Variscan orogen in central Europe. They typically form large bodies, up to several $100 \mathrm{~km}^{2}$ across (O'Brien and Carswell 1993; O’Brien and Rötzler 2003; Janoušek and Holub 2007; Faryad 2011), in which the prevalent felsic granulites are associated with other HP rocks like mafic granulites, garnet peridotites and (mafic) eclogites (Medaris et al. 2005, 2006 and references therein). Most occurrences are restricted to the so-called Gföhl Unit of the Moldanubian Zone (Fuchs 1976). The nature of protoliths to the HP rocks, the mechanism and timing of their passage through the mantle to lower crustal depths, and the subsequent exhumation to fairly high crustal levels represent cardinal problems of the Variscan Orogeny (e.g., Behr 1961, 1980; O’Brien 2000; O’Brien and Rötzler 2003; Medaris et al. 2006; Lexa et al. 2011). The most interesting stage in the evolution of HP granulite massifs is their early history, which took place at eclogite-facies conditions. Due to traditional $19^{\text {th }}$ century terminology, these high- 
grade rocks are nevertheless still called "felsic granulites" (O’Brien 2006).

The Blanský les Granulite Massif (BLGM), which is the object of the current study, stands out as an exceptionally large complex of eclogite-facies rocks in the framework of the European Variscides, having a total surface area near $240 \mathrm{~km}^{2}$. A survey of numerous publications dedicated to the petrology, geochronology and geochemistry of this body would show a strong preference of the authors for a few rock types, including felsic kyanite-garnet granulites of granitic or rhyolitic composition, mafic garnet-pyroxene granulites of basaltic or basaltic andesite composition, and garnet peridotites.

The present work is based on large body of newly collected samples, as well as $>400$ archival thin sections, coming mainly from the $1: 25,000$ geological map by Kodym (1981 1985). In this investigation we avoid inclusion of "typical felsic granulite" and "typical mafic granulite" samples, which were described previously in numerous publications. Instead, our attention is focused on other rock types recording complex metamorphic reactions, coexistence of various mineral generations, and evidence for processes that have not been previously observed or considered. Along these lines we will show that certain mineral assemblages and reactions are confined to some particular rock types, domains or even individual samples. This variability indicates a "patchwork" type of pattern in occurrence, or preservation, of mineral assemblages and reaction textures. The studies of such "aberrant" phenomena have the potential to elucidate additional complexity of processes that operated in the evolution of rocks in this body and, indeed, the Variscan orogenic root.

In this paper we will demonstrate that the evolution of most of the granulite types in the BLGM, mafic to felsic, can be traced back deep into the eclogite field ( $\mathrm{P}>2 \mathrm{GPa}$ ). Moreover, we will show that the history and original chemistry of the most common calc-alkaline granulites (termed type 1 here) can be particularly well assessed in relict $S_{1} / S_{2}$ domains in the southern part of the BLGM (Franěk et al. (2011a). Contrary to previous ideas, some of the most siliceous and Ky-rich granulites, designated as type 2, seem to be residual, i.e. significantly impoverished in a HP melt, which separated and formed nearby bodies of felsic hyperpotassic granulites dominated by $\mathrm{K}$-feldspar, well-known from previous works.

Also described for the first time are occurrences of magnetite-bearing granulitic rocks, in addition to the predominant and well-known graphite-bearing assemblages. Lastly is documented a decompressional trend from HP kyanite-garnet felsic granulites to orthopyroxene-garnet charnockites, following the consumption of kyanite.

\section{Geological setting}

\subsection{Moldanubian Zone in the Bohemian Massif}

The Bohemian Massif (Fig. 1) consists of the Saxothuringian Zone to the West, the Teplá-Barrandian and Moldanubian zones in the centre (Kossmat 1927) and the Brunovistulian microcontinent to the east (Dudek 1980). The Moldanubian Zone is interpreted as an orogenic root developed during the Late Devonian to Early Carboniferous collision between Gondwana and Laurussia (Schulmann et al. 2009). It has been traditionally subdivided into several main rock assemblages (Fig. 1a): the medium-grade Varied and Monotonous units, the highgrade Gföhl Unit, and allochthonous segments of older continental crust represented mainly by the Dobra gneiss (dominated by a $\sim 1.38$ Ga zircon component, Gebauer and Friedl 1994; Friedl et al. 2004) in Lower Austria and the Světlík orthogneiss (2.1 Ga protolith age, Wendt et al. 1993; Trubač et al. 2012) in southern Bohemia. Both the amphibolite-facies Monotonous and Varied units are dominated by Sill-Bt paragneisses, with amphibolite bodies, minor orthogneisses and medium-temperature eclogites. As the name suggests, characteristic of the Varied Unit is the presence of marbles, quartzites, calcsilicate rocks and graphitic gneisses (Fiala et al. 1995).

\subsection{Gföhl Unit}

This unit includes anatectic Gföhl orthogneisses (Cooke and O’Brien 2001; Hasalová et al. 2008), MORB-like amphibolite of the so-called Begleit Series (Finger and Steyrer 1995; Fritz 1995) and HP granulites, associated with variably sized bodies of garnet and spinel peridotites, pyroxenites, dunites and (mafic) eclogites (e.g., Fuchs and Matura 1976; Fiala et al. 1995; Medaris et al. 2005; O’Brien and Rötzler 2003). The earlier works viewed the Gföhl Unit as isolated klippen of an original regionally extensive nappe (Fuchs and Matura 1976; Tollmann 1982). However, other workers stressed that nappe structures in southern Bohemia, if ever present, were strongly overprinted by later deformation phases (Rajlich et al. 1986; Vrána and Šrámek 1999).

The simple nappe concept has recently been questioned both in Lower Austria (Racek et al. 2006) and Bohemia (Štípská et al. 2004; Franěk et al. 2006, 2011a). The current model proposes a gravity-driven vertical extrusion of thermally softened orogenic lower crust (Lexa et al. 2011). Subsequent mid-crustal reworking of extruded high-grade metamorphic rocks and (ultra-) potassic intrusions of the 'durbachite suite' (Holub 1997; Verner et al. 2008) was attributed to the indentation of the 


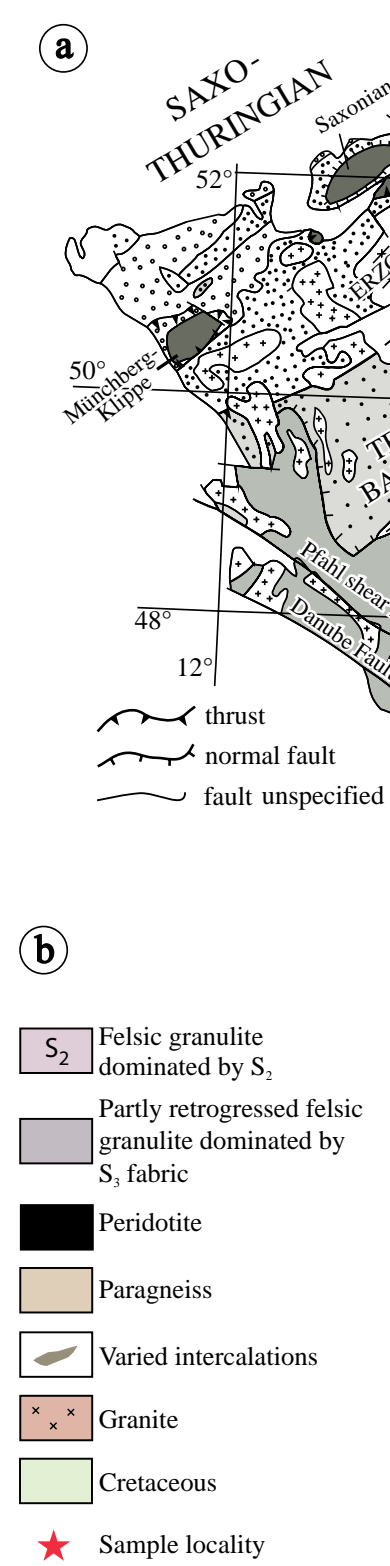

Fig. 1a - Principal tectonic division of the Bohemian Massif, modified after Franke (2000). b - Simplified geological sketch of the Blanský les granulite Massif based on maps 1:50 000 published by the Czech Geological Survey. The position of study area within the Bohemian Massif is indicated in the inset (a). Locations of the samples for whole-rock geochemical work are also shown.
SAXOTHURINGIAN, LUGIAN

$\because$ Early Carboniferous

$\therefore$ (very low-grade)

$\because \cdots$ Proterozoic to Devonian

$\because \therefore \therefore$ (very low to medium-grade)

Crystalline units (high-grade)

* L ate Proterozoic granitoids \& sediments, very low to high-grade

TEPLÁ - BARRANDIAN

$\because \because \because$ Proterozoic (very low to medium$\therefore \therefore \therefore$ grade) with Prevariscan intrusives $\because \therefore$ Early Palaeozoic $\because \because$ (not metamorphosed)

\section{MOLDANUBIAN}

Gföhl Unit (high-grade)

Monotonous \& Varied groups (medium-grade)

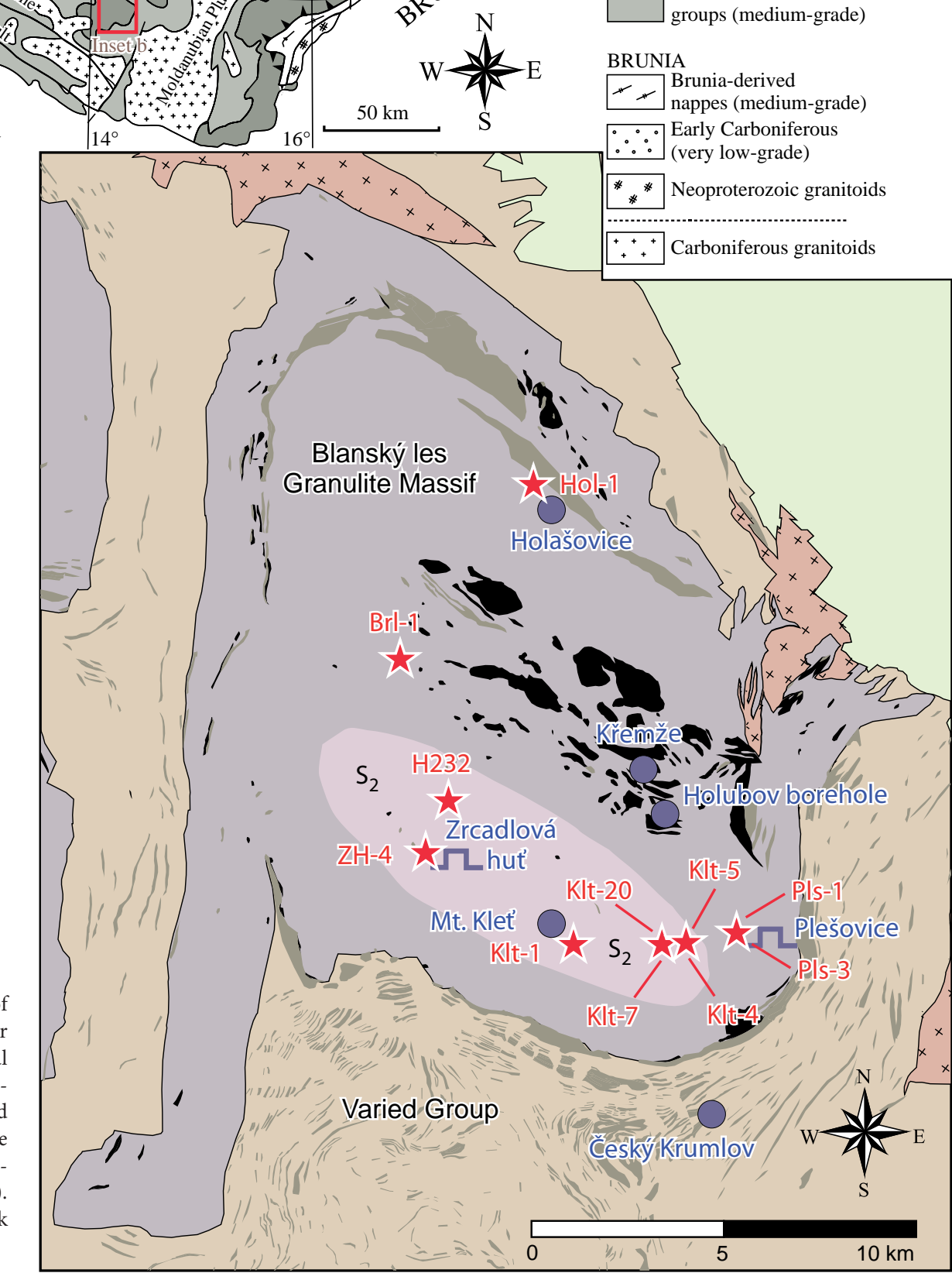


Brunia continent into the weak orogenic root (Schulmann et al. 2008).

\subsection{High-pressure granulites}

\subsubsection{Petrology}

In southern Bohemia, the ubiquitous granulite massifs, enclosing subordinate bodies of mantle-derived ultramafic rocks of various sizes (up to $5 \mathrm{~km}$ across), tend to be roughly oval-shaped. The largest among them is the Blanský les Massif $(24 \times 14 \mathrm{~km})$, followed by the Křišt'anov, Prachatice, Lišov and Krasejovka bodies. However, most granulites from the Lišov and Krasejovka massifs do not belong to the HP family, as their peak metamorphic conditions likely never exceeded c. $800-900{ }^{\circ} \mathrm{C}$ and $0.4-0.5$ GPa (Janoušek et al. 2006b).

In the remaining HP granulite massifs (termed here the South Bohemian HP-HT Granulite Complex), acid metaigneous granulites $\left(\mathrm{SiO}_{2}>70 \%\right)$ strongly prevail over basic to intermediate pyroxene-bearing granulites, sedimentary-derived granulites and other types (Fiala et al. 1987a). A peak assemblage of garnet, quartz and unmixed hypersolvus feldspar, commonly with kyanite and/or biotite, characterizes typical felsic HP granulites. Rutile, zircon, apatite, ilmenite \pm monazite are the common accessories (Vellmer 1992; O’Brien and Rötzler 2003; Kotková 2007 and references therein).

\subsubsection{P-T conditions}

Even though the south Bohemian granulites have clearly recorded high-pressure conditions (at least 1.3-1.5 GPa: Pin and Vielzeuf 1988), the peak temperatures remain a matter of controversy, with estimates varying between c. 850 and $1050^{\circ} \mathrm{C}$ depending on the massif studied and the method used (Kröner et al. 2000; Štípská and Powell 2005; O'Brien 2008; Kotková and Harley 2010; Franěk et al. 2011b; Tajčmanová et al. 2012).

Further evolution was characterised by near isothermal decompression (to 0.8-0.5 GPa), variable retrogression and intense deformation, reflecting the effects of exhumation of the deep-seated Moldanubian root (Carswell and O’Brien 1993; Verner et al. 2008). In more felsic rocks these processes resulted in local inversion of kyanite to sillimanite or development of plagioclase rims around the former alumosilicate, as well as breakdown of garnet to a secondary biotite or plagioclase-orthopyroxene coronas, and kyanite to hercynite and garnet coronas. Mafic and intermediate granulites typically show garnet overgrown by a corona-symplectite decompression assemblage of $\mathrm{Pl}+\mathrm{Opx} \pm \mathrm{Cpx}$ and Hbl (Owen and Dostal 1996). In southern Bohemia (e.g., Prachatice and Blanský les massifs) a low-P high-T overprint led to the crystallization of cordierite and formation of partial melt patches (O'Brien 2000; Kröner et al. 2000); during uplift, the andalusite stability field was reached (Fediuková 1971; Vrána 1992).

\subsubsection{Age of the Variscan eclogite/granulite- -facies metamorphism}

The high-grade metamorphism in the Moldanubian granulite massifs is thought to have occurred at $c$. $340 \mathrm{Ma}$ (conventional U-Pb ages for zircon and monazite, SHRIMP ages on zircon rims/multifaceted metamorphic grains: van Breemen et al. 1982; Wendt et al. 1994; Kröner et al. 2000; Friedl et al. 2003, 2011). The most precise determinations timing the HP event are $\mathrm{U}-\mathrm{Pb}$ zircon ages from hyperpotassic granulites of the Blanský les Massif (Aftalion et al. 1989: $338 \pm 1$ Ma; Sláma et al. 2008: $337.13 \pm 0.37 \mathrm{Ma}$ ). Svojtka et al. (2002) concluded, based on Sm-Nd ages for garnet cores with prograde zoning, that the HP-HT metamorphic peak may have been c. 10-15 Ma older (354 \pm 5 Ma: Prince et al. 2000). Even older Sm-Nd Grt ages were reported from Moldanubian granulites (Janoušek et al. 1996; Chen 2002), but are likely spurious and probably reflect variable degrees of Variscan disequilibria (Romer and Rötzler 2011). On the other hand, modern ion-probe data indicate that there could have been two high-grade metamorphic events separated by several Ma (342 \pm 3 and $337.1 \pm 2.7$ Ma: Friedl et al. 2011 or $339 \pm 3$ and $336 \pm 4$ Ma: Harley 2013). The lower age limit of the peak HP metamorphism is constrained by c. 342-339 Ma durbachite intrusions (Janoušek et al. 2010 and references therein), which crosscut exhumation-related structures in granulites (Verner et al. 2008).

\subsubsection{Composition and likely protolith(s) to the HP granulites}

Although whole-rock geochemistry is a powerful tool to decipher, or at least constrain, the nature of protoliths of the HP granulites, previous studies focussed exclusively on the most widespread 'typical' felsic granulites, and relatively little attention has been paid to the more mafic or 'exotic' lithologies (Fiala et al. 1987a; Vellmer 1992; Janoušek et al. 2004).

Most of the felsic granulites have undepleted LILE inventories, except for Cs, U and Th (Fiala et al. 1987a; Janoušek et al. 2004; Lexa et al. 2011). Based on low whole-rock $\mathrm{Zr}$ contents (coupled with significant preVariscan inheritance), chondrite-normalized REE patterns with moderate to weak LREE/HREE enrichment and negative $\mathrm{Eu}$ anomalies, and crustal $\mathrm{Sr}-\mathrm{Nd}$ isotopic signatures, the felsic granulites resemble ordinary (lowpressure) fractionated felsic igneous rocks, such as leucogranites or rhyolites (Janoušek et al. 2004), and not 
separated high-pressure melts (Jakeš 1997; Kotková and Harley 1999).

However, thermodynamic modelling demonstrated that a certain degree of partial melting (anatexis) was inevitable, albeit not great $(<10-15 \%)$, as the presumed protolith was highly refractory (Janoušek et al. 2004; Lexa et al. 2011). Indeed, the presence of some melt can be convincingly demonstrated by petrographic observations (O’Brien and Rötzler 2003), experiments (Tropper et al. 2005), and trace-element variations in garnet, rutile and zircon (Kotková and Harley 2010). Igneous protoliths of the felsic granulites are compositionally similar to Ordovician-Silurian metarhyolites and orthogneisses preserved in the Saxothuringian Zone (Janoušek and Holub 2007). The most appropriate geotectonic setting for this widespread igneous activity throughout Variscan Europe (e.g., Pin and Marini 1993) seems to be attenuated crust of a Gondwana intracontinental or back-arc rift (Siebel et al. 1997; Linnemann et al. 2000). The high Nd model ages testify that the source of the magmas could have been a pre-existing crust, possibly Cadomian I-type granodiorites, or geochemically undistinguishable immature psammitic metasediments, all readily available at the Gondwana margin (Janoušek et al. 2004).

\subsubsection{Structure of the studied Blanský Les Granulite Massif}

The structural geology of the BLGM and emplacement mechanisms have been dealt with by Kodym (1972), Svojtka et al. (2002) and Franěk et al. (2006, 2011a). Polyphase deformation of metasedimentary units surrounding granulites were studied by Vrána (1979), Rajlich et al. (1986), Vrána and Šrámek (1999) and Franěk et al. (2011a). Franěk et al. (2006) reported the following succession of three ductile fabrics in the BLGM. The oldest one, $\mathrm{S}_{1}$, is represented by rarely preserved compositional banding defined by an alternation of $\leq 1 \mathrm{~cm}$ thick quartz-rich bands, $\leq 1 \mathrm{~cm}$ thick bands of recrystallized alkali feldspar and 1-3 $\mathrm{mm}$ thick darker plagioclasegarnet-biotite-dominated bands. The feldspar-rich bands preserve large perthite porphyroclasts $(\leq 1 \mathrm{~cm})$ with numerous inclusions. The $S_{1}$ foliation is reworked by mesoscopic passive $\mathrm{F}_{2}$ folding with steep $\mathrm{N}-\mathrm{S}$ trending axial planes and penetratively developed axial cleavage $\mathrm{S}_{2}$. The $\mathrm{S}_{2}$ foliation is defined by strong subhorizontal elongation of quartz ribbons (so-called "platy quartz"), biotite aggregates and weak mm-scale compositional banding. It displays a strong sub-horizontal $\mathrm{L}_{2}$ stretching and mineral lineation. Both the $\mathrm{S}_{1}$ and $\mathrm{S}_{2}$ fabrics are preserved mainly in an $8.5 \times 2.5 \mathrm{~km}$ relict domain (Fig. 1) in an elliptical area in the southern part of the BLGM, where a syntectonic mineral assemblage of $\mathrm{Kfs}-\mathrm{Pl}-\mathrm{Qtz}-$
Grt-Ky-Bt indicates HP-HT conditions during both the deformations. Kyanite grains in $\mathrm{S}_{1}$ and $\mathrm{S}_{2}$ are commonly surrounded by decompressional Pl rims (Tajčmanová et al. 2007). Mafic boudins enclosed in $S_{1}$ and $S_{2}$ are crosscut by cm to dm-thick Kfs-Pl-Qtz-Grt-Ky felsic dykes, which document the presence of limited amount of felsic melt during the HP-HT deformation. At the margin of the relict domain, the $\mathrm{S}_{2}$ fabric is transposed by mesoscopic $\mathrm{F}_{3}$ folding and development of steeply dipping penetrative axial cleavage $\mathrm{S}_{3}$ defined by elongated biotite aggregates. The $S_{3}$ foliation penetratively overprints the older fabrics in the majority of the BLGM and forms an $18 \mathrm{~km}$ wide sigmoidal asymmetric fold parallel to the margins of the massif, with moderately dipping fold axes and steep N-S trending axial planes. It shows heterogeneous retrogressive syntectonic replacement of kyanite by sillimanite and garnet by biotite, which indicates amphibolite-facies conditions during deformation. Syntectonic retrogression was accompanied by heterogeneous hydration, mainly in the outer parts of the granulite body that resulted in partial melting to form a rock type called "granulitic gneiss". The complex tectonic history and early exhumation in a form resembling a forced diapir was described in Franěk et al. (2011a), Lexa et al. (2011) and Maierová et al. (in print).

The surrounding Moldanubian Zone in southern Bohemia shows an exceptionally complex Variscan tectonic history, including three stages of amphibolite-facies shearing and refoliation superimposed on the primary high-grade tectonic structure $\left(D_{1}\right)$. The superimposed deformations took place with variable orientations of stress-field and featured notably heterogeneous deformation. This resulted in a complicated pattern of structural relics belonging to various early generations that are separated by intervening, younger shearing domains (Vrána and Šrámek 1999; Franěk et al. 2011a). The preserved domains of primary high-grade tectonic structure are estimated to constitute less than $10 \%$ of the wider region. In combination with poor exposures, this complexity has resulted in less effective application of structural methods than in better exposed and/or tectonically simpler terrains. A nicely wrapped tectonic-metamorphic interpretation would thus rely on over-interpretation of tectonic data from the limited relict domains.

\section{Methods}

\subsection{Petrology and mineral chemistry}

Polished thin sections were studied using optical microscopy with the aim of textural description, mineral identification, observation of the types of metamorphic reactions and preparation for electron microprobe work. 
Full size images of thin sections were scanned to expedite microprobe work.

Mineral analyses were obtained using a CAMECA SX 100 WDS electron microprobe at the Joint Laboratory of Electron Microscopy and Microanalysis, Department of Geological Sciences, Masaryk University and the Czech Geological Survey, Brno. The analytical conditions varied according to the mineral analysed, typically including $15 \mathrm{kV}$ accelerating voltage, 10-20 nA probe current and acquisition time of 10-30 s. The standards used were spessartine ( $\mathrm{Si}, \mathrm{Mn})$, sanidine $(\mathrm{Al}, \mathrm{K})$, almandine (Fe), hornblende (Ti), andradite (Ca), $\mathrm{MgAl}_{2} \mathrm{O}_{4}$ $(\mathrm{Mg})$, albite $(\mathrm{Na})$, fluorapatite $(\mathrm{P})$, chromite $(\mathrm{Cr})$ and other materials for REE and some minor elements. Mineral formulae were calculated using the spreadsheets by Tindle (2012). Mineral abbreviations in this paper follow (Kretz 1983) and (Grew 1996), except baddeleyite - Bd. The approximate proportions of the main rock-forming minerals (wt. \%) were obtained by the constrained leastsquares method (Albaréde 1995) implemented in the GCDkit (Janoušek et al. 2006a). The calculation was based on whole-rock chemical analyses and representative microprobe analyses of minerals. In one case, where there were additional phases present, the estimate is based on the Catanorm (Hutchison 1975). Where no whole-rock chemical analysis was available due to small sample size, the modal percentages are based on visual estimates. Also proportions of some minor and accessory minerals were estimated by microscopy.

Pressure and temperature estimates are based on spot analyses from local small domains in adjacent mineral grains, presuming such grains to be in local equilibrium. GASP barometry (Koziol and Newton 1988), Grt-Cpx thermometry (Raheim and Green 1974; Powell 1985; Ganguly et al. 1996), Bt-Opx thermometry (Sengupta et al. 1990), and Grt-Bt thermometry (Indares and Martignole 1985) were applied. In felsic granulites of granite composition the presence of unmixed ternary feldspar in the form of mesoperthite is often considered as a major obstacle in using GASP barometry (O'Brien and Rötzler 2003). It is noteworthy that some of our samples are of granodiorite composition and that plagioclase was in equilibrium with mesoperthite during the HP-HT metamorphic stage. The felsic rocks of (leuco-) granite composition commonly show a minor quantity of early primary plagioclase $(<c .5$ vol. \%), which co-existed with ternary feldspar (Mora and Valley 1985). We have observed uncommon, relatively large plagioclase inclusions in garnet I and used them for pressure estimates. The barometry values should be considered as minimum pressure estimates with probable error of $\pm 0.2 \mathrm{GPa}$. The limited ability of silicate assemblages to record and retain evidence for ultrahigh-pressure conditions is seen in the rare preservation of microdiamonds in gneiss, e.g. in sei- denbachite (microdiamond-bearing Ky-Ms-Grt gneiss) in Erzgebirge, Bohemian Massif (Massonne and Nasdala 2003; Massonne and Fockenberg 2012).

\subsection{Major-element whole-rock composition}

Major-element analyses of whole-rock samples (at least 10-15 kg each) were undertaken by wet chemistry in the laboratories of the Czech Geological Survey, Prague-Barrandov. The relative $2 \sigma$ uncertainties were smaller than $1 \%\left(\mathrm{SiO}_{2}\right), 2 \%(\mathrm{FeO}), 5 \%\left(\mathrm{Al}_{2} \mathrm{O}_{3}, \mathrm{~K}_{2} \mathrm{O}, \mathrm{Na}_{2} \mathrm{O}\right), 7 \%$ $\left(\mathrm{TiO}_{2}, \mathrm{MnO}, \mathrm{CaO}\right), 6 \%(\mathrm{MgO})$ and $10 \%\left(\mathrm{Fe}_{2} \mathrm{O}_{3}, \mathrm{P}_{2} \mathrm{O}_{5}\right)$. Data handling, recalculation and plotting were performed by the R language package GCDkit (Janoušek et al. 2006a), version 3 .

\section{Major-element whole-rock geochemistry}

The systematic variability in major-element whole-rock geochemical compositions of the individual rock types making up the BLGM has never been properly addressed. The best studied types are mainly granulitic rocks, with leucogranulites prevailing over more mafic and ultrabasic types, from the deep borehole drilled in 1965 near the village of Holubov (Fig. 1) (Kodym et al. 1978; Fediuková 1978), revisited by Janoušek et al. (2004, 2007). The other locality known in some detail is the large Plešovice quarry (Strejček 1986), with particular emphasis on the hyperpotassic granulites (Vrána 1989; Janoušek et al. 2007). Seven major-element analyses from the Lichtenstein quarry (on the slopes of Mt. Klet'), as well as the Plešovice and Zrcadlová Hut' quarries were presented by Slabý (1983) and thirteen by Fiala et al. (1987a, b). Unfortunately the data of the latter authors lack determinations of ferrous/ferric iron and of volatile components. Moreover, they are recast to $100 \mathrm{wt}$ \% on an anhydrous basis, and thus their quality is uncertain.

The current investigation does not aim to discuss the complete whole-rock geochemical variability of the BLGM granulites. This complex issue will be the theme of a separate contribution, which is currently under preparation. The major-element compositions are simply used here as essential information determining, along with the $\mathrm{P}-\mathrm{T}-\mathrm{t}$ conditions, the petrogenesis of the studied granulite types. Samples described in the text are presented in Tab. 1 and plotted in Fig. 2 on the background of a recent, large dataset from localities throughout the BLGM, supplemented by previously published analyses from the Holubov borehole and hyperpotassic granulites carried out in the same laboratory by identical methods (Janoušek et al. 2004, 2007, 2013). In total, 53 wet analyses are available, divided here rather arbitrarily into the following groups: basic $\left(\mathrm{SiO}_{2}<52\right.$ wt. \%), intermediate 
Tab. 1 Selected major-element analyses (wt. \%) from variable rock types of the BLGM

\begin{tabular}{|c|c|c|c|c|c|c|c|c|c|c|c|}
\hline \multirow{2}{*}{$\begin{array}{l}\text { Rock } \\
\text { Locality }\end{array}$} & \multirow{2}{*}{$\begin{array}{c}\text { Klt-5 } \\
\text { basic } \\
\text { granulite } \\
\begin{array}{c}\text { Klet', } \\
\text { slopes }\end{array}\end{array}$} & \multirow{2}{*}{$\begin{array}{c}\text { H232 } \\
\text { intermediate } \\
\text { granulite } \\
\text { Zrcadlová } \\
\text { Hut' } \\
\text { quarry } \\
\end{array}$} & \multirow{2}{*}{$\begin{array}{c}\text { Klt-7 } \\
\text { hyper- } \\
\text {-potassic } \\
\text { granulite } \\
\text { Kokotín }\end{array}$} & \multirow{2}{*}{$\begin{array}{c}\text { Klt-1 } \\
\text { transitional } \\
\text { granulite } \\
\text { Klet', } \\
\text { summit }\end{array}$} & \multicolumn{2}{|c|}{$\begin{array}{l}\text { ZH-4 Klt-4 } \\
\text { felsic granulite } \\
\text { (type 1) }\end{array}$} & \multicolumn{2}{|c|}{$\begin{array}{l}\text { Pls-1 } \text { Klt-20 }^{\dagger} \\
\text { residual felsic } \\
\text { granulite (type 2) }\end{array}$} & \multirow{2}{*}{$\begin{array}{c}\text { Pls-3 } \\
\text { felsic gra } \\
\text { Plešovice } \\
\text { quarry }\end{array}$} & \multirow{2}{*}{$\begin{array}{c}\text { Brl-1 } \\
\text { nulite (de-a } \\
\text { hill NE } \\
\text { of Brloh }\end{array}$} & \multirow{2}{*}{$\begin{array}{c}\text { Hol-1 } \\
\text { alkalized) } \\
\text { Holašovice, } \\
\text { disused } \\
\text { quarry } \\
\end{array}$} \\
\hline & & & & & $\begin{array}{c}\text { Zrcadlová } \\
\text { Hut' } \\
\text { quarry }\end{array}$ & $\begin{array}{l}\text { Klet', } \\
\text { slopes }\end{array}$ & $\begin{array}{c}\text { Plešovice } \\
\text { quarry }\end{array}$ & Kokotín & & & \\
\hline $\mathrm{SiO}_{2}$ & 45.77 & 58.66 & 64.52 & 68.37 & 72.86 & 73.01 & 76.40 & 76.81 & 73.33 & 76.67 & 79.32 \\
\hline $\mathrm{TiO}_{2}$ & 2.63 & 0.87 & 0.07 & 0.55 & 0.26 & 0.26 & 0.08 & 0.05 & 0.34 & 0.12 & 0.18 \\
\hline $\mathrm{Al}_{2} \mathrm{O}_{3}$ & 13.95 & 14.18 & 18.21 & 14.97 & 13.65 & 13.78 & 12.34 & 12.18 & 13.19 & 11.80 & 11.25 \\
\hline $\mathrm{Fe}_{2} \mathrm{O}_{3}$ & 2.82 & 1.45 & $<0.01$ & 0.81 & 0.19 & 0.17 & 0.12 & 1.61 & 0.34 & 0.14 & 0.14 \\
\hline $\mathrm{FeO}$ & 9.89 & 7.26 & 0.40 & 4.09 & 2.38 & 2.17 & 1.49 & - & 1.96 & 1.80 & 0.65 \\
\hline $\mathrm{MnO}$ & 0.183 & 0.151 & 0.012 & 0.066 & 0.042 & 0.042 & 0.049 & 0.020 & 0.034 & 0.036 & 0.010 \\
\hline $\mathrm{MgO}$ & 8.70 & 4.64 & 0.10 & 1.69 & 0.78 & 0.69 & 0.34 & 0.08 & 0.62 & 0.21 & 0.53 \\
\hline $\mathrm{CaO}$ & 9.46 & 7.70 & 0.52 & 2.67 & 1.73 & 1.55 & 0.61 & 0.26 & 0.84 & 0.50 & 0.75 \\
\hline $\mathrm{SrO}$ & 0.028 & 0.005 & 0.045 & 0.007 & 0.011 & 0.009 & 0.005 & - & 0.008 & $<0.005$ & 0.007 \\
\hline $\mathrm{BaO}$ & 0.012 & 0.015 & 0.246 & 0.057 & 0.067 & 0.059 & 0.010 & - & 0.040 & 0.009 & 0.018 \\
\hline $\mathrm{Li}_{2} \mathrm{O}$ & 0.004 & 0.008 & 0.002 & 0.008 & 0.010 & 0.004 & 0.010 & 0.003 & 0.017 & 0.007 & 0.004 \\
\hline $\mathrm{Na}_{2} \mathrm{O}$ & 2.82 & 2.65 & 1.31 & 3.58 & 2.77 & 2.93 & 2.97 & 2.85 & 2.70 & 2.36 & 2.98 \\
\hline $\mathrm{K}_{2} \mathrm{O}$ & 0.57 & 0.93 & 13.08 & 2.28 & 4.50 & 4.45 & 4.27 & 4.11 & 5.17 & 4.94 & 2.71 \\
\hline $\mathrm{P}_{2} \mathrm{O}_{5}$ & 0.395 & 0.116 & 0.440 & 0.074 & 0.182 & 0.153 & 0.090 & 0.060 & 0.204 & 0.196 & 0.091 \\
\hline $\mathrm{CO}_{2}$ & 0.563 & 0.031 & $<0.010$ & $<0.010$ & $<0.010$ & $<0.010$ & $<0.010$ & - & $<0.010$ & $<0.010$ & $<0.010$ \\
\hline F & 0.105 & 0.052 & 0.061 & 0.072 & 0.071 & 0.067 & 0.030 & - & 0.113 & 0.087 & 0.088 \\
\hline C (rest.) & 0.024 & 0.009 & 0.014 & 0.005 & 0.006 & 0.016 & 0.027 & - & $<0.005$ & 0.018 & 0.044 \\
\hline S (tot.) & 0.189 & 0.081 & $<0.010$ & 0.105 & 0.034 & $<0.010$ & $<0.010$ & - & 0.015 & $<0.011$ & 0.018 \\
\hline F (equiv) & -0.044 & -0.022 & -0.026 & -0.030 & -0.030 & -0.028 & -0.014 & - & -0.048 & -0.037 & -0.037 \\
\hline S (equiv) & -0.047 & -0.020 & 0.000 & -0.026 & -0.008 & -0.001 & -0.001 & - & -0.004 & -0.003 & -0.004 \\
\hline $\mathrm{H}_{2} \mathrm{O}^{+}$ & 1.330 & 0.489 & 0.330 & 0.306 & 0.281 & 0.340 & 0.200 & 0.190 & 0.623 & 0.295 & 0.490 \\
\hline $\mathrm{H}_{2} \mathrm{O}^{-}$ & 0.05 & 0.09 & $<0.05$ & 0.11 & 0.05 & 0.09 & 0.10 & $<0.05$ & 0.12 & 0.05 & 0.06 \\
\hline$\Sigma$ & 99.40 & 99.35 & 99.33 & 99.76 & 99.84 & 99.76 & 99.13 & 98.22 & 99.61 & 99.20 & 99.30 \\
\hline $\mathrm{FeOt}$ & 12.43 & 8.56 & 0.40 & 4.82 & 2.55 & 2.32 & 1.60 & 1.45 & 2.27 & 1.93 & 0.78 \\
\hline $\mathrm{FeOt} / \mathrm{MgO}$ & 1.43 & 1.85 & 4.00 & 2.85 & 3.27 & 3.37 & 4.70 & 18.11 & 3.65 & 9.17 & 1.46 \\
\hline $\mathrm{FeOt} /(\mathrm{FeOt}+\mathrm{MgO})$ & 0.59 & 0.65 & 0.8 & 0.74 & 0.77 & 0.77 & 0.82 & 0.95 & 0.79 & 0.9 & 0.59 \\
\hline $\mathrm{K}_{2} \mathrm{O} / \mathrm{Na}_{2} \mathrm{O}$ & 0.2 & 0.35 & 9.98 & 0.64 & 1.62 & 1.52 & 1.44 & 1.44 & 1.91 & 2.09 & 0.91 \\
\hline $\mathrm{A} / \mathrm{CNK}$ & 0.62 & 0.73 & 1.06 & 1.13 & 1.09 & 1.11 & 1.16 & 1.27 & 1.14 & 1.16 & 1.22 \\
\hline mg\# & 55.51 & 49.13 & 30.83 & 38.47 & 35.28 & 34.62 & 27.5 & 8.96 & 32.78 & 16.27 & 54.9 \\
\hline $\mathrm{Q}^{\ddagger}$ & 0.00 & 13.89 & 6.17 & 26.63 & 31.74 & 31.75 & 38.23 & 42.45 & 32.98 & 40.23 & 47.21 \\
\hline C & 0.00 & 0.00 & 2.28 & 2.35 & 1.85 & 2.04 & 2.24 & 3.09 & 2.65 & 2.61 & 2.80 \\
\hline Or & 3.45 & 5.64 & 78.06 & 13.72 & 27.13 & 26.83 & 25.96 & 25.29 & 31.34 & 30.16 & 16.53 \\
\hline Plag & 50.21 & 49.15 & 11.42 & 45.24 & 32.51 & 33.27 & 29.79 & 27.59 & 27.07 & 22.61 & 30.25 \\
\hline $\mathrm{Ab}$ & 25.92 & 24.44 & 11.88 & 32.73 & 25.38 & 26.84 & 27.44 & 26.66 & 24.87 & 21.90 & 27.63 \\
\hline An & 24.29 & 24.71 & -0.46 & 12.51 & 7.13 & 6.43 & 2.34 & 0.94 & 2.19 & 0.71 & 2.62 \\
\hline Ну & 9.09 & 17.38 & 0.83 & 9.95 & 5.52 & 4.95 & 3.22 & 0.23 & 4.20 & 3.27 & 2.21 \\
\hline $\mathrm{Di}$ & 13.56 & 10.60 & 0.00 & 0.00 & 0.00 & 0.00 & 0.00 & 0.00 & 0.00 & 0.00 & 0.00 \\
\hline Wo \% & 50.00 & 50.00 & 0.00 & 0.00 & 0.00 & 0.00 & 0.00 & 0.00 & 0.00 & 0.00 & 0.00 \\
\hline En \% & 35.33 & 29.02 & 0.00 & 0.00 & 0.00 & 0.00 & 0.00 & 0.00 & 0.00 & 0.00 & 0.00 \\
\hline Fs \% & 14.67 & 20.98 & 0.00 & 0.00 & 0.00 & 0.00 & 0.00 & 0.00 & 0.00 & 0.00 & 0.00 \\
\hline $\mathrm{Ol}$ & 14.20 & 0.00 & 0.00 & 0.00 & 0.00 & 0.00 & 0.00 & 0.00 & 0.00 & 0.00 & 0.00 \\
\hline Fo \% & 70.66 & 0.00 & 0.00 & 0.00 & 0.00 & 0.00 & 0.00 & 0.00 & 0.00 & 0.00 & 0.00 \\
\hline Fa \% & 29.34 & 0.00 & 0.00 & 0.00 & 0.00 & 0.00 & 0.00 & 0.00 & 0.00 & 0.00 & 0.00 \\
\hline Mt & 3.02 & 1.56 & 0.00 & 0.86 & 0.20 & 0.18 & 0.13 & 0.00 & 0.36 & 0.15 & 0.15 \\
\hline $\mathrm{Hm}$ & 0.00 & 0.00 & 0.00 & 0.00 & 0.00 & 0.00 & 0.00 & 1.17 & 0.00 & 0.00 & 0.00 \\
\hline Il & 3.75 & 1.25 & 0.10 & 0.78 & 0.37 & 0.37 & 0.11 & 0.03 & 0.49 & 0.17 & 0.26 \\
\hline $\mathrm{Ru}$ & 0.00 & 0.00 & 0.00 & 0.00 & 0.00 & 0.00 & 0.00 & 0.02 & 0.00 & 0.00 & 0.00 \\
\hline Ap & 0.95 & 0.28 & 1.05 & 0.18 & 0.44 & 0.37 & 0.22 & 0.13 & 0.49 & 0.48 & 0.22 \\
\hline $\mathrm{Fr}$ & 0.32 & 0.19 & 0.10 & 0.29 & 0.25 & 0.24 & 0.10 & 0.00 & 0.43 & 0.32 & 0.36 \\
\hline Cc & 1.46 & 0.08 & 0.00 & 0.00 & 0.00 & 0.00 & 0.00 & 0.00 & 0.00 & 0.00 & 0.00 \\
\hline Sum & 100.00 & 100.00 & 100.00 & 100.00 & 100.00 & 100.00 & 100.00 & 100.00 & 100.00 & 100.00 & 100.00 \\
\hline
\end{tabular}

${ }^{\dagger}$ analyses from Janoušek et al. (2013)

₹ Catanormative compositions (Hutchison 1975)

For sample locations, see Fig. 1 and online Google map at http://www.jgeosci.org/157 

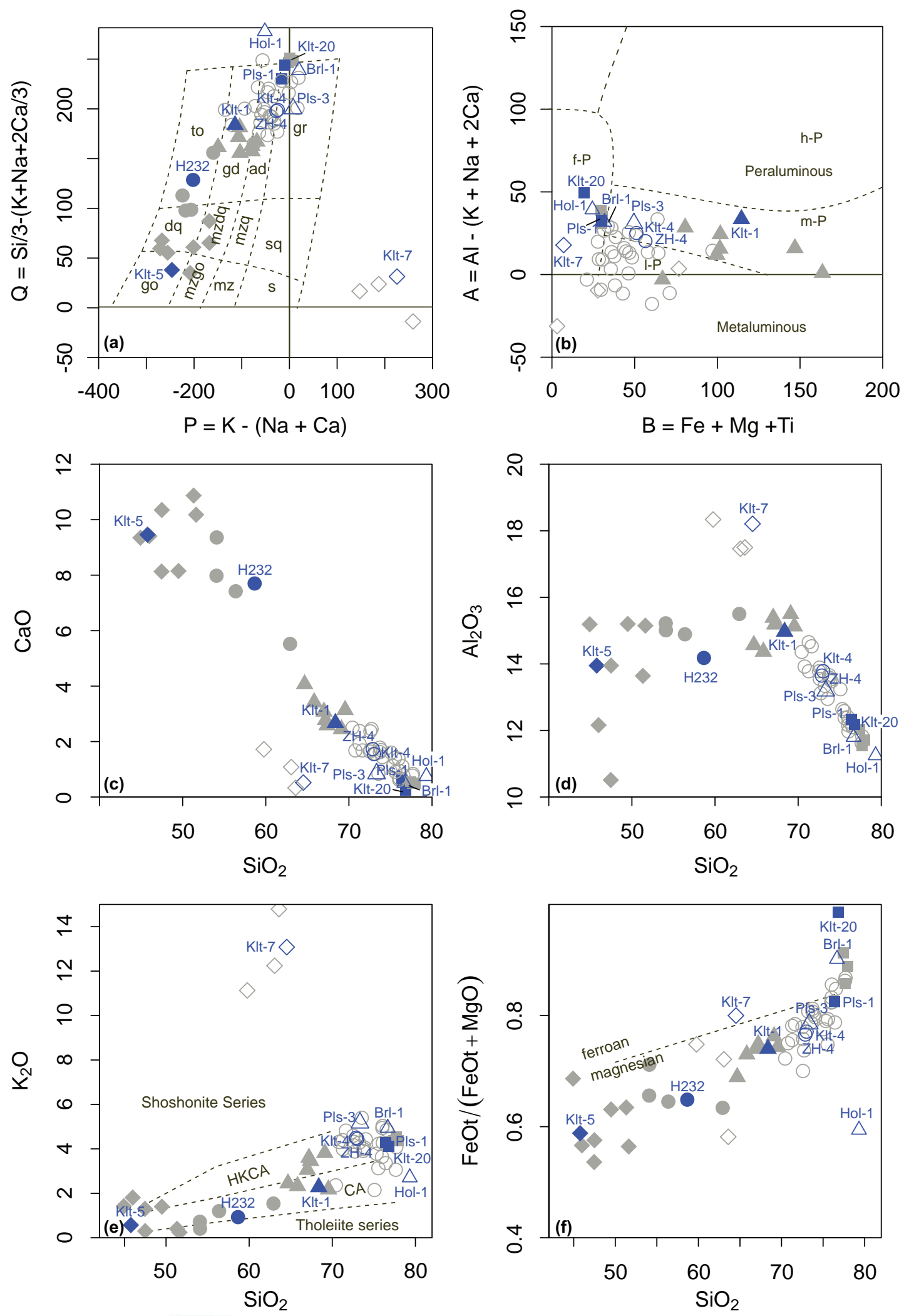

basic $\left(\mathrm{SiO}_{2}<52\right.$ wt. \%) felsic $\left(\mathrm{SiO}_{2}>70\right.$ wt. \%):

intermediate $\left(52<\mathrm{SiO}_{2}<63 \mathrm{wt}\right.$. \%) $\bigcirc$,ordinary' felsic granulites (type 1)

$\Delta$ transitional $\left(63<\mathrm{SiO}_{2}<70\right.$ wt. \%)

$\diamond$ hyperpotassic

residual granulites (type 2 ; HP partial melt loss)

$\triangle$ affected by partial de-alkalization in Q $\mathrm{Z}-$ Sill bands 
(52 $<\mathrm{SiO}_{2}<63$ wt. \%), transitional $\left(63<\mathrm{SiO}_{2}<70\right.$ wt. \%) and felsic $\left(\mathrm{SiO}_{2}>70\right.$ wt. \%, and thus belonging with the previous group to the acid rocks).

The available data span a range of compositions $\left(\mathrm{SiO}_{2}\right.$ $=44.9-79.3$ wt. \%) in the $\mathrm{P}-\mathrm{Q}$ diagram of Debon and Le Fort (1983, 1988), corresponding mainly to granite, adamellite and granodiorite, and to a lesser extent to tonalite, quartz diorite and gabbro (Fig. 2a). The trend observed in this diagram is calc-alkaline. The hyperpotassic granulites, rich in K-feldspar, have an exceptional composition, with values of $\mathrm{P}=\mathrm{K}-(\mathrm{Na}+\mathrm{Ca})>100$ and thus plotting to the right of the (quartz) syenite domain. The basic-intermediate samples are metaluminous (A/CNK down to 0.55 , see e.g. sample Klt-5). The acid granulites are mostly slightly peraluminous as shown by the B-A diagram of Debon and Le Fort $(1983,1988)$ modified by Villaseca et al. (1998) (Fig. 2b). The most peraluminous samples in our set are the very siliceous Klt-20 and Hol-1, followed by Pls-1 and Brl-1 (as argued below, all seem affected by a limited loss of alkalis to melt or fluid). There is a general tendency for a concomitant rise in $\mathrm{A} / \mathrm{CNK}$ and $\mathrm{SiO}_{2}$ values as well as an increase in $\mathrm{A}=$ $\mathrm{Al}-(\mathrm{K}+\mathrm{Na}+2 \mathrm{Ca})$ value with decreasing maficity (B $=\mathrm{Fe}+\mathrm{Mg}+\mathrm{Ti})$. The hyperpotassic granulites are felsic and metaluminous to subaluminous.

Harker plots for the calc-alkaline granulites are characterized by strong negative correlations of $\mathrm{SiO}_{2}$ with most oxides, such as $\mathrm{TiO}_{2}, \mathrm{FeO}, \mathrm{MgO}$ and $\mathrm{CaO}$, of which only the last is shown here as an example (Fig. 2c). The trend for $\mathrm{Al}_{2} \mathrm{O}_{3}$ displays a discontinuity at $\mathrm{SiO}_{2} \sim 70$ wt. \%, with an initial increase or little change for the more mafic (basic-transitional) compositions, and then a dramatic drop for the felsic granulites. As expected, the hyperpotassic granulites are $\mathrm{Al}_{2} \mathrm{O}_{3}$ rich. In the $\mathrm{SiO}_{2}-\mathrm{K}_{2} \mathrm{O}$ binary (after Peccerillo and Taylor 1976), the basic and

Fig. 2 Whole-rock major-element variation in the samples from the Blanský les granulite Massif (Janoušek et al. 2004, 2007, 2013 and unpublished data in grey, this work in blue). a - Multicationic P-Q plot (Debon and Le Fort 1983, 1988); $P$ represents the proportion of K-feldspar to plagioclase and $Q$ the quartz content (ad: adamellite; dq: quartz diorite, quartz gabbro, quartz anorthosite; gd: granodiorite; go: gabbro, diorite, anorthosite; gr: granite; mz: monzonite; mzdq: quartz monzodiorite; mzgo: monzogabbro, monzodiorite; mzq: quartz monzonite; s: syenite; sq: quartz syenite; to: tonalite, trondhjemite); b - Multicationic B-A plot of the same authors modified by Villaseca et al. (1998); $B$ represents the maficity and $A$ alumina saturation (l-P: low peraluminous, $\mathrm{m}-\mathrm{P}$ : moderately peraluminous, h-P: highly peraluminous, f-P: felsic peraluminous); note that only acid and hyperpotassic granulites are plotted; $\mathbf{c}$ - binary plot $\mathrm{SiO}_{2}-\mathrm{CaO}$ (wt. \%); $\mathbf{d}$ - binary plot $\mathrm{SiO}_{2}-\mathrm{Al}_{2} \mathrm{O}_{3}$ (wt. \%); e - binary plot $\mathrm{SiO}_{2}-\mathrm{K}_{2} \mathrm{O}$ (wt. \%) with the discrimination boundaries between the tholeiitic, calc-alkaline, high-K calc-alkaline and shoshonitic rocks of Peccerillo and Taylor (1976); f - diagram $\mathrm{SiO}_{2}$ (wt. \%) - FeOt/(FeOt + MgO) (Frost et al. 2001) to distinguish between the magnesian and ferroan associations. Note that this 'Fe number' is calculated from wt. \% and not from molecular proportions, which is a more common (and sensible) approach. intermediate granulites fall mainly into the (normal-K) calc-alkaline domain, the felsic types mostly in the high$\mathrm{K}$ calc-alkaline field, and the transitional types join the two trends. There is a general increase in the $\mathrm{K}_{2} \mathrm{O} / \mathrm{Na}_{2} \mathrm{O}$ ratios (by weight) with silica from basic-intermediate $(0.35 \pm 0.38$, median $\pm 1 \sigma)$, through transitional $(0.89 \pm$ $0.23)$, to the common (type 1) felsic granulites (1.29 \pm $0.42)$. This ratio is somewhat higher $(1.66 \pm 0.17)$ in the residual (type 2) granulites. Naturally, relatively low $\mathrm{SiO}_{2}$ and $\mathrm{CaO}$, as well as high $\mathrm{K}_{2} \mathrm{O}$ and $\mathrm{Al}_{2} \mathrm{O}_{3}$ contents characterize the hyperpotassic granulites, which are dominated by K-feldspar.

The relations of iron to magnesium are interesting, with $\mathrm{Fe}$ prevailing over $\mathrm{Mg}$, and $\mathrm{FeOt} / \mathrm{MgO}$ ratios increasing in the sequence basic-intermediate $(1.73 \pm$ $0.38)$, transitional $(2.87 \pm 0.28)$ and felsic granulites (3.70 \pm 1.08$)$. The residual type 2 granulites including Klt-20, have FeOt/MgO > 4.7. This is also true for partly de-alkalized granulite Brl-1, but the analogous sample Hol-1 is characterized by a low $\mathrm{FeOt} / \mathrm{MgO}$ of 0.78 . In a diagram of $\mathrm{FeOt} /(\mathrm{FeOt}+\mathrm{MgO})$ vs. $\mathrm{SiO}_{2}$ (after Frost et al. 2001), most of the analyses belong to the magnesian association, but samples at the very $\mathrm{SiO}_{2}$-rich end of the compositional spectrum enter the ferroan domain, which include the residual (type 2) granulites such as Klt-20 and the partly de-alkalized Brl-1.

\section{Petrology and P-T conditions}

The basic compositional characteristics of the studied samples are presented in a QAP diagram (Fig. 3) (Streckeisen 1976), using the calculated Catanorm proportions for each sample. In the following text, samples carrying eclogite-facies mineral assemblages and early decompressional reaction textures are described first, followed by those representing evidence for superimposed processes resulting in changes of rock composition.

\subsection{Relict eclogite-facies mineral assemblages and early decompressional reaction textures}

\subsubsection{Orthopyroxene-biotite-garnet granulite of granodiorite composition, Klt-1}

The rock has the following modal composition (wt. \%): 23.3 Qtz, 12.6 Kfs, 36.8 Pl, 20.8 Grt, 2.1 Opx, 3.0 Bt, 0.3 $\mathrm{Ilm}, 0.3 \mathrm{Rt}$. The locality is dominated by $\mathrm{S}_{2}$ structures, and the Klt-1 thin section shows penetrative mylonitic $S_{2}$ foliation (Fig. 4a).

Garnet is present in two generations, the older with $\sim 23$ mol. \% Grs and the younger with $~ 5 \%$ Grs. The latter grew by replacement of former kyanite. The sample 

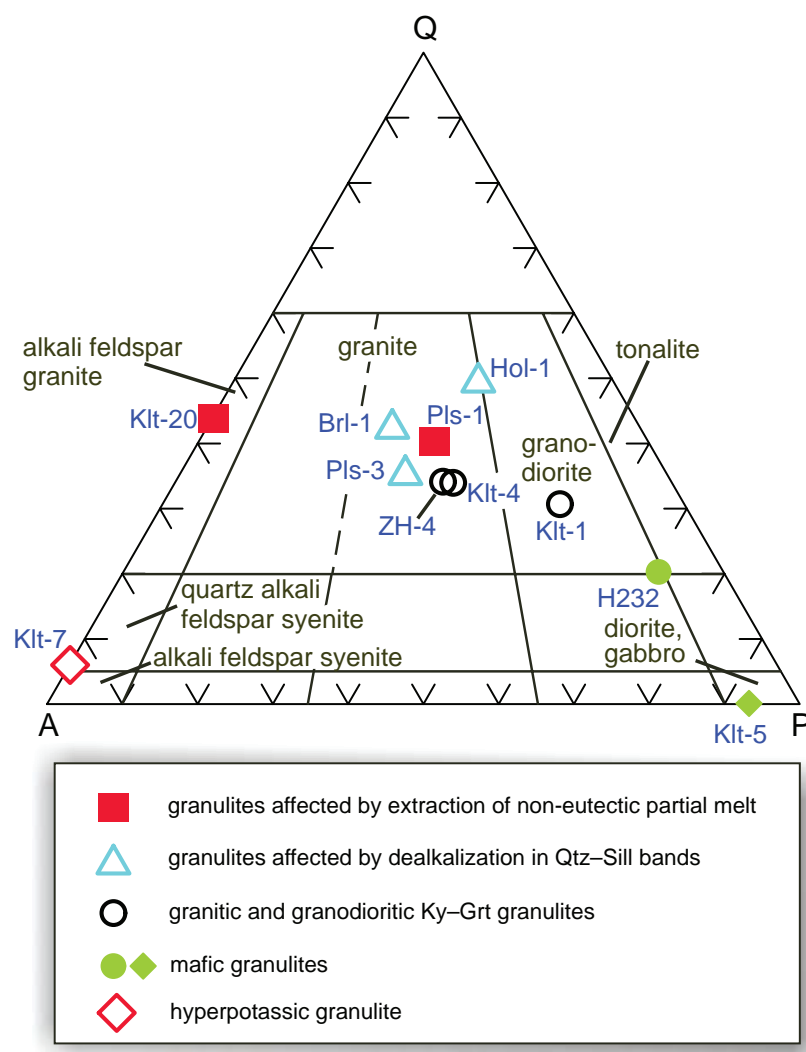

Fig. 3 The QAP diagram (Streckeisen 1976) for the studied rocks based on Catanorm calculation (Hutchison 1975; as implemented by GCDkit), recalculated to vol. \%.

exhibits several reaction textures that were not described previously in felsic granulites of the BLGM. Nevertheless, they are significant for petrological evaluation of granulite samples, particularly for calculations of their $\mathrm{P}-\mathrm{T}$ conditions.

\section{The assemblage Cpx + Grt I}

The assemblage Cpx + Grt I (Fig. 4b) in felsic granulite occurs in domains for which a pressure of 2.10-2.36 GPa was indicated by GASP barometry (Koziol and Newton 1988). It is uncertain whether the rare Cpx inclusions in Grt I were in chemical equilibrium with the GASP assemblage in the matrix. Possibly a later modification of Cpx composition by diffusion took place, resulting in its very low jadeite content (Tab. 2). Garnet I-Cpx thermometry indicates temperatures of $736-757^{\circ} \mathrm{C}$ (for $2.2 \mathrm{GPa}$ ). Garnet I- matrix biotite pairs yield $\mathrm{T}=890-1000^{\circ} \mathrm{C}$, but it is again uncertain whether the two phases were in equilibrium.

\section{Reaction garnet I $\rightarrow$ orthopyroxene + plagioclase}

Biotite-orthopyroxene thermometry yields $568-577^{\circ} \mathrm{C}$. Apparently, equilibration of the pair Bt-Opx took place relatively late during the cooling stage. Orthopyroxenebiotite-feldspars form localized mosaics and internally
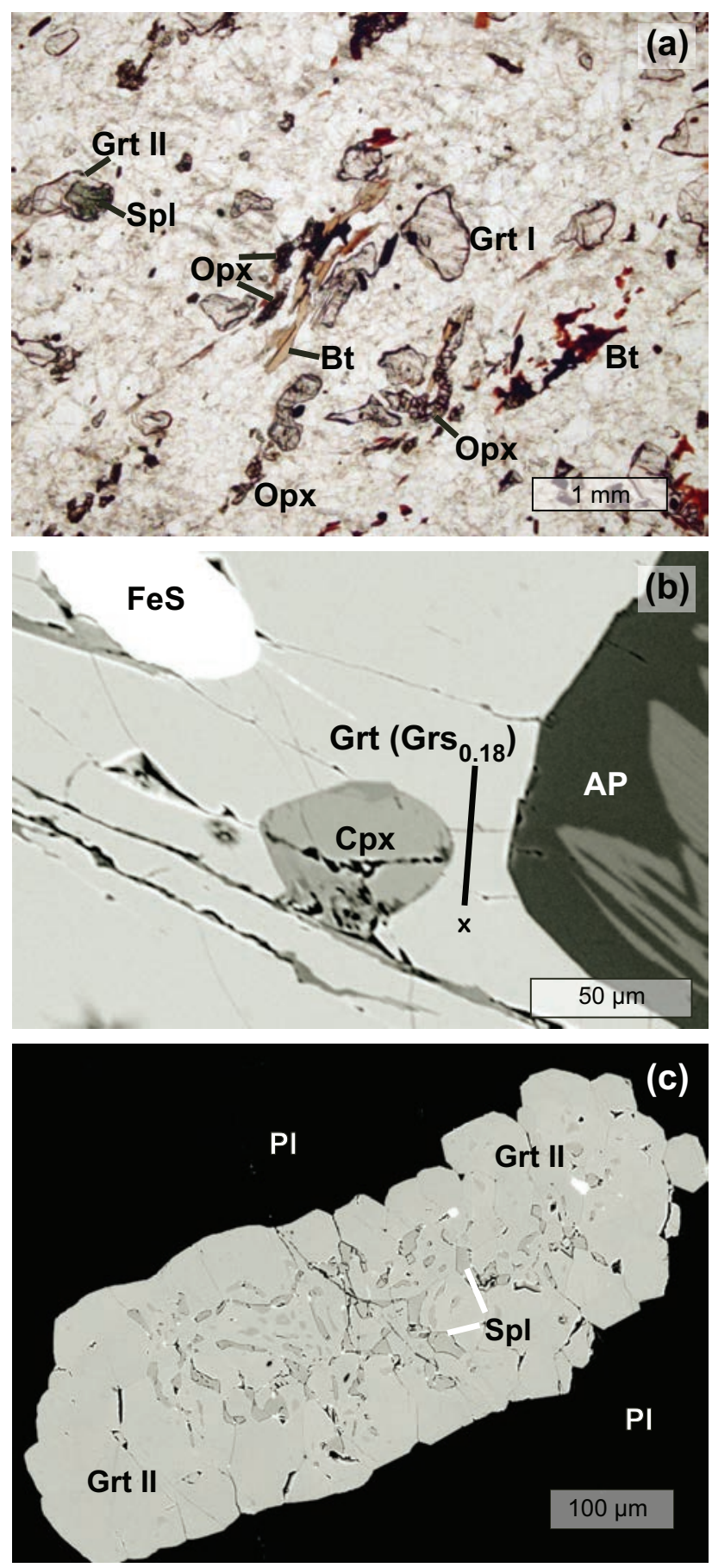

Fig. 4 Orthopyroxene-biotite-garnet granulite of granodiorite composition (Klt-1, near the summit of Mt. Klet'). a - Fabric of the rock with a strong foliation; $\mathbf{b}$ - Clinopyroxene inclusion in garnet I containing $18 \mathrm{~mol} . \%$ of the grossular component. Cpx is diopside with $6 \mathrm{~mol}$ \% Ca-Tschermak and minor jadeite, acmite and Ti-Tschermak molecules (2 to 3 mol. \%) (Tab. 2). Other inclusions in garnet are plagioclase with antiperthite (AP) and pyrrhotite (FeS); BSE. c - Garnet II in complete pseudomorph after kyanite, surrounded by a wide plagioclase (Pl) rim. Grt II contains numerous inclusions of Zn-bearing hercynitic spinel (slightly darker). Outer subhedral contour with concave forms indicates coalescence of numerous Grt crystals; BSE. 
appear to be an equilibrium assemblage in the $S_{2}$ fabric (Fig. 4a).

\section{Reaction kyanite + garnet I + biotite + plagioclase I $\rightarrow$ garnet II + spinel + plagioclase II}

The spectacular microstructures resulting from kyanite-consuming decompression reactions are notable in sample Klt-1. They are important for identifying the mode of generation of decompression-related garnet II in place of the former kyanite (Fig. 4c). Although no relict kyanite was observed in sample Klt-1, the process is reasonably inferred by analogy with a number of felsic granulite samples preserving intermediate stages of this reaction (e.g., see sample ZH-4 below).

\subsubsection{Kyanite-garnet granulite of granite composition with exceptionally well- -preserved early structures, Klt-4}

The rock consists of (wt. \%): $33.1 \mathrm{Qtz}, 30.0 \mathrm{Kfs}, 25.2 \mathrm{Pl}$, 8.6 Grt, $1.7 \mathrm{Ky}, 0.6 \mathrm{Bt}, 0.7$ Ap, 0.2 Rt. It is dominated by $\mathrm{S}_{1}$ structures with partial $\mathrm{S}_{2}$ overprint.

This compositionally homogeneous rock contains (meso-) perthite, quartz, and plagioclase plus euhedral garnet (23 mol. \% Grs), which is partly segregated into $\mathrm{mm}$ to $1 \mathrm{~cm}$ thick nearly monomineralic bands, and kyanite inclusions in large mesoperthite grains. A detailed compositional profile across such garnet was published by Franěk et al. (2011b), showing a flat uniform pattern through most of the grain with a decrease in $\mathrm{Ca}$ and increase in $\mathrm{Fe}$ at the rims, possibly caused by diffusion during exhumation (Fig. 5a). The main emphasis of previous studies from this locality $\mathrm{OH}^{*}$ - calculated was on evolution of the successive sets of deformation microstructures (Franěk et al. 2011b) and origin of the internal structure of perthitic Kfs crystals (Tajčmanová et al. 2012).

We have selected this sample for GASP barometry on perfectly preserved garnets hosting fairly large plagioclase inclusions, all being enclosed in mesoperthite porphyroclasts

Tab. 2 Electron-microprobe analyses of minerals in sample Klt-1

\begin{tabular}{|c|c|c|c|c|c|c|c|}
\hline Mineral & Grt I & Grt II & $\mathrm{Bt}$ & Opx & $\mathrm{Pl}$ & Spl & Cpx \\
\hline Analysis & 7 & 3 & 9 & 12 & 26 & 30 & 44 \\
\hline $\mathrm{SiO}_{2}$ & 38.60 & 38.80 & 37.44 & 51.45 & 63.36 & 0.05 & 51.45 \\
\hline $\mathrm{TiO}_{2}$ & 0.12 & 0.01 & 5.67 & 0.12 & 0.00 & 0.03 & 0.71 \\
\hline $\mathrm{Al}_{2} \mathrm{O}_{3}$ & 21.58 & 21.48 & 14.19 & 1.39 & 22.53 & 61.23 & 4.05 \\
\hline $\mathrm{Cr}_{2} \mathrm{O}_{3}$ & 0.01 & 0.02 & 0.03 & 0.00 & 0.00 & 0.13 & 0.07 \\
\hline $\mathrm{FeO}$ & 25.82 & 29.61 & 16.64 & 28.67 & 0.17 & 24.59 & 8.12 \\
\hline $\mathrm{MnO}$ & 0.49 & 0.60 & 0.02 & 0.23 & 0.00 & 0.07 & 0.05 \\
\hline $\mathrm{MgO}$ & 6.26 & 7.52 & 12.45 & 18.51 & 0.00 & 10.75 & 13.32 \\
\hline $\mathrm{CaO}$ & 7.92 & 2.94 & 0.00 & 0.19 & 4.23 & 0.02 & 22.46 \\
\hline $\mathrm{Na}_{2} \mathrm{O}$ & 0.05 & 0.04 & 0.03 & 0.02 & 9.17 & & 0.60 \\
\hline $\mathrm{K}_{2} \mathrm{O}$ & & & 9.26 & 0.02 & 0.15 & & 0.00 \\
\hline $\mathrm{BaO}$ & & & 0.30 & & & & \\
\hline $\mathrm{V}_{2} \mathrm{O}_{3}$ & & & & & & 0.24 & \\
\hline $\mathrm{ZnO}$ & & & & & & 4.43 & \\
\hline F & & 0.03 & 0.68 & & & & 0.07 \\
\hline $\mathrm{O}=\mathrm{F}, \mathrm{Cl}$ & & & -0.29 & & & & \\
\hline Total & 100.85 & 101.05 & 96.42 & 100.60 & 99.61 & 101.54 & 100.90 \\
\hline
\end{tabular}

Atoms per given number of oxygen atoms

\begin{tabular}{|c|c|c|c|c|c|c|c|}
\hline $\mathrm{O}$ & 12 & 12 & 20 & 6 & 5 & 4 & 6 \\
\hline$\overline{\mathrm{Si}}$ & 2.975 & 2.994 & 5.599 & 1.960 & 2.814 & 0.001 & 1.899 \\
\hline $\mathrm{Al}^{\mathrm{iv}}$ & 0.025 & 0.006 & 2.401 & & 1.180 & & 0.176 \\
\hline $\mathrm{Al}^{\mathrm{vi}}$ & 1.940 & 1.951 & 0.100 & 0.062 & & 1.922 & \\
\hline $\mathrm{Ti}$ & 0.007 & 0.001 & 0.638 & 0.003 & - & 0.001 & 0.020 \\
\hline $\mathrm{Cr}$ & 0.001 & 0.001 & 0.004 & 0.000 & - & 0.003 & 0.002 \\
\hline $\mathrm{Fe}^{3+}$ & 0.047 & 0.042 & & 0.014 & & 0.074 & 0.027 \\
\hline $\mathrm{Fe}^{2+}$ & 1.618 & 1.869 & 2.081 & 0.899 & 0.006 & 0.473 & 0.224 \\
\hline $\mathrm{Mn}$ & 0.032 & 0.039 & 0.003 & 0.007 & & 0.002 & 0.002 \\
\hline $\mathrm{Mg}$ & 0.719 & 0.865 & 2.776 & 1.051 & & 0.427 & 0.733 \\
\hline $\mathrm{Ni}$ & 0.000 & 0.000 & 0.004 & 0.000 & - & & \\
\hline $\mathrm{Zn}$ & 0.000 & 0.000 & 0.001 & - & - & 0.087 & \\
\hline $\mathrm{Ca}$ & 0.654 & 0.243 & 0.000 & 0.008 & 0.201 & 0.001 & 0.888 \\
\hline $\mathrm{Na}$ & & & 0.010 & 0.001 & 0.790 & 2.991 & 0.043 \\
\hline K & & & 1.766 & 0.001 & 0.008 & & 0.000 \\
\hline $\mathrm{Ba}$ & & & 0.018 & & & & \\
\hline $\mathrm{OH}^{*}$ & & & 3.676 & & & & \\
\hline $\mathrm{F}$ & & & 0.322 & & & & \\
\hline $\mathrm{Cl}$ & & & 0.003 & & & & \\
\hline Total & 8.018 & 8.011 & 19.402 & 4.006 & 1.873 & 2.991 & 4.014 \\
\hline \multicolumn{8}{|c|}{ End-members (mol. \%) } \\
\hline Almandine & 52.76 & 61.68 & & & An 20.1 & & \\
\hline Andradite & 2.35 & 2.11 & & & Ab 79.0 & & \\
\hline Grossular & 19.60 & 5.95 & & & Or 0.9 & & \\
\hline Pyrope & 24.18 & 28.89 & & & & & \\
\hline Spessartine & 1.08 & 1.31 & & & & & \\
\hline Uvarovite & 0.03 & 0.06 & & & & & \\
\hline
\end{tabular}

Cpx 44: acmite $3 \%$, jadeite $2 \%$, Ca-tschermak $6 \%$, Ti-tschermak $2 \%$. 

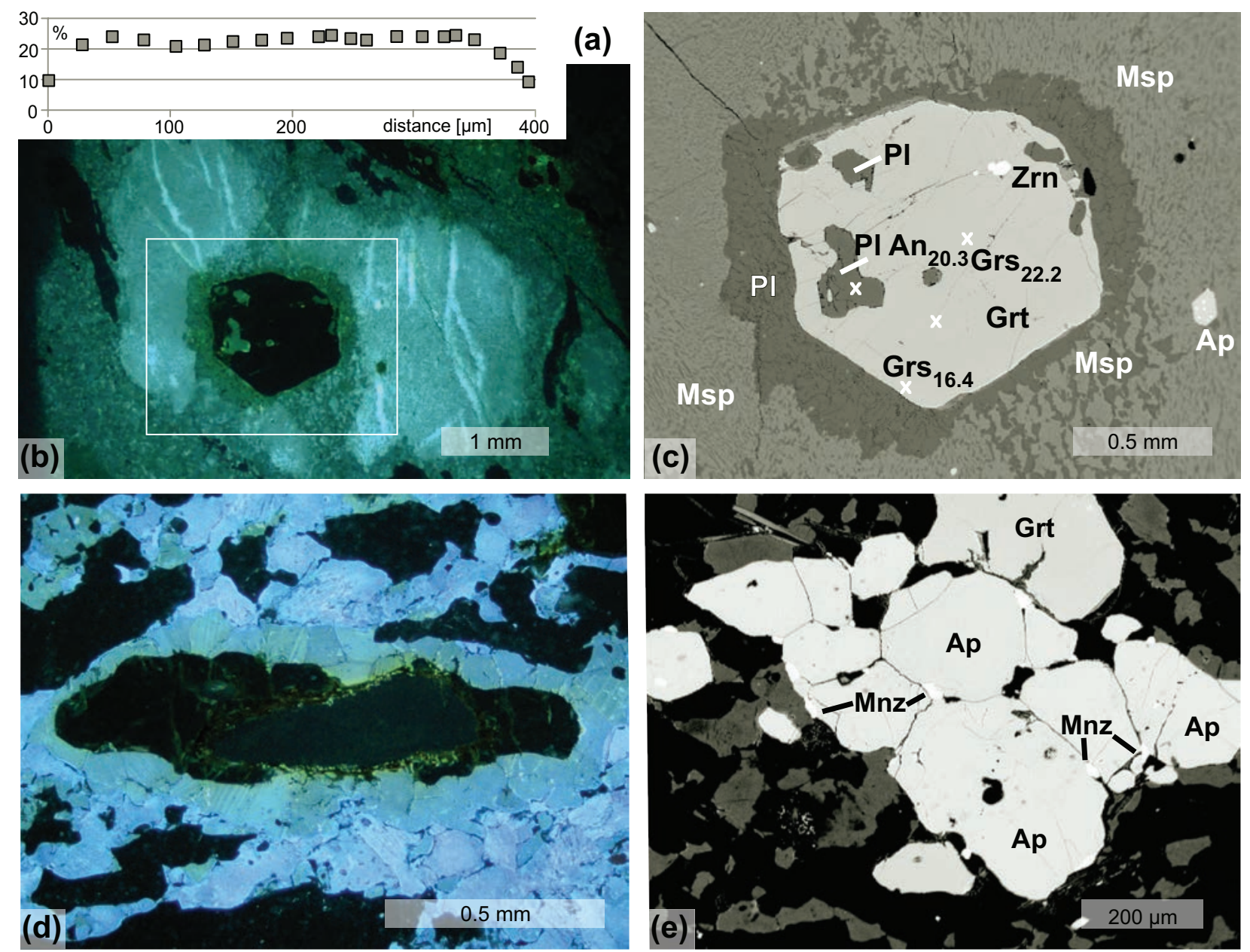

Fig. 5 Kyanite-garnet felsic (type 1) granulite with exceptionally well-preserved early structures from slopes of Mt. Klet'. a - Grs profile (mol. \%) across a $400 \mu \mathrm{m}$ large euhedral garnet I inclusion in perthite from $\mathrm{S}_{1}$ fabric, locality the same as sample Klt-4. Data adopted from Franěk et al. (2011b). b - Optical cathodoluminescence image of a large mesoperthite porphyroclast, surrounded by a feldspar-quartz mosaic, quartz ribbons and young small garnet crystals of the second generation. The mesoperthite encloses a subhedral Grt I crystal (see the next BSE image for its detail). Sample Klt-4. c - Subhedral Grt I with plagioclase rim (Pl), carrying plagioclase and zircon (Zrn) inclusions, enclosed in a large mesoperthite porphyroclast. Mol. \% grossular near centre $\left(\mathrm{Grs}_{22.2}\right)$ and at rim $\left(\mathrm{Grs}_{16.4}\right)$ are indicated. Mol. \% anorthite in Pl inclusion is also shown $\left(\mathrm{An}_{20.3}\right)$; BSE. d - Optical cathodoluminescence image of a subhedral kyanite parallel to penetrative $\mathrm{S}_{2}$ foliation. Kyanite is partly overgrown by Grt II, all together enclosed in plagioclase rim. Sample H261. e - Cluster of relatively coarse anhedral apatite I with minute unmixed monazite. Adjacent garnet is also seen. Sample H296-AF near Klt-4, BSE.

(Fig. 5b-c, Tab. 3). The pressure estimate using Koziol and Newton (1988) barometry is $2.24 \mathrm{GPa}$ (for $950^{\circ} \mathrm{C}$ ), a value notably higher than that obtained from this locality by the pseudosection method (1.6-1.8 GPa) (Franěk et al. 2011b). Relict kyanite surrounded by plagioclase rim is illustrated in Fig. 5d. Examples of kyanite inclusions in large mesoperthite crystals indicate that the assemblage Grt I + Ky + $\mathrm{Pl}$ inclusions in Grt I + mesoperthite was at equilibrium during the HP-HT stage. The near-peak temperatures of these granulites at $900-950^{\circ} \mathrm{C}$ were determined previously by Tajčmanová et al. (2012) by means of two-feldspar thermometry based on experiments of Benisek et al. (2010).
In addition, sample H296-AF, taken from the same outcrop as Klt-4, carries two contrasting morphological types of apatite. The main population forms relatively large, anhedral grains with abundant extragranular monazite (Fig. 5e). The other type of apatite is much smaller and forms euhedral, acicular crystals. As apatite is a notably refractory mineral, the younger generation probably crystallized by an additive process, likely due to the liberation of phosphorus by unmixing and recrystallization of the large feldspar porphyroclasts during $\mathrm{S}_{2}$ development. Apatite II (Tab. 4) has lower $\mathrm{FeO}$ and $\mathrm{MgO}$ contents and higher REE than apatite I. 


\subsubsection{Complete decompression conversion of kyanite-bearing felsic granulite of granite composition to orthopyroxene- biotite-garnet II charnockitic granulite, $\mathrm{ZH}-4$}

The rock has the following modal composition (wt. \%): 32.7 Qtz, 28.7 Kfs, 28.8 Pl, 7.1 Grt, 1.8 Ky, 2.1 Bt, 0.3 Ilm, and accessory Ap and Rt (Tab. 5). The sample shows relict $S_{1}$ foliation strongly overprinted by $S_{2}$ cleavage. A pressure estimate of $2.30 \mathrm{GPa}$ at $1000^{\circ} \mathrm{C}$ is obtained by GASP barometry, utilizing garnet I core composition (Grs 21.5 mol. \%) and a large plagioclase inclusion.

Microscopic study of 15 thin sections from the quarry reveals that the samples preserve various stages of transformation of the original Ky-Grt I felsic granulite to orthopyroxene-garnet charnockite ( \pm biotite). Details of kyanite-consuming reactions at this locality were also studied by Štípská et al. (2010). Intermediate stages show a progressive replacement of kyanite by plagioclase, spinel and garnet II (Fig. 6a-d). As a regular feature of these reactions, orthopyroxene enters the decompression assemblage only after kyanite is consumed and spinel is mantled by garnet II. During quarry operations, charnockite domains $c$. 2-3 m across were seen thanks to a brownish-grey coloration that contrasted with white enclosing granulite. This mode of occurrence of charnockitic granulites is another example of patchwork-like processes in the BLGM.

\subsection{Hyperpotassic granulites}

Hyperpotassic granulites that occur as meter-scale deformed bodies at the Plešovice quarry were described as a new rock type in the BLGM twenty-five years ago (Vrána 1989, 2011). Later a small occurrence of
Tab. 3 Electron-microprobe analyses of minerals in sample Klt-4

\begin{tabular}{|c|c|c|c|c|c|c|c|}
\hline Mineral & Grt I core & Grt I rim & Grt II & $\mathrm{Pl}$ & $\mathrm{Bt}$ & Ilm & Rt \\
\hline Analysis & 1 & 3 & 50 & 4 & 35 & 33 & 28 \\
\hline $\mathrm{SiO}_{2}$ & 38.75 & 38.84 & 38.84 & 64.56 & 37.38 & 0.05 & 0.02 \\
\hline $\mathrm{TiO}_{2}$ & 0.15 & 0.44 & 0.03 & 0.00 & 3.97 & 53.21 & 99.14 \\
\hline $\mathrm{Al}_{2} \mathrm{O}_{3}$ & 21.71 & 21.56 & 21.72 & 22.63 & 16.51 & 0.00 & 0.02 \\
\hline $\mathrm{Cr}_{2} \mathrm{O}_{3}$ & 0.00 & 0.00 & 0.02 & 0.00 & 0.06 & 0.08 & 0.10 \\
\hline $\mathrm{FeOt}$ & 24.44 & 26.46 & 28.64 & 0.20 & 15.76 & 42.98 & 0.24 \\
\hline $\mathrm{MnO}$ & 0.36 & 0.39 & 0.39 & 0.00 & 0.06 & 0.19 & 0.00 \\
\hline $\mathrm{MgO}$ & 6.35 & 6.70 & 7.71 & 0.00 & 12.73 & 0.23 & 0.00 \\
\hline $\mathrm{CaO}$ & 8.44 & 6.19 & 2.91 & 4.28 & 0.02 & 0.02 & 0.00 \\
\hline $\mathrm{Na}_{2} \mathrm{O}$ & 0.00 & 0.00 & 0.00 & 8.83 & 0.06 & & \\
\hline $\mathrm{K}_{2} \mathrm{O}$ & & & 0.01 & 0.69 & 9.42 & & \\
\hline $\mathrm{BaO}$ & & & & & 0.12 & & \\
\hline $\mathrm{V}_{2} \mathrm{O}_{3}$ & & & 0.03 & & 0.06 & 0.13 & 0.39 \\
\hline $\mathrm{P}_{2} \mathrm{O}_{5}$ & & & 0.04 & & & & \\
\hline $\mathrm{ZnO}$ & & & & & 0.00 & 0.22 & 0.01 \\
\hline $\mathrm{Nb}_{2} \mathrm{O}_{5}$ & & & & & & 0.15 & 0.71 \\
\hline $\mathrm{ZrO}_{2}$ & & & & & & & 0.22 \\
\hline
\end{tabular}

\begin{tabular}{lllllrrr}
$\mathrm{F}$ & \multicolumn{7}{c}{0.52} \\
\hline Total & 100.20 & 100.58 & 100.34 & 101.19 & 96.67 & 97.25 & 100.85
\end{tabular}

Atoms per given number of oxygen atoms

\begin{tabular}{|c|c|c|c|c|c|c|c|}
\hline $\mathrm{O}$ & 12 & 12 & 12 & 8 & 22 & 3 & 2 \\
\hline $\mathrm{Si}$ & 2.990 & 2.994 & 3.005 & 2.832 & 5.542 & 0.001 & 0.000 \\
\hline $\mathrm{Al}^{\mathrm{iv}}$ & 0.010 & 0.006 & 0.000 & 1.170 & 2.458 & 0.000 & 0.000 \\
\hline $\mathrm{Al}^{\mathrm{vi}}$ & 1.967 & 1.955 & 1.981 & & 0.427 & & \\
\hline $\mathrm{Ti}$ & 0.009 & 0.026 & 0.002 & & 0.443 & 1.045 & 0.996 \\
\hline $\mathrm{Cr}$ & 0.000 & 0.000 & 0.001 & & 0.007 & 0.002 & 0.001 \\
\hline $\mathrm{Fe}^{3+}$ & 0.022 & 0.017 & 0.009 & & & 0.000 & 0.003 \\
\hline $\mathrm{Fe}^{2+}$ & 1.555 & 1.689 & 1.844 & 0.007 & 1.954 & 0.939 & \\
\hline Mn & 0.024 & 0.025 & 0.026 & & 0.008 & 0.004 & \\
\hline Mg & 0.730 & 0.770 & 0.889 & & 2.813 & 0.009 & \\
\hline $\mathrm{Ca}$ & 0.698 & 0.511 & 0.241 & 0.201 & 0.003 & 0.001 & \\
\hline $\mathrm{Na}$ & & & & 0.751 & 0.023 & & \\
\hline K & & & & 0.039 & 1.781 & & \\
\hline $\mathrm{F}$ & & & & & 0.244 & & \\
\hline $\mathrm{OH}^{*}$ & & & & & 3.756 & & \\
\hline Total & 8.005 & 7.993 & 7.998 & 5.000 & 19.459 & 2.001 & 1.000 \\
\hline \multicolumn{8}{|c|}{ End-members (mol. \%) } \\
\hline Almandine & 51.45 & 55.92 & 61.30 & An 20.1 & & & \\
\hline Andradite & 1.09 & 0.88 & 0.48 & Ab 79.1 & & & \\
\hline Grossular & 22.24 & 16.37 & 7.54 & Or 0.8 & & & \\
\hline Pyrope & 24.43 & 25.97 & 29.77 & & & & \\
\hline Spessartine & 0.79 & 0.86 & 0.86 & & & & \\
\hline Uvarovite & 0.00 & 0.00 & 0.06 & & & & \\
\hline
\end{tabular}

hyperpotassic granulite was discovered near the village of Lhotka in the south-central part of the BLGM (Vrána 1998). Recently, an exceptionally large body (c. $200 \times$ $45 \mathrm{~m}$ ) of Grt-bearing hyperpotassic granulite was discovered in the forest at Kokotín on Mt. Klet' ridge (Janoušek et al. 2013). Hyperpotassic granulites have the composition of potassic alkali feldspar syenite (Fig. 3; Tab. 6) and consist predominantly of K-feldspar, with either minor Grt (Plešovice and Kokotín; designated as the Plešovice type) or Di (Lhotka type), and accessory zircon and apatite; no primary plagioclase is found. Quartz is pres- 
Tab. 4 Electron-microprobe analyses of apatite I and apatite II in sample H296-AF

\begin{tabular}{|c|c|c|c|c|c|}
\hline Analysis & 7 & 6 & & 7 & 6 \\
\hline Generation & Ap I & Ap II & & Ap I & Ap II \\
\hline $\mathrm{SiO}_{2}$ & 0.07 & 0.24 & $\mathrm{La}_{2} \mathrm{O}_{3}$ & 0.05 & 0.19 \\
\hline $\mathrm{Al}_{2} \mathrm{O}_{3}$ & 0.00 & 0.01 & $\mathrm{Ce}_{2} \mathrm{O}_{3}$ & 0.15 & 0.70 \\
\hline FeOt & 0.46 & 0.12 & $\mathrm{Nd}_{2} \mathrm{O}_{3}$ & 0.25 & 0.60 \\
\hline $\mathrm{MnO}$ & 0.03 & 0.01 & $\mathrm{Sm}_{2} \mathrm{O}_{3}$ & 0.11 & 0.11 \\
\hline $\mathrm{MgO}$ & 0.31 & 0.01 & $\mathrm{Pr}_{2} \mathrm{O}_{3}$ & 0.05 & 0.09 \\
\hline $\mathrm{CaO}$ & 54.78 & 53.99 & $\mathrm{Gd}_{2} \mathrm{O}_{3}$ & 0.02 & 0.12 \\
\hline $\mathrm{SrO}$ & 0.00 & 0.00 & $\mathrm{Dy}_{2} \mathrm{O}_{3}$ & 0.00 & 0.01 \\
\hline $\mathrm{PbO}$ & 0.02 & 0.00 & $\mathrm{Y}_{2} \mathrm{O}_{3}$ & 0.02 & 0.02 \\
\hline $\mathrm{Na}_{2} \mathrm{O}$ & 0.11 & 0.24 & $\mathrm{ThO}_{2}$ & 0.00 & 0.00 \\
\hline $\mathrm{P}_{2} \mathrm{O}_{5}$ & 40.44 & 39.45 & $\mathrm{UO}_{2}$ & 0.00 & 0.00 \\
\hline $\mathrm{SO}_{3}$ & 0.00 & 0.01 & $\mathrm{O}=\mathrm{F}$ & -1.54 & -1.44 \\
\hline $\mathrm{F}$ & 3.66 & 3.41 & $\mathrm{O}=\mathrm{Cl}$ & -0.03 & -0.02 \\
\hline $\mathrm{Cl}$ & 0.15 & 0.09 & Total & 99.11 & 97.94 \\
\hline
\end{tabular}

ent only in a minority of samples. Hyperpotassic granulites were interpreted as a product of HP non-eutectic melting, followed by $<40$ \% HP-HT fractional crystallization of an assemblage dominated by garnet, apatite and zircon with, or without, some crystal accumulation (Vrána 1989; Janoušek et al. 2007). Worth noting is that hyperpotassic granulites both at Plešovice and Kokotín are spatially associated siliceous types of Ky-rich granulite, designated in the following section as residual (type 2) granulites (Fig. 7a).

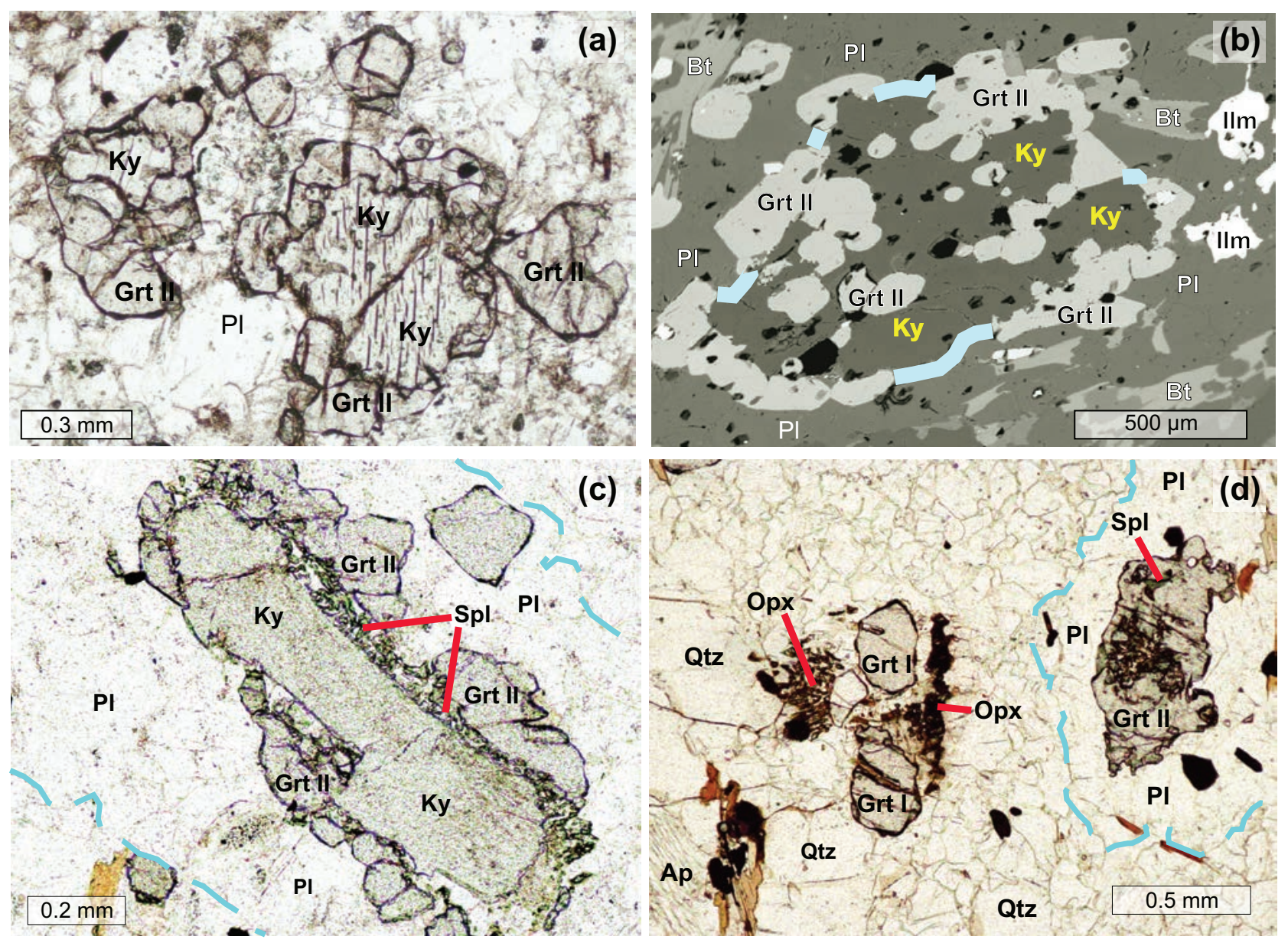

Fig. 6 Complete decompression conversion of Ky-Grt I in felsic granulite to Opx-Bt-Grt II charnockitic granulite. a - Kyanite overgrown by Grt II. Sample ZH-4, Zrcadlová Hut' quarry, PPL. b - Kyanite crystal is overgrown and both marginally and internally partly replaced by newly formed Grt II. Kyanite interface with enclosing Pl rim is indicated by blue line. Sample ZH-4, BSE; c - Relict kyanite crystal overgrown by narrow hercynitic spinel rim (Spl), a wider zone of garnet II (Grt II) and outer plagioclase rim (outline of which is indicated by the dashed blue line). Sample LV93B, PPL; d - Orthopyroxene-garnet charnockite representing final stage of decompression-related metamorphism in $\mathrm{S}_{2}$ fabric; garnet I (Grt I) partly reacted to orthopyroxene and plagioclase, garnet II with spinel inclusions is mantled by wide plagioclase rim (outline of which is indicated by the dashed blue line). The domain of Grt II with Spl and Pl rim developed via replacement of kyanite. Sample LV107, PPL. 


\subsection{Kyanite-rich residual (type 2) felsic granulites}

\subsubsection{Kyanite-garnet felsic granulite, Pls-1}

The rock is composed of (wt. \%) $39.4 \mathrm{Qtz}, 28.4 \mathrm{Kfs}, 25.6$ Pl, 4.4 Grt, 1.3 Ky, 0.9 Bt, 0.1 Ap and < 0.1 Rt (Tab. 7). This part of the Plešovice quarry is dominated by $\mathrm{S}_{3}$ structures with relics of $\mathrm{S}_{2}$.

Sample Pls-1 is similar to a group of four highsilica kyanite-garnet felsic granulite samples from the same locality analysed previously (Strejček 1986). Specific features of this rock are the absence of plagioclase rims around kyanite (Fig. 7b), low Ca content in garnet $(7.7 \mathrm{~mol}$. $\%$ Grs in the core) (Tab. 7), and Ca-poor plagioclase (normative $\mathrm{An}_{08}$ ). The original mesoperthite is largely recrystallized to finegrained mosaics of K-feldspar and sodic plagioclase; quartz is transformed to platy grains. Kyanite is rarely inverted to sillimanite. Accessory biotite parallel to foliation is probably of retrograde origin.

Pressures of $2.06 \mathrm{GPa}$ (at $900^{\circ} \mathrm{C}$ ) or $2.32 \mathrm{GPa}$ (at $1000^{\circ} \mathrm{C}$ ) were obtained from GASP barometry, using the compositions of garnet core and a large plagioclase inclusion (130 $\mu \mathrm{m}$ in diameter) in the subhedral garnet (Fig. 7c). A calculation using the same $\mathrm{Pl}$ analysis and Grt rim (No. 110, Tab. 7) yields a pressure of 1.65 $\mathrm{GPa}$ at $1000^{\circ} \mathrm{C}$. The Grt rim composition is considered to reflect severe $\mathrm{Ca}$ depletion.

It is suggested that the low Ca-content in this rock was such that sufficient Ca could not be mobilized to sites of potential formation of plagioclase rims around kyanite. Also, given the relatively low Grs content in garnet, decompression breakdown of garnet to plagioclase + orthopyroxene rims did not take place. As a result of this Ca-poor and anhydrous composition the rock
Tab. 5 Electron-microprobe analyses of minerals in sample ZH-4

\begin{tabular}{|c|c|c|c|c|c|c|c|}
\hline Mineral & Grt I & Grt II & $\mathrm{Pl}$ & $\mathrm{Pl}$ & $\mathrm{Bt}$ & Ky & Ilm \\
\hline Analysis & 21 & 12 & 20 & 22 & 16 & 11 & 18 \\
\hline $\mathrm{SiO}_{2}$ & 38.18 & 38.21 & 62.62 & 58.91 & 37.34 & 37.15 & 0.01 \\
\hline $\mathrm{TiO}_{2}$ & 0.10 & 0.03 & & & 4.02 & 0.04 & 52.73 \\
\hline $\mathrm{Al}_{2} \mathrm{O}_{3}$ & 21.34 & 20.89 & 22.85 & 25.48 & 16.68 & 62.67 & 0.00 \\
\hline $\mathrm{Cr}_{2} \mathrm{O}_{3}$ & 0.00 & 0.03 & & & 0.07 & 0.02 & 0.02 \\
\hline $\mathrm{FeOt}$ & 25.97 & 30.97 & 0.02 & 0.15 & 12.12 & 0.21 & 44.94 \\
\hline $\mathrm{MnO}$ & 0.44 & 0.50 & & & 0.05 & 0.01 & 0.12 \\
\hline $\mathrm{MgO}$ & 5.40 & 6.71 & & & 15.30 & 0.04 & 0.83 \\
\hline $\mathrm{CaO}$ & 8.34 & 2.46 & 4.64 & 7.50 & 0.04 & 0.00 & 0.00 \\
\hline $\mathrm{Na}_{2} \mathrm{O}$ & 0.03 & 0.02 & 8.62 & 7.39 & 0.07 & 0.00 & \\
\hline $\mathrm{K}_{2} \mathrm{O}$ & 0.01 & 0.00 & 0.27 & 0.33 & 9.59 & 0.00 & 0.00 \\
\hline $\mathrm{BaO}$ & & & & & 0.15 & & \\
\hline $\mathrm{P}_{2} \mathrm{O}_{5}$ & 0.06 & 0.02 & 0.03 & 0.06 & & & \\
\hline $\mathrm{Y}_{2} \mathrm{O}_{3}$ & 0.03 & 0.00 & & & & & \\
\hline $\mathrm{V}_{2} \mathrm{O}_{3}$ & 0.01 & 0.05 & & & 0.19 & 0.01 & 0.14 \\
\hline $\mathrm{Nb}_{2} \mathrm{O}_{5}$ & & & & & & & 0.10 \\
\hline $\mathrm{F}$ & 0.05 & 0.06 & & & 2.07 & 0.03 & \\
\hline Total & 99.96 & 99.95 & 99.05 & 99.82 & 97.69 & 100.18 & 98.89 \\
\hline
\end{tabular}

Atoms per given number of oxygen atoms

\begin{tabular}{|c|c|c|c|c|c|c|c|}
\hline $\mathrm{O}$ & 12 & 12 & 8 & 8 & 22 & 5 & 3 \\
\hline$S i$ & 2.983 & 3.003 & 2.806 & 2.633 & 5.491 & 1.000 & 0.000 \\
\hline $\mathrm{Al}^{\text {iv }}$ & 0.017 & 0.000 & 1.207 & 1.343 & 2.509 & 1.988 & 0.000 \\
\hline $\mathrm{Al}$ vi & 1.952 & 1.939 & & & 0.382 & & \\
\hline $\mathrm{Ti}$ & 0.006 & 0.002 & & & 0.445 & 0.001 & 1.008 \\
\hline $\mathrm{Cr}$ & 0.001 & 0.001 & & & 0.008 & & 0.002 \\
\hline $\mathrm{Fe}^{3+}$ & 0.037 & 0.049 & 0.000 & 0.006 & & 0.005 & 0.000 \\
\hline $\mathrm{Fe}^{2+}$ & 1.660 & 1.987 & 0.001 & 0.000 & 1.491 & & 0.955 \\
\hline $\mathrm{Mn}$ & 0.029 & 0.033 & & & 0.006 & & 0.003 \\
\hline $\mathrm{Mg}$ & 0.629 & 0.786 & & & 3.354 & 0.002 & 0.031 \\
\hline $\mathrm{Ca}$ & 0.698 & 0.207 & 0.223 & 0.359 & 0.006 & & 0.000 \\
\hline $\mathrm{Na}$ & & & 0.749 & 0.640 & 0.020 & & 0.000 \\
\hline K & & & 0.015 & 0.019 & 1.799 & & 0.001 \\
\hline $\mathrm{Ba}$ & & & & & 0.009 & & \\
\hline $\mathrm{F}$ & & & & & 0.963 & 0.003 & \\
\hline $\mathrm{OH}^{*}$ & & & & & 3.037 & & \\
\hline Total & 8.012 & 8.007 & 5.001 & 5.000 & 19.520 & 2.999 & 2.000 \\
\hline \multicolumn{8}{|c|}{ End-members (mol. \%) } \\
\hline Almandine & 54.53 & 65.53 & An 22.6 & An 35.3 & & & \\
\hline Andradite & 1.85 & 2.48 & Ab 75.9 & Ab 62.9 & & & \\
\hline Grossular & 21.51 & 4.41 & Or 1.6 & Or 1.8 & & & \\
\hline Pyrope & 21.10 & 26.40 & & & & & \\
\hline Spessartine & 0.98 & 1.12 & & & & & \\
\hline Uvarovite & 0.03 & 0.06 & & & & & \\
\hline
\end{tabular}


Tab. 6 Whole-rock composition of hyperpotassic and corresponding residual (type 2) granulites

\begin{tabular}{lrrrr}
\hline & \multicolumn{2}{c}{ Kokotín } & \multicolumn{2}{c}{ Plešovice } \\
Sample & ${\text { Klt- } 7^{\dagger}}$ & \multicolumn{1}{c}{ Klt-20 } & 1/VS89 & \multicolumn{1}{c}{ Pls-1 } \\
\hline wt. \% & & & & \\
$\mathrm{SiO}_{2}$ & 64.52 & 76.81 & 61.18 & 76.34 \\
$\mathrm{TiO}_{2}$ & 0.07 & 0.05 & 0.07 & 0.08 \\
$\mathrm{Al}_{2} \mathrm{O}_{3}$ & 18.21 & 12.18 & 17.86 & 12.34 \\
$\mathrm{FeOt}$ & 0.40 & 1.45 & 0.89 & 1.60 \\
$\mathrm{MnO}$ & 0.01 & 0.02 & 0.04 & 0.05 \\
$\mathrm{MgO}$ & 0.10 & 0.08 & 0.28 & 0.34 \\
$\mathrm{CaO}$ & 0.52 & 0.26 & 1.79 & 0.61 \\
$\mathrm{Na}_{2} \mathrm{O}$ & 1.31 & 2.85 & 1.91 & 2.97 \\
$\mathrm{~K}_{2} \mathrm{O}$ & 13.08 & 4.11 & 11.99 & 4.27 \\
$\mathrm{P}_{2} \mathrm{O}_{5}$ & 0.440 & 0.065 & 1.120 & 0.086 \\
$\mathrm{LOI} / \mathrm{H}_{2} \mathrm{O}^{+}$ & 0.33 & 0.19 & 0.44 & 0.18 \\
$\mathrm{H}_{2} \mathrm{O}^{-}$ & $<0.05$ & $<0.05$ & - & 0.10 \\
\hline Total & 98.99 & 98.07 & 97.57 & 98.97 \\
\hline $\mathrm{Ppm}$ & & & & \\
$\mathrm{Rb}$ & 215 & 368 & 686 & 241 \\
$\mathrm{Sr}$ & 327 & 9 & 318 & 30 \\
$\mathrm{Zr}$ & 186 & 1.2 & 5877 & 9 \\
\hline
\end{tabular}

${ }^{\dagger}$ Janoušek et al. (2013)

‡Vrána (1989)

$0.03-0.3 \mathrm{~mm}$, containing garnet porphyroclasts $\leq 3 \mathrm{~mm}$ and kyanite $\leq 1 \mathrm{~mm}$. An abundance of vivid blue kyanite crystals on foliation planes is a distinctive feature of this granulite type (Fig. 7a). A planar fabric is megascopically prominent, but platy quartz is recrystallized to a granular mosaic. The garnet contains 89-91 mol. \% Alm, 5.9 mol. \% Prp and 3.7-1.4 mol. \% Grs (Tab. 8). Formally, based on garnet composition, the rock would not qualify as granulite, but such a designation is supported by the unusual rock chemistry. It contains only 0.08 wt. $\% \mathrm{MgO}$, and its $\mathrm{FeOt} / \mathrm{MgO}$ ratio is 18 . An approximate pressure calculation based on garnet core (Grs = $3.7 \mathrm{~mol}$. \%) and marginally adjacent plagioclase yields $1.7 \mathrm{GPa}$ at $950^{\circ} \mathrm{C}$. Garnet rims are significantly depleted in $\mathrm{Ca}(\mathrm{Grs}=1.4 \mathrm{~mol} . \%)$, and presumably, Ca released from garnet was accommodated in the neighbouring plagioclase. Most likely, at the high-P stage plagioclase was lower in Ca content, and combination with a garnet core composition would yield a pressure higher than $1.7 \mathrm{GPa}$. Abundant mesoperthite with an Ab/Or ratio near unity and $9 \mathrm{~mol}$. \% An (reconstructed by microprobe scanning analysis; area $50 \mu \mathrm{m}$ across), indicates $\mathrm{T} \sim$ $900^{\circ} \mathrm{C}$ (calculation based on Benisek et al. 2010).

\subsection{Retrogression-related partial de- -alkalization of felsic granulites in sillimanite stability field, Pls-3, Brl-1, Hol-1}

Examples include felsic granulite Pls-3 from the Plešovice quarry (Fig. 8a), sheared Ky-Sil-Bt-Grt
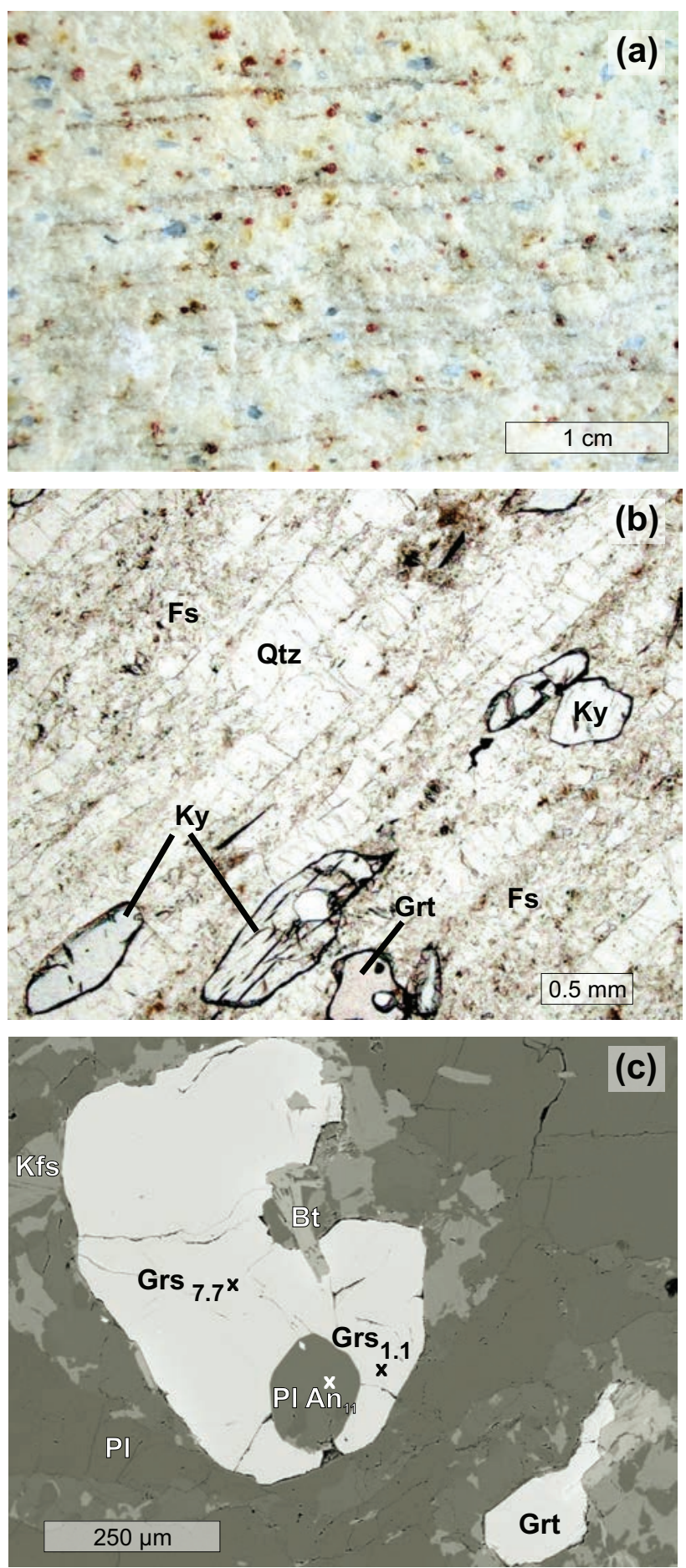

Fig. 7 Residual (type 2) granulite. a - Macrophotograph of a Ky-rich rezidual granulite from the type locality at Kokotín. $\mathbf{b}-$ Kyanite free of plagioclase rims and garnet in felsic granulite with quartz ribbons in strongly flattened fabric. Sample Pls-1, Plešovice quarry, PPL. c - Grt I with plagioclase inclusion used for GASP pressure estimate. Mol. \% Grs near center $\left(\mathrm{Grs}_{7.7}\right)$ and at rim $\left(\mathrm{Grs}_{1.1}\right)$ are indicated. Mol. \% An in $\mathrm{Pl}$ is also shown $\left(\mathrm{An}_{11}\right)$. Sample Pls-1, BSE.

granulite Brl-1 from a hillock near the Brloh village and retrogressed felsic granulite Hol-1 from the abandoned 
Contrasting mafic to felsic HP-HT granulites

Tab. 7 Electron-microprobe analyses of minerals in sample Pls-1

\begin{tabular}{|c|c|c|c|c|c|}
\hline \multirow{2}{*}{$\begin{array}{l}\text { Mineral } \\
\text { Analysis }\end{array}$} & \multicolumn{2}{|c|}{ Grt } & \multirow{2}{*}{$\begin{array}{c}\mathrm{Pl} \\
111\end{array}$} & \multirow{2}{*}{$\begin{array}{c}\mathrm{Bt} \\
114\end{array}$} & \multirow{2}{*}{$\begin{array}{l}\text { Ky } \\
107\end{array}$} \\
\hline & 109 core & $110 \mathrm{rim}$ & & & \\
\hline $\mathrm{SiO}_{2}$ & 38.13 & 38.16 & 66.54 & 37.48 & 37.82 \\
\hline $\mathrm{TiO}_{2}$ & 0.02 & 0.02 & & 0.70 & 0.00 \\
\hline $\mathrm{Al}_{2} \mathrm{O}_{3}$ & 21.42 & 21.25 & 21.40 & 20.02 & 63.09 \\
\hline $\mathrm{Cr}_{2} \mathrm{O}_{3}$ & 0.00 & 0.02 & & 0.01 & 0.00 \\
\hline FeOt & 32.35 & 34.13 & 0.46 & 16.20 & 0.04 \\
\hline $\mathrm{MnO}$ & 0.84 & 0.87 & & 0.02 & 0.03 \\
\hline $\mathrm{MgO}$ & 5.12 & 5.74 & & 12.17 & 0.00 \\
\hline $\mathrm{CaO}$ & 3.32 & 1.03 & 2.31 & 0.00 & 0.00 \\
\hline $\mathrm{Na}_{2} \mathrm{O}$ & 0.00 & 0.03 & 10.52 & 0.07 & 0.00 \\
\hline $\mathrm{K}_{2} \mathrm{O}$ & & & 0.19 & 8.47 & 0.00 \\
\hline $\mathrm{P}_{2} \mathrm{O}_{5}$ & 0.09 & 0.09 & 0.00 & & - \\
\hline $\mathrm{Y}_{2} \mathrm{O}_{3}$ & 0.01 & 0.00 & & & \\
\hline $\mathrm{V}_{2} \mathrm{O}_{3}$ & 0.02 & 0.02 & & & \\
\hline $\mathrm{F}$ & & & & 1.26 & 0.04 \\
\hline Total & 101.32 & 101.33 & 101.42 & 96.40 & 101.02 \\
\hline \multicolumn{6}{|c|}{ Atoms per given number of oxygen atoms } \\
\hline $\mathrm{O}$ & 12 & 12 & 8 & 22 & 5 \\
\hline $\mathrm{Si}$ & 2.984 & 2.991 & 2.886 & 5.547 & 1.010 \\
\hline $\mathrm{Al}^{\mathrm{iv}}$ & 0.016 & 0.009 & 1.094 & 2.453 & 1.986 \\
\hline $\mathrm{Al}^{\mathrm{vi}}$ & 1.963 & 1.957 & & 1.040 & \\
\hline $\mathrm{Ti}$ & 0.001 & 0.001 & & 0.078 & \\
\hline $\mathrm{Cr}$ & 0.000 & 0.001 & & 0.001 & \\
\hline $\mathrm{Fe}^{3+}$ & 0.032 & 0.036 & 0.017 & & 0.001 \\
\hline $\mathrm{Fe}^{2+}$ & 2.086 & 2.201 & 0.000 & 2.005 & \\
\hline Mn & 0.056 & 0.058 & & 0.003 & 0.001 \\
\hline $\mathrm{Mg}$ & 0.597 & 0.671 & & 2.685 & \\
\hline $\mathrm{Ca}$ & 0.278 & 0.086 & 0.107 & 0.000 & \\
\hline $\mathrm{Na}$ & & & 0.885 & 0.020 & \\
\hline K & & & 0.011 & 1.599 & \\
\hline $\mathrm{F}$ & & & & 0.590 & \\
\hline $\mathrm{OH}^{*}$ & & & & 3.410 & \\
\hline Total & 8.013 & 8.011 & 5.000 & 19.430 & 2.998 \\
\hline \multicolumn{6}{|c|}{ End-members (mol. \%) } \\
\hline Almandine & 68.79 & 72.75 & An 11.0 & & \\
\hline Andradite & 1.60 & 1.82 & Ab 88.0 & & \\
\hline Grossular & 7.73 & 1.01 & Or 1.0 & & \\
\hline Pyrope & 20.02 & 22.42 & & & \\
\hline Spessartine & 1.87 & 1.93 & & & \\
\hline Uvarovite & 0.00 & 0.06 & & & \\
\hline
\end{tabular}

Holašovice quarry (Fig. 8b). Fine-grained granulite Pls-3 (0.05-0.5 mm) has the following composition (based on visual estimate, vol. \%): 40 Qtz, 25 Kfs, 25 Pl, 4 Bt, 2 Grt, 2 Sil and $1 \mathrm{Ky}$. Owing to finely dispersed biotite the rock resembles a metasedimentary rock.

The mylonitic matrix of sample Brl-1 contains Grt and Kfs porphyroclasts up to $3 \mathrm{~mm}$. The rock has an estimated modal composition of $40 \mathrm{Qtz}, 28 \mathrm{Pl}, 25 \mathrm{Kfs}, 2$ Grt, 2 Sil, $1 \mathrm{Ky}$, and $1 \mathrm{Bt}$.

Retrogressed granulite Hol-1 is fine-grained (0.1-1 $\mathrm{mm}$ ) and nearly free of garnet. The rock has the following composition: 40 Qtz, 29 Kfs, 27 Pl, 3 Bt, 2 Sil, and less than $0.2 \mathrm{Grt}$.
Tab. 8 Electron-microprobe analyses of minerals in sample Klt-20

\begin{tabular}{|c|c|c|c|c|c|c|}
\hline \multirow{2}{*}{$\begin{array}{l}\text { Mineral } \\
\text { Analysis }\end{array}$} & \multicolumn{2}{|c|}{ Grt } & \multirow{2}{*}{$\begin{array}{l}\mathrm{Pl} \\
35\end{array}$} & \multirow{2}{*}{$\begin{array}{c}\text { MP } \\
40\end{array}$} & \multirow{2}{*}{$\begin{array}{l}\text { Ky } \\
32\end{array}$} & \multirow{2}{*}{$\begin{array}{l}\mathrm{Rt} \\
75\end{array}$} \\
\hline & 33 core & $34 \mathrm{rim}$ & & & & \\
\hline $\mathrm{SiO}_{2}$ & 36.09 & 36.28 & 66.47 & 60.85 & 37.31 & 0.05 \\
\hline $\mathrm{TiO}_{2}$ & 0.03 & 0.02 & & & 0.00 & 99.74 \\
\hline $\mathrm{Al}_{2} \mathrm{O}_{3}$ & 20.97 & 20.85 & 21.29 & 18.46 & 63.22 & 0.03 \\
\hline $\mathrm{Cr}_{2} \mathrm{O}_{3}$ & 0.02 & 0.02 & & & 0.01 & 0.01 \\
\hline FeOt & 38.76 & 39.43 & 0.23 & 0.01 & 0.25 & 0.28 \\
\hline $\mathrm{MnO}$ & 0.75 & 0.80 & & & 0.03 & 0.00 \\
\hline $\mathrm{MgO}$ & 1.35 & 1.44 & & & 0.00 & 0.00 \\
\hline $\mathrm{CaO}$ & 1.26 & 0.49 & 1.93 & 0.45 & 0.02 & 0.00 \\
\hline $\mathrm{Na}_{2} \mathrm{O}$ & 0.05 & 0.02 & 10.78 & 6.20 & 0.00 & 0.00 \\
\hline $\mathrm{K}_{2} \mathrm{O}$ & 0.00 & 0.00 & 0.12 & 7.18 & 0.02 & \\
\hline $\mathrm{Y}_{2} \mathrm{O}_{3}$ & 0.01 & 0.01 & & & & \\
\hline $\mathrm{V}_{2} \mathrm{O}_{3}$ & 0.01 & 0.00 & & & 0.00 & 0.02 \\
\hline $\mathrm{P}_{2} \mathrm{O}_{5}$ & 0.33 & 0.13 & 0.09 & 0.09 & 0.05 & \\
\hline $\mathrm{ZrO}$ & & & & & & 0.26 \\
\hline $\mathrm{ZnO}$ & & & & & 0.00 & 0.09 \\
\hline $\mathrm{Nb}_{2} \mathrm{O}_{5}$ & & & & & & 0.01 \\
\hline Total & 99.63 & 99.49 & 100.91 & 93.24 & 100.91 & 100.49 \\
\hline \multicolumn{7}{|c|}{ Atoms per given number of oxygen atoms } \\
\hline $\mathrm{O}$ & 12 & 12 & 5 & 5 & 5 & 2 \\
\hline Si & 2.969 & 2.983 & 2.893 & 2.918 & 0.984 & 0.001 \\
\hline $\mathrm{Al}^{\mathrm{iv}}$ & 0.031 & 0.017 & 1.092 & 1.043 & 1.965 & \\
\hline $\mathrm{Al}^{\mathrm{vi}}$ & 2.004 & 2.006 & & & & 0.000 \\
\hline $\mathrm{Ti}$ & 0.002 & 0.001 & & & & 0.996 \\
\hline $\mathrm{Cr}$ & 0.001 & 0.001 & & & 0.000 & \\
\hline $\mathrm{Fe}^{3+}$ & 0.000 & 0.000 & 0.008 & 0.000 & 0.005 & 0.003 \\
\hline $\mathrm{Fe}^{2+}$ & 2.677 & 2.723 & 0.000 & 0.000 & & 0.000 \\
\hline Mn & 0.052 & 0.056 & & & 0.001 & \\
\hline $\mathrm{Mg}$ & 0.166 & 0.177 & & & & \\
\hline $\mathrm{Ca}$ & 0.111 & 0.043 & 0.090 & 0.023 & 0.001 & \\
\hline $\mathrm{Na}$ & & & 0.910 & 0.576 & & \\
\hline K & & & 0.007 & 0.439 & & \\
\hline Total & 8.013 & 8.007 & 5.000 & 4.999 & 2.956 & 1.000 \\
\hline \multicolumn{7}{|c|}{ End-members (mol. \%) } \\
\hline Almandine & 88.92 & 90.77 & An 9.0 & An 2.0 & & \\
\hline Andradite & 0.00 & 0.00 & Ab 90.0 & Ab 55.0 & & \\
\hline Grossular & 3.68 & 1.38 & Or 1.0 & Or 42.0 & & \\
\hline Pyrope & 5.58 & 5.92 & & & & \\
\hline Spessartine & 1.76 & 1.87 & & & & \\
\hline Uvarovite & 0.07 & 0.07 & & & & \\
\hline
\end{tabular}

MP - mesoperthite

Common to all three samples are 1-2 mm thick bands of sillimanite II and quartz, localized along late generation $\mathrm{S}_{3}$ shear-foliation or semibrittle fractures. Prismatic to acicular sillimanite II differs texturally from fibrolitic sillimanite I, which formed by inversion of kyanite elsewhere in the BLGM. Feldspars are absent in these bands and no relation to possible former kyanite sites is indicated. These bands are interpreted as a product of partial de-alkalization of feldspars comparable to numerous examples of sillimanite-quartz nodules or bands from a variety of amphibolite-facies complexes in the Moldanubian Zone of the Bohemian 

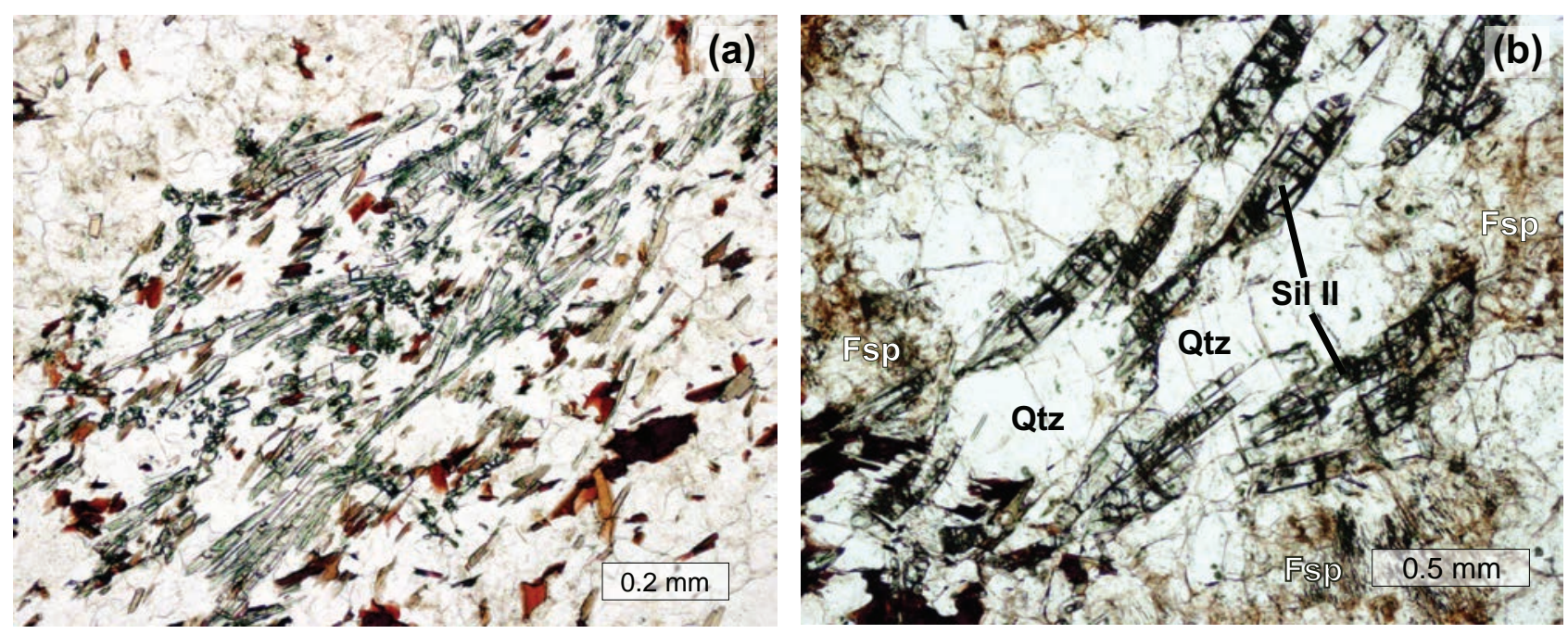

Fig. 8 Retrogression-related partial de-alkalization of felsic granulites in sillimanite stability field. a - Local Sill II-Qtz lens + Bt marking de-alkalization domain in partly retrogressed felsic biotite-kyanite-garnet granulite. Sample Pls-3, Plešovice quarry, PPL. b - Sillimanite II-quartz band in retrogressed granulite resulting from local de-alkalization of feldspars. Sample Hol-1, disused Holašovice quarry, PPL.

Massif and other localities worldwide (e.g. Losert 1968, 1977). Volumes affected by the partial de-alkalization in the three samples are estimated to be $c$. $5 \%$, but the phenomenon is difficult to recognise without a microscope.

\subsection{Local variations in oxygen fugacity, samples H232 and H232E}

Sample H232 has the following modal composition (wt. \%): 19.9 Qtz, 51.3 Pl, 4.0 Kfs, 10.0 Grt, 6.0 Opx, $2.5 \mathrm{Cpx}, 3 \mathrm{Bt}, 2.5 \mathrm{Ilm}$ and $0.25 \mathrm{Ap}$. These proportions are based on a Catanorm calculation and thin section estimates of minor and accessory components.

The rock forms a c. $60 \mathrm{~m}$ boudin in felsic granulite of weakly foliated intermediate granulite of tonalitic composition (Fig. 9a-b), with minor magnetite in plagioclase + orthopyroxene \pm biotite symplectite aggregates around Grt. A younger symplectite II formed along some fractures in Grt (Fig. 9a, Tab. 9). Structurally the locality exhibits an overprint of $\mathrm{S}_{2}$ by $\mathrm{S}_{3}$ fabric.

Sláma et al. (2007) dated the decompression reaction, $\mathrm{Grt} \rightarrow \mathrm{Opx}+\mathrm{Pl}+\mathrm{Hbl}\left(1.2-1.4 \mathrm{GPa}, 1000^{\circ} \mathrm{C}\right)$, in this intermediate granulite boudin at 333 and $331 \mathrm{Ma}(\mathrm{Lu}-\mathrm{Hf}$ mineral data). Another similar sample from this locality was described by Faryad et al. (2010), who reported a single relict grain of omphacite $\left(\mathrm{Jd}_{28}\right)$ in garnet. In our sample, Ca-in-Opx thermometry (Brey and Köhler 1990) gave $767-833^{\circ} \mathrm{C}$ at $0.7 \mathrm{GPa}$, and orthopyroxene-biotite thermometry yielded $500^{\circ} \mathrm{C}$ (at $0.7 \mathrm{GPa}$ ).

Felsic garnet granulite from the vicinity of the mafic boudin, sample $\mathrm{H} 232 \mathrm{E}$, contains minor magnetite $\leq 200$ $\mu \mathrm{m}$, altered to hematite, around corroded garnet and in spinel-plagioclase pseudomorphs after kyanite (Fig. 9c,
Tab. 10). Otherwise it consists of a common felsic granulite mineral assemblage.

\subsection{Garnet-rich metabasite carrying ilmenite- hornblende symplectites, PlsGrt 2}

This minor rock type forms $\mathrm{cm}$ - to dm-sized, cigarshaped boudins in felsic granulites in the Plešovice quarry. Structures in this part of the quarry display a heterogeneous transition from $\mathrm{S}_{2}$ to dominant $\mathrm{S}_{3}$ fabrics. A visual estimate of the modal composition is (vol. \%): 38 Pl, 25 Grt, 10 Ilm, 8 Amp, 7 Qtz, 5 Bt, 3 Ap, 3 Po, $<1 \mathrm{Rt}$. The average grain size is $0.2-1 \mathrm{~mm}$.

The texture is dominated by $\mathrm{Pl}+\mathrm{Hbl}$ symplectite around Grt relicts and $\mathrm{Ilm}+\mathrm{Hbl}+\mathrm{Pl}$ symplectite (Fig. 10a, Tab. 11). In places, where surrounded by Qtz, the Grt is preserved. The total volume of ilmenite symplectite is estimated to be $10-15$ vol. \%; rutile is found solely as rare and minute inclusions in garnet. The ilmenite symplectite most likely resulted from reaction of titanite with the enclosing minerals.

As no titanite was observed in this sample, a similar mafic enclave, $20 \mathrm{~cm}$ across, from the Zrcadlová Hut' quarry (sample LV110) was used for supplementary information. A visual estimate of the modal composition is (vol. \%): $50 \mathrm{Pl}, 10 \mathrm{Opx}, 10 \mathrm{Qtz}, 5 \mathrm{Ilm}, 5 \mathrm{Bt}, 4 \mathrm{Cpx}, 3$ Grt, 2 Po, accessory Tnt, Ap and Rt. The average grain size is $0.2-1 \mathrm{~mm}$. The fabric is dominated by radiating Cpx + Pl symplectites after Grt and peripheral coarser Opx (Fig. 10b).

The stage of titanite formation in mafic rocks is difficult to constrain, as the presumed evolution of the mafic protolith from eclogite to mafic granulite did not include conditions suitable for titanite formation. One possible 

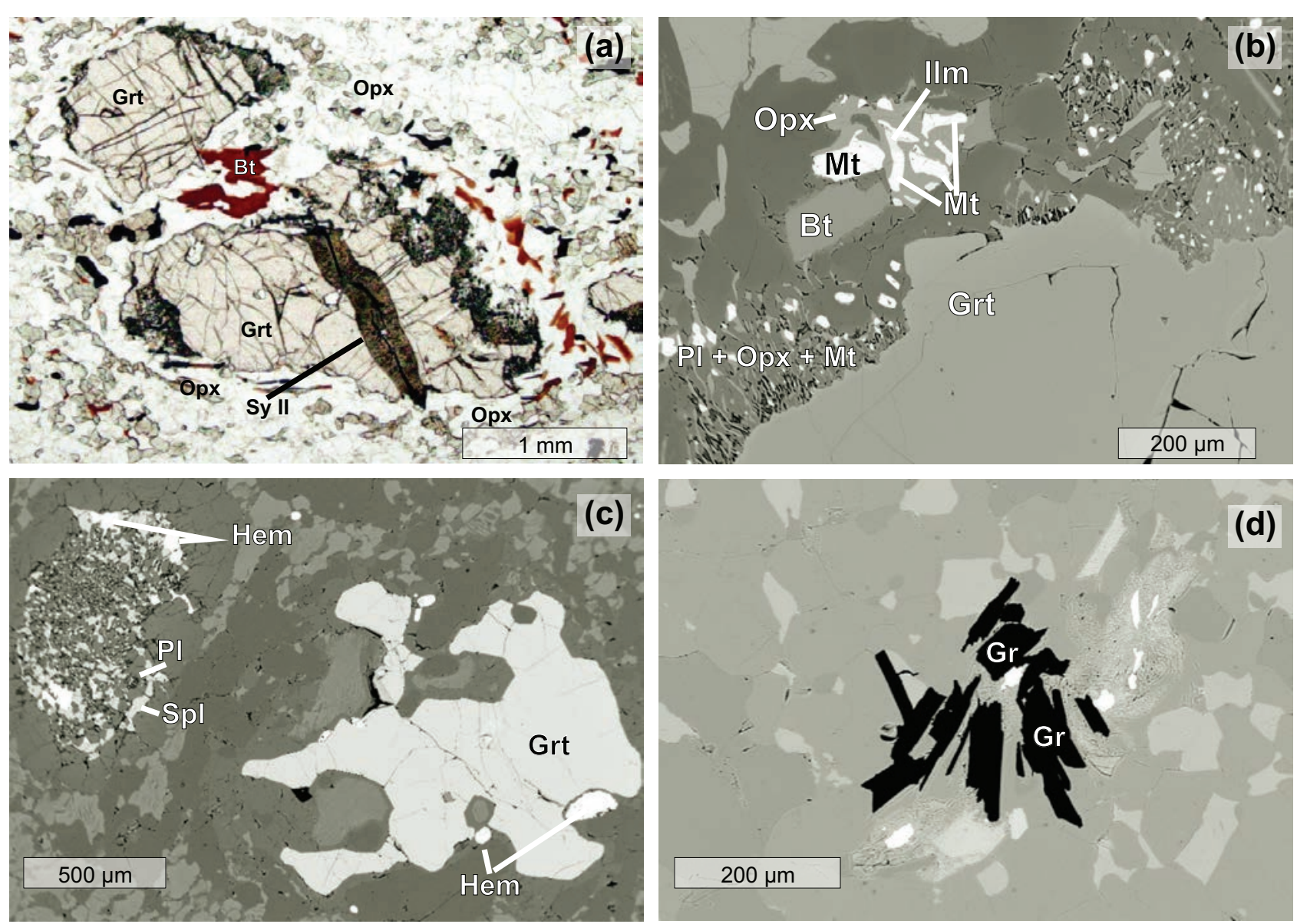

Fig. 9 Local variations in oxygen fugacity. a - Partly consumed garnet in intermediate granulite is surrounded by an inner rim of plagioclase (white) and outer rim of granular orthopyroxene. A younger symplectite (SyII) of clinozoisite \pm amphibole and plagioclase transects garnet. Sample H232, PPL. b - Magnetite-orthopyroxene-plagioclase symplectite around garnet. Sample H232, BSE. c - Hematite after magnetite in felsic garnet granulite with spinel-plagioclase pseudomorphs after former kyanite. Sample H232E, near domain of the above described intermediate granulite with magnetite (H232). d - A cluster of graphite crystals (Gr), associated with biotite, and surrounded by feldspar-quartz mosaic. Sample 1059, Holubov borehole, BSE. For whole-rock chemical composition, see Janoušek et al. (2004).
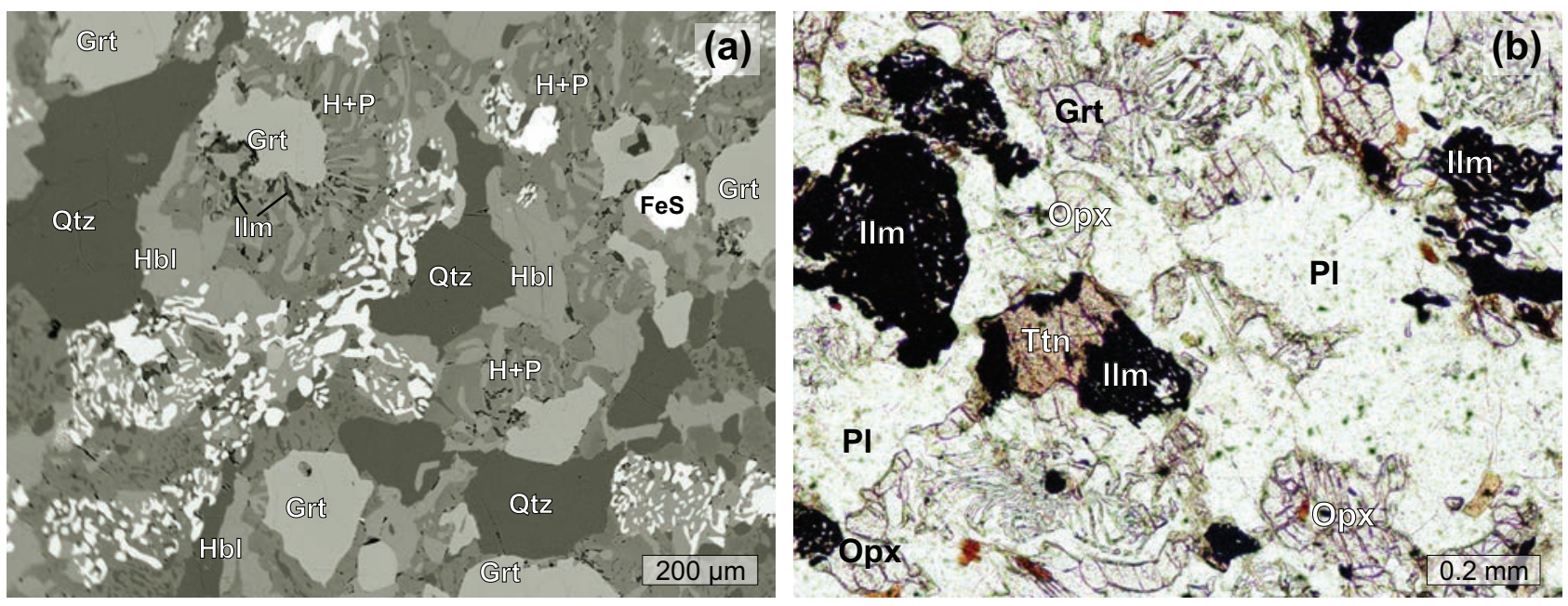

Fig. 10 Garnet-rich metabasite with Ilm-Hbl symplectites. a - Ilmenite + Hbl + Pl symplectite associated with garnet reacted extensively to Hbl + Pl symplectite $(\mathrm{H}+\mathrm{P})$, quartz and plagioclase. Sample PlsGrt 2, Plešovice quarry, BSE. b - Titanite relic associated with ilmenite-plagioclase symplectites in two-pyroxene granulite with relict garnet. Sample LV110, PPL. 
Tab. 9 Electron-microprobe analyses of minerals in sample H-232

\begin{tabular}{|c|c|c|c|c|c|c|c|c|c|c|c|}
\hline Mineral & Grt core & Grt rim & $\mathrm{Pl}$ & $\mathrm{Pl}$ & Opx & Opx & $\mathrm{Bt}$ & Cli & $\mathrm{Ilm}$ & $\mathrm{Mt}$ & $\mathrm{Bd}$ \\
\hline Analysis & 7 & 6 & 16 & 3 & $8^{*}$ & $14^{*}$ & 10 & 2 & 12 & 15 & 13 \\
\hline $\mathrm{SiO}_{2}$ & 38.96 & 38.65 & 47.75 & 54.90 & 51.67 & 52.14 & 37.17 & 38.41 & 0.00 & 0.17 & 0.00 \\
\hline $\mathrm{TiO}_{2}$ & 0.27 & 0.19 & & & 0.16 & 0.75 & 6.65 & 0.00 & 50.34 & 0.07 & 0.45 \\
\hline $\mathrm{Al}_{2} \mathrm{O}_{3}$ & 21.44 & 21.33 & 33.47 & 27.93 & 1.15 & 1.24 & 13.89 & 29.81 & 0.02 & 0.38 & 0.00 \\
\hline $\mathrm{Cr}_{2} \mathrm{O}_{3}$ & 0.01 & 0.02 & & & 0.05 & 0.02 & 0.18 & 0.01 & 0.08 & 0.19 & \\
\hline FeOt & 19.46 & 21.05 & 0.65 & 1.29 & 28.75 & 27.50 & 17.46 & 6.05 & 48.28 & 93.05 & 0.56 \\
\hline $\mathrm{MnO}$ & 0.40 & 0.46 & & & 0.46 & 0.60 & 0.08 & 0.08 & 0.48 & 0.02 & \\
\hline $\mathrm{MgO}$ & 5.55 & 5.32 & & & 17.56 & 19.04 & 11.57 & 0.70 & 0.07 & 0.04 & \\
\hline $\mathrm{CaO}$ & 14.13 & 13.22 & 17.36 & 10.95 & 0.73 & 0.54 & 0.02 & 22.90 & 0.01 & 0.04 & 0.02 \\
\hline $\mathrm{Na}_{2} \mathrm{O}$ & 0.03 & 0.03 & 1.99 & 4.96 & 0.04 & 0.02 & 0.03 & 0.03 & & & \\
\hline $\mathrm{K}_{2} \mathrm{O}$ & 0.00 & 0.01 & 0.08 & 0.20 & 0.00 & 0.01 & 9.76 & 0.01 & 0.03 & & \\
\hline $\mathrm{BaO}$ & & & 0.00 & 0.02 & 0.03 & 0.00 & 0.26 & 0.00 & & & \\
\hline $\mathrm{SrO}$ & & & 0.00 & 0.00 & & & & & 0.00 & & \\
\hline $\mathrm{V}_{2} \mathrm{O}_{3}$ & 0.03 & 0.02 & & & 0.08 & 0.00 & 0.27 & 0.00 & 0.29 & 0.27 & \\
\hline $\mathrm{P}_{2} \mathrm{O}_{5}$ & 0.04 & 0.02 & 0.06 & 0.00 & & & & & & & 0.03 \\
\hline $\mathrm{ZnO}$ & & & & & 0.02 & 0.09 & 0.07 & 0.00 & 0.04 & 0.06 & \\
\hline $\mathrm{NiO}$ & & & & & 0.03 & 0.02 & 0.06 & 0.01 & & 0.00 & \\
\hline $\mathrm{Nb}_{2} \mathrm{O}_{5}$ & & & & & & & & 0.11 & 0.11 & & \\
\hline $\mathrm{ZrO}_{2}$ & & & & & & & & & & & 99.24 \\
\hline $\mathrm{HfO}_{2}$ & & & & & & & & & & & 0.97 \\
\hline $\mathrm{F}$ & 0.03 & 0.02 & & & 0.00 & 0.00 & 0.54 & 0.11 & & & \\
\hline Total & 100.35 & 100.34 & 101.36 & 100.25 & 100.72 & 101.97 & 98.01 & 98.21 & 99.73 & 94.27 & 101.27 \\
\hline \multicolumn{12}{|c|}{ Atoms per given number of oxygen atoms } \\
\hline $\mathrm{O}$ & 12 & 12 & 8 & 8 & 6 & 6 & 22 & 12.5 & 3 & 4 & 1 \\
\hline Si & 2.985 & 2.977 & 2.164 & 2.484 & 1.973 & 1.954 & 5.546 & 2.941 & 0.000 & 0.006 & \\
\hline $\mathrm{Al}^{\mathrm{iv}}$ & 0.015 & 0.023 & 1.788 & 1.490 & 0.052 & 0.055 & 2.443 & 2.690 & 0.001 & 0.017 & \\
\hline $\mathrm{Al}^{\mathrm{vi}}$ & 1.926 & 1.918 & & & & & 0.000 & & & & \\
\hline $\mathrm{Ti}$ & 0.016 & 0.011 & & & 0.005 & 0.021 & 0.746 & & 0.960 & 0.002 & 0.007 \\
\hline $\mathrm{Cr}$ & 0.001 & 0.001 & & & 0.002 & 0.001 & 0.021 & 0.001 & 0.002 & 0.006 & \\
\hline $\mathrm{Fe}^{3+}$ & 0.051 & 0.062 & 0.025 & 0.000 & 0.000 & 0.000 & & 0.387 & 0.079 & 1.962 & 0.009 \\
\hline $\mathrm{Fe}^{2+}$ & 1.196 & 1.294 & 0.000 & 0.049 & 0.918 & 0.862 & 2.179 & & 0.945 & 0.993 & \\
\hline $\mathrm{Mn}$ & 0.026 & 0.030 & & & 0.015 & 0.019 & 0.010 & 0.005 & 0.010 & 0.001 & \\
\hline $\mathrm{Mg}$ & 0.634 & 0.611 & & & 0.999 & 1.063 & 2.573 & 0.080 & 0.003 & 0.002 & \\
\hline $\mathrm{Ni}$ & 0.000 & 0.000 & & & 0.001 & 0.001 & 0.000 & & & 0.008 & \\
\hline $\mathrm{Ca}$ & 1.160 & 1.091 & 0.843 & 0.531 & 0.030 & 0.022 & 0.003 & 1.878 & & 0.002 & \\
\hline $\mathrm{Na}$ & & & 0.175 & 0.435 & 0.003 & 0.001 & 0.009 & 0.005 & & 0.000 & \\
\hline $\mathrm{K}$ & & & 0.005 & 0.012 & 0.000 & 0.000 & 1.858 & 0.001 & 0.001 & 0.001 & \\
\hline $\mathrm{Zr}$ & & & & & & & & & & & 0.976 \\
\hline $\mathrm{F}$ & & & & & & & 0.255 & & & & \\
\hline $\mathrm{OH}^{*}$ & & & & & & & 3.745 & & & & \\
\hline Total & 8.010 & 8.018 & 5.000 & 5.001 & 3.998 & 3.999 & 19.388 & 7.992 & 2.001 & 3.000 & 0.992 \\
\hline \multicolumn{12}{|c|}{ End-members (mol. \%) } \\
\hline Almandine & 38.98 & 41.82 & An 82.4 & An 54.3 & & & & & & & \\
\hline Andradite & 2.59 & 3.12 & Ab 17.1 & Ab 44.5 & & & & & & & \\
\hline Grossular & 36.28 & 33.47 & Or 0.5 & Or 1.2 & & & & & & & \\
\hline Pyrope & 21.25 & 20.52 & & & & & & & & & \\
\hline Spessartine & 0.87 & 1.01 & & & & & & & & & \\
\hline Uvarovite & 0.03 & 0.06 & & & & & & & & & \\
\hline
\end{tabular}

Opx $8 *$ is from mosaic with $\mathrm{Bt}$ and $\mathrm{Pl}$, Opx $14 *$ is from coarse symplectite with ilmenite around Grt

Bd 13 contains also 0.16 wt. \% Th, U and HREE oxides.

explanation for titanite occurrence would be low-grade alteration of the mafic protolith prior to eclogitization, or alternatively the presence of igneous titanite relics from the protolith.

\section{Discussion}

This contribution presents evidence for processes and mineral assemblages previously unrecognized in the 
BLGM, but which are important to unravel the complex granulite history, $\mathrm{P}-\mathrm{T}$ conditions, and changes in rock compositions.

\subsection{Heterogeneous preservation of early mineral assemblages in orthopyroxene- biotite-garnet granulites of granodiorite composition}

Granulite of granodiorite composition (Klt-1) preserves an early mineral assemblage of Cpx + Grt I, as well as domains of minerals indicating the reactions, Grt I $\rightarrow$ $\mathrm{Opx}+\mathrm{Pl}$, and $\mathrm{Ky}+\mathrm{Grt} \mathrm{I}+\mathrm{Bt}+$ $\mathrm{Pl} \mathrm{I} \rightarrow$ Grt II $+\mathrm{Spl}+\mathrm{Pl}$ II, in a single thin section. This observation is interpreted such that the two reactions and accompanying recrystallizations were confined to specific reaction sites involving short-range transfer of ions, whereas elsewhere, the original assemblage was preserved on a mm-scale.

Similar phenomena were addressed several times in the literature, with the conclusion that such reactions are diffusioncontrolled (Loomis 1979; Harley 1989; Messiga and Bettini 1990; Owen and Dostal 1996; Ashworth et al. 1998). The silica-undersaturated character of former kyanite sites with their plagioclase rims (Tajčmanová et al. 2007, 2011; Štípská et al. 2010) follows from the composition of kyanite, whose atomic ratio of $\mathrm{Al}: \mathrm{Si}$ is $2: 1$, whereas the other minerals involved have much lower ratios: garnet $2: 3$, alkali feldspars $1: 3$. Attempts to define a "spheroidal compositional volume" around such pseudomorphs (Tajčmanová et al. 2007) by thermodynamic modelling and the construction of pseudosections are invalid, because the starting composition of the kyanite-bearing micro-domain was vastly different from the final one, resulting from the low diffusivity of $\mathrm{Al}$ and $\mathrm{Si}$ and high diffusivity of $\mathrm{Fe}, \mathrm{Mg}, \mathrm{Ca}$ and
Tab. 10 Electron-microprobe analyses of minerals in sample H-232E

\begin{tabular}{|c|c|c|c|c|c|c|c|}
\hline Mineral & Grt & Grt & $\mathrm{Pl}$ & $\mathrm{Pl}$ & MP & Hem & Spl \\
\hline Analysis & 74 & 71 & 68 & 72 & 76 & 75 & 67 \\
\hline $\mathrm{SiO}_{2}$ & 37.91 & 37.78 & 60.45 & 65.23 & 64.51 & 0.08 & 0.04 \\
\hline $\mathrm{TiO}_{2}$ & 0.06 & 0.02 & & & & 0.00 & 0.01 \\
\hline $\mathrm{Al}_{2} \mathrm{O}_{3}$ & 20.97 & 20.86 & 25.11 & 22.21 & 18.94 & 0.29 & 56.25 \\
\hline $\mathrm{Cr}_{2} \mathrm{O}_{3}$ & 0.00 & 0.00 & & & & 0.02 & 0.01 \\
\hline $\mathrm{FeOt}$ & 30.33 & 33.81 & 0.51 & 0.18 & 0.07 & 89.34 & 39.00 \\
\hline $\mathrm{MnO}$ & 0.52 & 0.63 & & & & 0.00 & 0.22 \\
\hline $\mathrm{MgO}$ & 3.55 & 4.38 & & & & 0.00 & 4.54 \\
\hline $\mathrm{CaO}$ & 6.59 & 2.05 & 6.61 & 3.17 & 0.75 & 0.01 & 0.03 \\
\hline $\mathrm{Na}_{2} \mathrm{O}$ & 0.02 & 0.01 & 8.14 & 9.93 & 4.85 & 0.00 & \\
\hline $\mathrm{K}_{2} \mathrm{O}$ & 0.00 & 0.00 & 0.17 & 0.17 & 9.54 & & \\
\hline $\mathrm{Y}_{2} \mathrm{O}_{3}$ & 0.18 & 0.18 & & & & & \\
\hline $\mathrm{V}_{2} \mathrm{O}_{3}$ & 0.01 & 0.01 & & & & 0.02 & 0.00 \\
\hline $\mathrm{P}_{2} \mathrm{O}_{5}$ & 0.06 & 0.02 & 0.04 & 0.01 & 0.00 & & \\
\hline $\mathrm{ZnO}$ & & & & & & & 0.19 \\
\hline $\mathrm{NiO}$ & & & & & & 0.00 & 0.04 \\
\hline Total & 100.20 & 99.75 & 101.03 & 100.90 & 98.66 & 89.76 & 100.33 \\
\hline
\end{tabular}

Atoms per given number of oxygen atoms

\begin{tabular}{llllllll} 
& 12 & 12 & 8 & 8 & 8 & 3 & 4 \\
\hline Si & 3.007 & 3.025 & 2.662 & 2.850 & 2.952 & 0.002 & 0.001
\end{tabular}

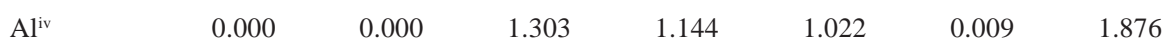

$\mathrm{Al}^{\mathrm{vi}} \quad 1.962 \quad 1.969 \quad 0.004-0.001$

$\begin{array}{lllll}\text { Ti } & 0.004 & 0.001 & 0.000 & 0.000\end{array}$

$\begin{array}{llllll}\mathrm{Cr} & 0.000 & 0.000 & 0.000 & 0.000\end{array}$

$\begin{array}{llllllll}\mathrm{Fe}^{3+} & 0.024 & 0.004 & 0.019 & 0.006 & 0.003 & 1.986 & 0.122\end{array}$

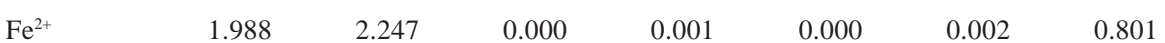

$\begin{array}{llll}\text { Mn } & 0.035 & 0.043 & 0.005\end{array}$

$\begin{array}{llll}\mathrm{Mg} & 0.420 & 0.523 & 0.191\end{array}$

$\begin{array}{llll}\mathrm{Ni} & 0.000 & 0.000 & 0.001\end{array}$

$\begin{array}{llllll}\mathrm{Zn} & 0.000 & 0.000 & & & \\ \mathrm{C} & 0.560 & 0.176 & 0.312 & 0.148 & 0.037\end{array}$

$\mathrm{Na} \quad 0.695 \quad 0.841 \quad 0.430$

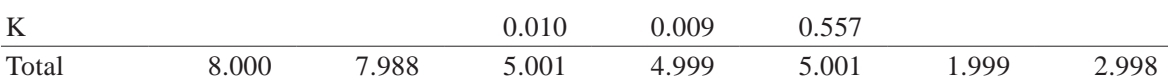

End-members (mol. \%)

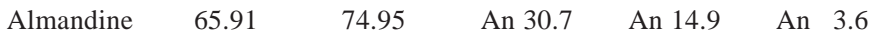

Andradite $\quad 1.22 \quad 0.21 \quad$ Ab 68.4 Ab 84.2 $\quad$ Ab 42.0

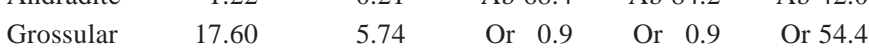

Pyrope $\quad 14.10 \quad 17.67$

Spessartine $\quad 1.17 \quad 1.44$

$\begin{array}{lll}\text { Uvarovite } & 0.00 & 0.00\end{array}$

MP - mesoperthite 
Tab. 11 Electron-microprobe analyses of minerals in sample Pls1Grt2

\begin{tabular}{|c|c|c|c|c|c|c|c|}
\hline Mineral & Grt I & Grt II & Pl & $\mathrm{Pl}$ & $\mathrm{Bt}$ & Ky & Ilm \\
\hline Analysis & 21 & 12 & 20 & 22 & 16 & 11 & 18 \\
\hline $\mathrm{SiO}_{2}$ & 38.18 & 38.21 & 62.62 & 58.91 & 37.34 & 37.15 & 0.01 \\
\hline $\mathrm{TiO}_{2}$ & 0.10 & 0.03 & & & 4.20 & 0.04 & 52.73 \\
\hline $\mathrm{Al}_{2} \mathrm{O}_{3}$ & 21.34 & 20.89 & 22.85 & 25.48 & 16.68 & 62.67 & 0 \\
\hline $\mathrm{Cr}_{2} \mathrm{O}_{3}$ & 0 & 0.03 & & & 0.07 & 0.02 & 0.02 \\
\hline FeOt & 25.97 & 30.97 & 0.02 & 0.15 & 12.12 & 0.21 & 44.94 \\
\hline $\mathrm{MnO}$ & 0.44 & 0.5 & & & 0.05 & 0.01 & 0.12 \\
\hline MgO & 5.40 & 6.71 & & & 15.30 & 0.04 & 0.83 \\
\hline $\mathrm{CaO}$ & 8.34 & 2.46 & 4.64 & 7.5 & 0.04 & 0 & 0 \\
\hline $\mathrm{Na}_{2} \mathrm{O}$ & 0.03 & 0.02 & 8.62 & 7.39 & 0.07 & 0 & \\
\hline $\mathrm{K}_{2} \mathrm{O}$ & 0.01 & 0 & 0.27 & 0.33 & 9.59 & 0 & 0 \\
\hline $\mathrm{BaO}$ & & & & & 0.15 & & \\
\hline $\mathrm{P}_{2} \mathrm{O}_{5}$ & 0.06 & 0.02 & 0.03 & 0.06 & & & \\
\hline $\mathrm{Y}_{2} \mathrm{O}_{3}$ & 0.03 & 0 & & & & & \\
\hline $\mathrm{V}_{2} \mathrm{O}_{3}$ & 0.01 & 0.05 & & & 0.19 & 0.01 & 0.14 \\
\hline $\mathrm{Nb}_{2} \mathrm{O}_{5}$ & & & & & & & 0.10 \\
\hline $\mathrm{F}$ & 0.05 & 0.06 & & & 2.70 & 0.03 & \\
\hline Total & 99.96 & 99.95 & 99.05 & 99.82 & 98.50 & 100.18 & 98.89 \\
\hline
\end{tabular}

Atoms per given number of oxygen atoms

\begin{tabular}{|c|c|c|c|c|c|c|c|}
\hline $\mathrm{O}$ & 12 & 12 & 8 & 8 & 22 & 5 & 3 \\
\hline Si & 2.983 & 3.003 & 2.806 & 2.633 & 5.491 & 1.000 & 0.000 \\
\hline $\mathrm{Al}^{\mathrm{iv}}$ & 0.017 & 0.000 & 1.207 & 1.343 & 2.509 & 1.988 & 0.000 \\
\hline $\mathrm{Al}^{\mathrm{vi}}$ & 1.952 & 1.939 & & & 0.382 & & \\
\hline $\mathrm{Ti}$ & 0.006 & 0.002 & & & 0.445 & 0.001 & 1.008 \\
\hline $\mathrm{Cr}$ & 0.001 & 0.001 & & & 0.008 & & 0.002 \\
\hline $\mathrm{Fe}^{3+}$ & 0.037 & 0.049 & 0.000 & 0.006 & & 0.005 & 0.000 \\
\hline $\mathrm{Fe}^{2+}$ & 1.660 & 1.987 & 0.001 & 0.000 & 1.491 & & 0.955 \\
\hline Mn & 0.029 & 0.033 & & & 0.006 & & 0.003 \\
\hline $\mathrm{Mg}$ & 0.629 & 0.786 & & & 3.354 & 0.002 & 0.031 \\
\hline $\mathrm{Ca}$ & 0.698 & 0.207 & 0.223 & 0.359 & 0.006 & & 0.000 \\
\hline $\mathrm{Na}$ & & & 0.749 & 0.640 & 0.020 & & 0.000 \\
\hline $\mathrm{K}$ & & & 0.015 & 0.019 & 1.799 & & 0.001 \\
\hline $\mathrm{Ba}$ & & & & & 0.009 & & \\
\hline $\mathrm{F}$ & & & & & 0.963 & 0.003 & \\
\hline $\mathrm{OH}^{*}$ & & & & & 3.037 & & \\
\hline Total & 8.012 & 8.007 & 5.001 & 5.000 & 19.519 & 2.999 & 2.000 \\
\hline
\end{tabular}

End-members (mol. \%)

\begin{tabular}{lrrrr} 
Almandine & 54.53 & 65.53 & An 22.6 & An 35.3 \\
Andradite & 1.85 & 2.48 & Ab 75.9 & Ab 62.9 \\
Grossular & 21.51 & 4.41 & Or 1.6 & Or 1.8 \\
Pyrope & 21.10 & 26.40 & & \\
Spessartine & 0.98 & 1.12 & & \\
Uvarovite & 0.03 & 0.06 & & \\
\hline
\end{tabular}

Zn mobilization took place over a longer range, at least several $\mathrm{mm}$. In places the spinel in garnet II was transformed at a later stage to sphalerite-chlorite pseudomorphs, indicating sulphur mobility.

The preservation of early mineral assemblages and textural domains seems to exclude operation of a significant fluid flux that would have been instrumental in promoting compositional changes. Yet, the two reactions above, with their corresponding textures, indicate that significant quantities of ions were mobilized. Equigranular matrix aggregates of Opx $+\mathrm{Bt}+\mathrm{Pl} \mathrm{II} \pm \mathrm{Kfs}$ in samples Klt-1 and H232 appear as local equilibrium assemblages formed during decompression metamorphism. As the HP protoliths are commonly free of biotite, it is probable that fluids accompanying decompressions were hydrous with a significant fluorine content, as Bt in several samples contains $0.5-1.2$ wt. \% $\mathrm{F}$ and exceptionally (metabasite PlsGrt2) 2.7 wt. \% F.

\subsection{The GASP barometry}

Pressure estimates on several samples with a range of wholerock $\mathrm{Ca}$ abundances indicate the robust character of the net transfer reaction products underlying the GASP barometry. This is demonstrated by consistent maximum $\mathrm{P}$ estimates

relatively rich in Zn, and iii) low-Zn hercynitic spinel in cordierite-biotite migmatite. Sample Klt-1 contains low$\mathrm{Zn}$ hercynite in the kyanite consumption sites, resembling granulite I in the study above, but with a difference in the occurrence of spinel with 4 wt. \% $\mathrm{ZnO}$ as tiny particles in newly formed garnet II (Fig. 4c).

Compared to the $\mathrm{Zn}$ whole-rock concentration of 60 ppm in Klt-1, this represents a case of exceptionally strong preference of $\mathrm{Zn}$ for the spinel structure, resulting in $\mathrm{Zn}$ enrichment factor of $500 \times$. It is probable that of 2.3 GPa (2.2-2.3 GPa at 950 and $1000^{\circ} \mathrm{C}$; Tab. 12) obtained for a range of mineral compositions (Grt: Grs $=0.222-0.077, \mathrm{Pl}: \mathrm{An}=0.23-0.11)$. These values are considered as minimum pressure estimates.

The difference between the new pressure estimates and some previously published ones, e.g. 1.3-1.5 GPa (Pin and Vielzeuf 1988, and review of published estimates in O’Brien and Rötzler 2003; Janoušek et al. 2006b; Kotková 2007; Faryad 2011) can be explained by differences in selection of mineral domains for 
Tab. 12 GASP barometry data

\begin{tabular}{llllll}
\hline sample & Klt-1 & Klt-4 & Pls-1 & ZH-4 & Klt-20 \\
\hline $\mathrm{X}_{\text {Grs }}$ & 0.196 & 0.222 & 0.077 & 0.215 & 0.037 \\
$\mathrm{X}_{\text {An }}$ & 0.20 & 0.20 & 0.11 & 0.226 & 0.09 \\
\hline $\mathrm{P}(\mathrm{GPa})$ & & & & & \\
$950^{\circ} \mathrm{C}$ & 2.23 & 2.24 & 2.19 & 2.16 & 1.72 \\
$1000^{\circ} \mathrm{C}$ & 2.36 & 2.37 & 2.32 & 2.30 & 1.83 \\
\hline
\end{tabular}

analysis, choice of geobarometer, and calculation procedure.

Preliminary data on omphacite relics preserved as inclusions in garnet of mafic granulites (partly retrogressed mafic eclogites) from the BLGM indicates compositions of $\mathrm{Jd}_{28}$ (Faryad et al. 2010) and a suggestion of pressure near 2.2 GPa. Štípská et al. (2013) mentioned omphacite inclusions in Grt and estimated pressures near 2.0 GPa from a locality near our sample Klt-1. Such omphacite compositions point to pressures near the estimates obtained by GASP barometry on felsic granulites in the present study.

\subsection{Protolith, a melt-depleted residue or a restite-poor high-pressure melt? Variability of the felsic granulites in the BLGM}

The "ordinary" felsic kyanite-garnet granulites with a composition close to granite or rhyolite, which are predominant in the Moldanubian HP-HT granulite massifs, have been viewed as chemically undepleted with respect to alkalis (except $\mathrm{Cs}$ ) and $\mathrm{Zr}$, the latter reflecting zircon saturation levels in the igneous protoliths (Janoušek et al. 2004). However, the current work documents the presence of another, so far unrecognized class, designated here as the residual (type 2) granulites. Compared with pristine type 1 granulites, exemplified by sample Klt-4, these are Ky-rich, more peraluminous and more siliceous rocks stripped of some alkalis, much of $\mathrm{Zr}$ and a number of other elements. For instance, felsic type 2 granulites from the Plešovice quarry contain (if compared with pristine, type 1 granulites) low $\mathrm{K}_{2} \mathrm{O}, \mathrm{Na}_{2} \mathrm{O}$ and $\mathrm{CaO}$, as well as high $\mathrm{SiO}_{2}$ and normative corundum, and feature very low $\mathrm{Zr}$ abundances, often less than $50 \mathrm{ppm}$, even close to nil. Four samples of felsic kyanite-garnet granulite analysed by Strejček (1986) are clearly of the type 2 . The new analyses in the current work show normative plagioclase compositions between $\mathrm{An}_{05}$ and $\mathrm{An}_{10}$, and normative corundum contents 2.5 to $3.5 \mathrm{wt}$. \%, which correspond to c. 3 vol. \% kyanite, depending on the garnet abundance.

Interestingly, highly silicic (c. 76 wt. \% $\mathrm{SiO}_{2}$ ) Ky-rich residual granulites, low in $\mathrm{CaO}$ and extremely impoverished in $\mathrm{Zr}$ (Klt-20) surround a large hyperpotassic granulite body at Kokotín on the slopes of Mt. Klet' (Janoušek et al. 2013). Also, three layers, up to five $m$ thick, of hyperpotassic granulites rich in zircon occur in the Plešovice quarry (Vrána 1989), although a direct spatial link to the residual (type 2) granulites in their vicinity has not yet been demonstrated.

Based on the experimental work of Huang and Wyllie (1975, 1986), the hyperpotassic granulites have been interpreted as dry, high-pressure melts (Vrána 1989), most likely derived from the common felsic calc-alkaline granulites and modified by Grt-, Ap- and Zrn-dominated fractional crystallization, with or without crystal accumulation (Janoušek et al. 2007). Experiments have shown that during such dry, HP melting, orthoclase is the first phase to enter the non-eutectic melt, while quartz and kyanite remain in the residue (Vrána 1989; Schreyer 1999).

It should be stressed that the loss of alkalis in residual (type 2) granulites is relative and was not severe enough to lead to compositions greatly different from strongly fractionated, rather K-rich granites. Regardless, if compared with pristine $\left(\mathrm{S}_{1}\right)$ granulites of type 1 , such as Klt-4, the residual granulites seem to be stripped of some of the Or component that shows a complementary enrichment in the hyperpotassic types (see fig. 13 in Janoušek et al. 2007).

In order to test the hypothesis that type 2 granulites represent residua left after extraction of variable proportions of the hyperpotassic melt and to constrain the potential amount of such a melt lost, we have used the major-element based mixing test, commonly invoked in magma mixing scenarios (Castro et al. 1990; Janoušek et al. 2000). As shown by Fourcade and Allègre (1981) the mass-balance mixing equation for major elements can be rearranged so that it yields, for concentrations of several elements/oxides, a straight line in a plot of $C_{A}-C_{B}$ vs. $C_{M}-C_{B}$ (A and $\mathrm{B}$ being the end-members and $\mathrm{M}$ their putative mixture), with the slope corresponding to the fraction $f$ of the end member $A$. In our case (Fig. 11), the pristine granulite Klt-4 is viewed as a 'mixture' of the potentially residual Klt-20 and the relatively basic hyperpotassic granulite UK2 from Janoušek et al. (2007). The data define a straight line, confirming the genetic hypothesis. The least-squares regression fit indicates that the 'residual' granulite Klt-20 may have lost c. 20 wt. \% of hyperpotassic melt. Accordingly, residual (type 2) granulites should have originally exceeded the volume of perpotassic granulites by a factor of at least 5 .

The mineral assemblages of the type 2 granulites record high pressures for samples Pls-1, 2.3 GPa, and Klt-20, $1.8 \mathrm{GPa}$, both at $1000^{\circ} \mathrm{C}$. A relative abundance of kyanite, and absence or rarity of kyanite inversion to sillimanite, support conditions near the metamorphic peak for compositional depletion. However, the extremely low $\mathrm{MgO}$ content in Klt-20 and the presence of nearly pure almandine with a FeOt/MgO ratio of 28 in the same rock indicate that removal of some (significant) quantity of 


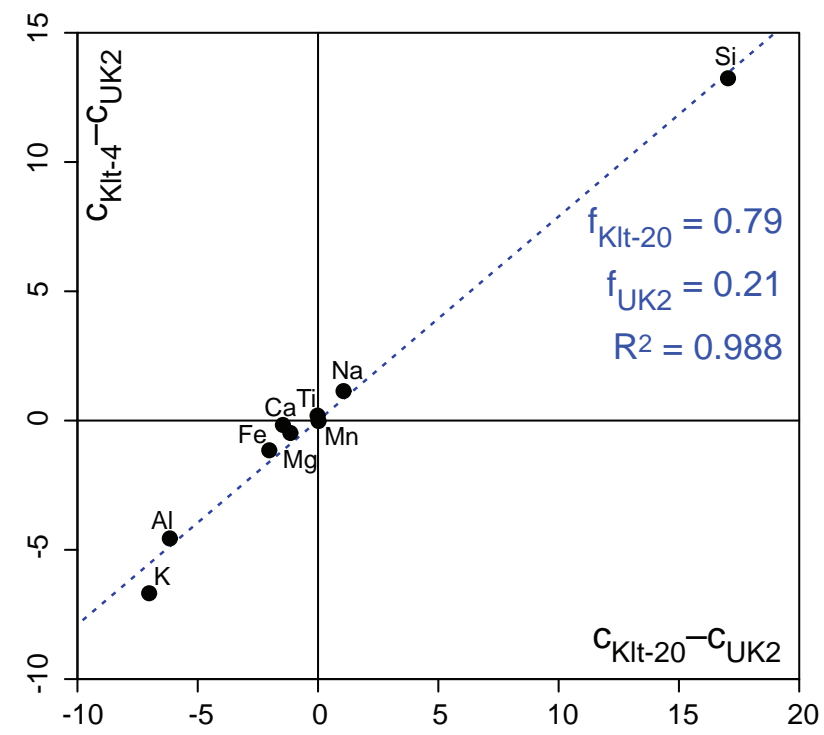

Fig. 11 Major-element based mixing test (Fourcade and Allègre 1981) showing that the type 2 granulite Klt-20 may represent a residue, which has lost c. $21 \mathrm{wt}$ \% high-pressure melt with composition of the hyperpotassic granulite UK2 (taken from Janoušek et al. 2007). Source was assumed to be the 'pristine' $\left(D_{1}\right)$ type 1 granulite Klt-4. See text for further discussion.

$\mathrm{Mg}$ and Ca was also probably involved. Accordingly, the non-eutectic partial melting that most likely resulted in depletion of Ky-rich siliceous granulites and separation of high-pressure melts parental to the hyperpotassic zircon-rich garnet granulites took place under eclogitefacies conditions. Three major types of felsic granulites can be thus recognised:

a) calc-alkaline felsic kyanite-garnet granulites (type 1),

b) kyanite-rich residual (type 2) felsic granulites (mostly of alkali feldspar leucogranite composition, normative $\mathrm{An}_{05-10}$, exceptionally $\mathrm{An}_{03}$ ),

c) hyperpotassic garnet granulites, Grt- or Di-bearing (Plešovice and Lhotka types).

\subsection{Occurrence of local domains with higher oxygen fugacity carrying magnetite}

Granulites of the Blanský les Massif formed at relatively low oxygen fugacity compatible with the widespread occurrence of accessory graphite (Vrána 1992; Vrána et al. 2010) (Fig. 9d) and pyrrhotite in felsic rocks, which are devoid of magnetite. Basic to intermediate granulites carry the assemblage ilmenite-pyrrhotite and are also free of magnetite.

The association of a $60 \mathrm{~m}$ boudin of intermediate granulite H232 with felsic granulite H232E shows that domains with a higher oxygen fugacity existed in the BLGM. It is possible that conditions for increased oxygen fugacity were established as late as during the decompression stage. This scenario is supported by the absence of magnetite inclusions in the early minerals (Grt I) and by rather low calculated Adr content in garnet in both samples. It is uncertain whether the martitization of magnetite to hematite in sample H232E was supergene or whether it was endogenous. Information available at present does not permit an estimation of the number and locations of additional magnetite-bearing domains in the BLGM, as secondary magnetite in numerous partly serpentinized peridotite bodies significantly contributes to the regional magnetic field, recorded by airborne magnetometry.

\subsection{Uncertainty concerning early metamorphic history of mafic granulites - did all samples experience true eclogite-facies metamorphic conditions?}

Worth noting is the fact that typical mafic granulites often carry ilmenite as a product of titanite breakdown, whereas rutile is rare. Rutile would be expected as a relict mineral, if mafic granulites were formed by transformation of eclogites. Typical mafic granulites commonly contain garnet that is rimmed by $\mathrm{Pl}+\mathrm{Opx}$ symplectite. Such texture indicates that garnet was unstable under LP granulite-facies conditions and that it originally equilibrated at higher pressures. The problem in identification of the earlier (eclogite-facies) history is that omphacitic pyroxene is mostly absent. Sample Klt-1 of granodiorite composition carries rare inclusions of diopsidic clinopyroxene in garnet which are free of any evidence for decompression reaction from former omphacite. One possible explanation for the absence (or rarity) of preserved mafic eclogite relics is in contrasting reactivities of various lithologies during pressure release under high $\mathrm{T}$. At one extreme are the type 2 granulites with their sodic (low-Ca) plagioclase and low-Grs garnets that have remained "frozen" during decompression from the HP stage. At the other extreme are the mafic granulites, which were derived from mafic eclogite and were probably much more reactive during the nearly isothermal decompression, i.e. at $800-900^{\circ} \mathrm{C}$. The major factor in the extensive transformation of eclogite to mafic granulite was probably the instability of Grs-rich garnet and omphacitic pyroxene during decompression.

\subsection{Fluid-triggered partial de-alkalization of felsic granulites in sillimanite stability field}

Unlike the near-peak HP loss of some alkalis due to limited HP melting described above, the production of sillimanite II-quartz domains proceeded mainly under subsolidus conditions. This is the conventional interpretation found in the literature on amphibolite-facies rocks in the Moldanubian Zone (Losert 1968, 1977) and 
various metamorphic units abroad (e.g., Buddington and Leonard 1962). The preferred sites of this type of partial de-alkalization were either newly produced shear foliations or (semi-) brittle fractures. A similar process could have taken place in other terranes with production of newly formed kyanite, if the superimposed conditions were in the kyanite stability field (Vrána 1973). At low pressures, such as in acid to intermediate volcanic rocks, hydrothermally induced partial de-alkalization produced andalusite-rich products (Vernon et al. 1987; Taner and Martin 1993). In the BLGM, in granulite samples affected by de-alkalization and containing residual sillimanite and quartz (Fig. 8a-b), approximately $5 \%$ of the rock was altered. This would result in the loss of c. $0.40 \mathrm{wt}$. $\% \mathrm{~K}_{2} \mathrm{O}$ $+\mathrm{Na}_{2} \mathrm{O}+\mathrm{CaO}$ to a supercritical water solution. In turn, this process suggests that a significant amount of waterrich fluids percolated through the granulite massif during amphibolite-facies retrogression and is consistent with the significant amount of water needed to account for the extensive breakdown of Grt to Bt observed elsewhere in $\mathrm{S}_{3}$ fabrics in the BLGM. From a geochemical point of view, such inferred fluid migration points to open-system behaviour of the felsic granulites at this stage.

\subsection{Uncertainty concerning compositional changes of felsic granulites in the process of polyphase metamorphism}

This study documents a variety of metamorphic reactions, including near-peak processes under eclogite-facies conditions, decompression reactions in granulite-facies, and superimposed amphibolite-facies modifications. All these processes exhibit a highly heterogeneous distribution and/or intensity. It is important to consider the possible influences of the individual reactions on granulite composition, whose intensity and extent vary in individual domains of the massif and from sample to sample.

It has long been thought that chemical compositions in high-grade Moldanubian rocks behaved conservatively and that many processes were isochemical. A strong support for this view was the interpretation that migmatization of Moldanubian paragneisses was a nearly isochemical process, based on major-element geochemistry (Suk 1964). In contrast, Vrána and Bártek (2005) presented evidence for major chemical changes accompanying retrogression of Sil-Bt paragneisses to muscovite-biotite gneisses of the Kaplice Unit, driven by fluid flux localized in a large syn-metamorphic shear zone.

In the felsic HP granulites, the interpretation of limited, if any, melt loss was based on the fact that some LILE ratios susceptible to melt extraction (e.g., $\mathrm{K} / \mathrm{Rb}, \mathrm{Rb} / \mathrm{Sr}$ ) were not modified beyond the ranges for typical crustal lithologies (Fiala 1987a, b; Vellmer 1992; Janoušek et al. 2004). Moreover, this concept was supported by comparison of felsic granulite compositions with those of their likely protoliths (Ordovician-Silurian metaigneous rocks of Saxothuringian provenance; Janoušek et al. 2004). On this basis a near isochemical character of the HP metamorphism was inferred and only significant $\mathrm{U}$, Th, Cs, $\pm \mathrm{Pb}$, and Li loss was postulated (Fiala 1987a, b; Vellmer 1992; Janoušek et al. 2004; Lexa et al. 2011). The trouble is that the 'statistical' approach using large datasets covering a number of granulite massifs, often coming from various laboratories and restricted to part of the overall variability (cf. Janoušek et al. 2004) tends to obscure more subtle differences that have potentially large petrogenetic significance.

The current detailed petrological study, supported by high-quality major-element data from a single laboratory, has allowed recognition of two superimposed processes affecting the compositions of BLGM felsic granulites. In this way were recognized the felsic type 2 granulites, i.e. residual rocks which lost part of their alkalis and much of their $\mathrm{Zr}$ in the process of small-scale, non-eutectic melting, and which are thus complementary to the small bodies of hyperpotassic granulites. The existence of such residual granulite domains was anticipated but previously unproven (Vrána 1989; Janoušek et al. 2007). Moreover, partial base-cation loss, due to fluid-assisted amphibolite-facies de-alkalization and leading to a formation of quartz-sillimanite bands along $S_{3}$ shear domains, has been documented. Relative volumes affected by this process can be estimated at 5 to $10 \mathrm{vol}$. \% of the respective domains.

Lastly, processes involving mobilization and transport of ions on a microscale and associated with decompression metamorphism include mobilization of $\mathrm{Zn}$ (for spinel), P (for apatite II in H296-AR), and $\mathrm{Na}, \mathrm{Ca}, \mathrm{Fe}$, $\mathrm{Mg}$ (for Pl II, Spl, Grt II replacements of kyanite). Especially in the last case the total mass volumes mobilized are important on a geological scale (e.g. due to extensive occurrence of Grt II); although transfer distances did not exceed several $\mathrm{mm}$ or $\mathrm{cm}$.

\subsection{Eclogite-facies metamorphism and terminological remarks}

The enigmatic joint occurrence of upper mantle Spl- and Grt-peridotites with a variety of granulites and bodies of Bt or Grt-Bt orthogneisses in the BLGM (and, indeed, other HP-HT granulite massifs in the Bohemian Massif) was noticed long time ago (Kodym 1972). These disparate lithologic associations indicate that the BLGM is an incoherent unit, but the question remains as to when and under what $\mathrm{P}-\mathrm{T}$ conditions the dissimilar rock types were juxtaposed.

The maximum pressure estimates from felsic Moldanubian granulites previously relied on extrapolation from 
more mafic lithologies, which represent only a small fraction of the HP massifs. As these conditions lie above those required for plagioclase stability in quartz tholeiites, they are in fact eclogites (O’Brien 2006). However the timing and $\mathrm{P}-\mathrm{T}$ conditions of their incorporation into the prevalent felsic mass has remained largely unconstrained, and thus it was uncertain to what extent such $\mathrm{P}-\mathrm{T}$ results can be relevant to the most voluminous felsic lithologies.

Our new petrological results from structurally and geochemically well-constrained samples, for the first time indicate pressures in felsic Moldanubian granulites as high as $2.2-2.3 \mathrm{GPa}$. The comparable maximum pressure estimates obtained from basic granulites (Faryad et al. 2010; Štípská et al. 2013 and this work), combined with our results suggest that much of the HP and retrograde history of the felsic and mafic granulites was shared. In turn, juxtaposition of the felsic and mafic types had to be earlier than, or contemporaneous with, near-peak metamorphism.

Undoubtedly, the HP-HT stage in felsic granulites took place deep in the eclogite-facies field, outside the stability of orthopyroxene in rocks of granitic composition. Due to obsolete terminology, which did not envision that so siliceous lithologies could reach such extreme conditions (Eskola 1915), these eclogite-facies rocks have traditionally been termed 'felsic granulites', and because this term is ingrained in the literature, it is retained in this contribution. Moreover, basic to intermediate, eclogite-facies metaigneous rocks have been called 'eclogite', where they are enclosed in MP metasedimentary assemblages, such as the Varied and Monotonous units. However, basic to intermediate rocks in the Gföhl Unit that experienced similar peak P-T conditions have been referred to as 'mafic granulites'. This terminology has caused considerable confusion among petrologists unfamiliar with the local literature and traditional terminology, and clearly requires a revision.

\section{Conclusions}

Data presented in this contribution provide evidence for processes and mineral assemblages previously unrecognized, or not fully appreciated, in the South Bohemian HP-HT Granulite Complex. Our petrological study of a large sample set documents the operation of several important processes, as follows.

1. Evidence for early stages of eclogite-facies metamorphism in felsic rocks with preservation of their original textural relations and largely intact HP-HT mineral assemblages. Such domains occur in a close proximity to sites dominated by phases produced by later decompression reactions. The retrogression reactions, often incomplete, were clearly associated with transfer of ions on the microscale.

2. Consistent high-pressure estimates, 2.2-2.3 GPa, are newly documented, not only for mafic granulite, but also for $S_{1}$ fabrics in felsic granulite (type 1). Such pressure estimates demonstrate that much of the HP history was shared by the felsic and mafic metaigneous lithologies. This observation has tectonic implications about their subduction and introduction into the base of the thickened Variscan crust. Corresponding temperatures possibly reached at least $900-950{ }^{\circ} \mathrm{C}$, according to previously published estimates.

3. In the south-eastern sector of the Blanský les Granulite Massif occur small bodies of Kfs-dominated hyperpotassic granulites with Grt (Plešovice type) or minor Di (Lhotka type). They are interpreted as a product of non-eutectic HP melting. The recent discovery of an exceptionally large (length $200 \mathrm{~m}$ ) body of Plešovice type hyperpotassic granulite at Kokotín shows that these rock types may be more common than previously thought.

4. The occurrences of Grt-bearing hyperpotassic granulites are accompanied by residual (type 2) granulites, which contain more quartz and kyanite and less Ca with $\mathrm{Zr}$ than the more common felsic type 1 granulites. The field relations, mass balance of major-elements, and previously published experimental data on HP partial melting show that the type 2 granulites represent a residue after extraction of considerable amounts of non-eutectic melt, which subsequently evolved by fractional crystallization of mainly Grt and Kfs to produce the hyperpotassic granulites.

5. Residual (type 2) granulites, with their low normative anorthite content, carry sodic plagioclase $\left(\mathrm{An}_{05-10}\right)$ and garnet with low grossular component. Due to this composition, type 2 granulites escaped some decompression reactions, such as formation of plagioclase rims around kyanite and garnet breakdown. The HP mineral assemblages were thus effectively "frozen" during decompression (except rare kyanite inversion to sillimanite and garnet biotitization in some samples).

6. On a regional scale, felsic granulites are characterized by a reducing assemblage of graphite, pyrrhotite and ilmenite. However, one $60 \mathrm{~m}$ boudin of mafic granulite and adjacent felsic granulite both contain magnetite, demonstrating that, at least locally, the oxygen fugacity was elevated during granulite-facies retrogression.

7. Partial depletion of alkalis in the sillimanite stability field occurred along late $S_{3}$ shear foliation, resulting in the formation of feldspar-free quartz-sillimanite bands. Activity of the related hydrous fluids coincided with amphibolite-facies retrogression.

8. The superposition of several processes, each localized in certain domains, resulted in a patchwork-like varia- 
bility in mineral assemblages and chemical composition of the entire Blanský les Granulite Massif. In order to gain more insight into the areal extent of individual domains, protolith variability, and differences in metamorphic development, further detailed petrological, geochemical, and geochronological studies are needed.

9. Two examples of syn-metamorphic changes in whole-rock composition are demonstrated by a combination of petrological and geochemical methods: (a) near-peak depletion of some felsic granulites (type 2) by extraction of (non-eutectic) HP partial melts that subsequently crystallized as hyperpotassic granulites; (b) local base-cation loss during partial de-alkalization under amphibolite-facies conditions, accompanying fluid flux along $\mathrm{S}_{3}$ shear domains (formation of quartzsillimanite bands). Such processes indicate that not all Moldanubian felsic granulites are closed-system rocks with respect to their primary protolith compositions, or the most pristine felsic (type 1) granulites.

10. Most, if not all, mafic and felsic 'granulites' experienced HT eclogite-facies metamorphic conditions, and thus revision of their nomenclature may be required.

Acknowledgements. The present study was conducted in the frame of the GAČR Project P210-11-2358 (to VJ). P. Gadas, R. Čopjaková and R. Škoda operated the microprobe in joint sessions on mineral analyses. We are thankful to the handling editor, Gordon Medaris Jr., as well as P. O'Brien and an anonymous reviewer, for critical and helpful comments that have greatly improved the language and contents of the manuscript.

\section{References}

Aftalion M, Bowes DR, VRÁna S (1989) Early Carboniferous $\mathrm{U}-\mathrm{Pb}$ zircon age of garnetiferous, perpotassic granulites, Blanský les Massif, Czechoslovakia. Neu Jb Mineral, Mh 4: 145-152

Ague JJ (1994) Mass transfer during Barrovian metamorphism of pelites, south-central Connecticut; I, Evidence for changes in composition and volume. Amer J Sci 294: 989-1057

AlBARÉdE F (1995) Introduction to Geochemical Modeling. Cambridge University Press, Cambridge, pp 1-543

Ashworth JR, Reverdatto VV, Kolobov VY, Sheplev VS, BRYXINA NA (1998) Textures of diffusion-controlled reaction in contact-metamorphosed Mg-rich granulite, Kokchetav area, Kazakhstan. Mineral Mag 62: 213-224

BEHR HJ (1961) Beiträge zur petrographischen und tektonischen Analyse des sächsischen Granulitgebirges. Freiberg Forsch H C 119: 1-144

BEHR HJ (1980) Polyphase shear zones in the granulite belts along the margins of the Bohemian Massif. J Struct Geol 2: 249-254
Benisek A, Dachs E, Kroll H (2010) A ternary feldsparmixing model based on calorimetric data: development and application. Contrib Mineral Petrol 160: 327-337

BREY GP, KÖHLER T (1990) Geothermobarometry in fourphase lherzolites II. New thermobarometers, and practical assessment of existing thermobarometers. J Petrol 31: 1353-1378

Buddington AF, LEONARD BF (1962) Regional geology of the St. Lawrence County magnetite district, northwest Adirondacks, New York. USGS Professional Papers 376: pp 1-145

CArswell DA, O'Brien PJ (1993) Thermobarometry and geotectonic significance of high-pressure granulites: examples from the Moldanubian Zone of the Bohemian Massif in Lower Austria. J Petrol 34: 427-459

Castro A, De la Rosa JD, Stephens WE (1990) Magma mixing in the subvolcanic environment: petrology of the Gerena interaction zone near Seville, Spain. Contrib Mineral Petrol 105: 9-26

Chen F (2002) Garnet Sm-Nd and U-Pb systems: a case study of a granulite from the European Variscan belt. Chinese Sci Bull 47: 1284-1288

COOKe RA, O'Brien PJ (2001) Resolving the relationship between high $\mathrm{P}-\mathrm{T}$ rocks and gneisses in collisional terranes: an example from the Gföhl gneiss-granulite association in the Moldanubian Zone, Austria. Lithos 58: 33-54

Debon F, Le Fort P (1983) A chemical-mineralogical classification of common plutonic rocks and associations. Trans Roy Soc Edinb, Earth Sci 73: 135-149

Debon F, Le Fort P (1988) A cationic classification of common plutonic rocks and their magmatic associations: principles, method, applications. Bull Minéral 111: 493-510

DudeK A (1980) The crystalline basement block of the Outer Carpathians in Moravia: BrunoVistulicum. Rozpr Čs Akad Věd, ř mat přír Věd 90: 3-85

Eskola P (1915) On the relation between the chemical and mineralogical composition in the metamorphic rocks of the Orijärvi region. Bull Commission Géol Finland 44: 109-145

FARYAD SW (2011) Distribution and geological position of high-/ultrahigh-pressure units within the European Variscan Belt: a review. In: DobrzhinetsKayA LF, FARYad SW, Wallis S, Cuthbert S (eds) UltrahighPressure Metamorphism: 25 Years After the Discovery of Coesite and Diamond. Elsevier, Amsterdam, pp 361-397

FARyad SW, Nahodilová R, Dolejš D (2010) Incipient eclogite facies metamorphism in the Moldanubian granulites revealed by mineral inclusions in garnet. Lithos 114: 54-69

Fediuková E (1971) Andalusite in granulites of the Bohemian Massif. Tschermaks mineral petrogr Mitt 15: 249-257 
Fediuková E (1978) Mafic minerals from granulites of the borehole Holubov (South Bohemian Moldanubicum). Sbor geol Věd, ložisk Geol Mineral 19: 169-198

Fiala J, MatĚJovsKÁ O, VAŇKovÁ V (1987a) Moldanubian granulites and related rocks: petrology, geochemistry, and radioactivity. Rozpr Čs Akad Věd, ̌r mat prír Věd 97: 1-102

Fiala J, MatěJovská O, VaňKová V (1987b) Moldanubian granulites: source material and petrogenetic considerations. Neu Jb Mineral, Abh 157: 133-165

Fiala J, Fuchs G, Wendt JI (1995) Moldanubian Zone - stratigraphy. In: Dallmeyer RD, Franke W, Weber $\mathrm{K}$ (eds) Pre-Permian Geology of Central and Eastern Europe. Springer, Berlin, pp 417-428

Finger F, Steyrer HP (1995) A tectonic model for the eastern Variscides: indications from a chemical study of amphibolites in the south-eastern Bohemian Massif. Geol Zbor Geol Carpathica 46: 137-150

Fourcade S, Allègre CJ (1981) Trace elements behavior in granite genesis: a case study. The calc-alkaline plutonic association from the Querigut Complex (Pyrénées, France). Contrib Mineral Petrol 76: 177-195

FraněK J, Schulmann K, Lexa O (2006) Kinematic and rheological model of exhumation of high pressure granulites in the Variscan orogenic root: example of the Blanský les granulite, Bohemian Massif, Czech Republic. Mineral Petrol 86: 253-276

FraněK J, Schulmann K, LeXa O, Tomek Č, Edel JB (2011a) Model of syn-convergent extrusion of orogenic lower crust in the core of the Variscan belt: implications for exhumation of high-pressure rocks in large hot orogens. J Metamorph Geol 29: 53-78

FraněK J, Schulmann K, Lexa O, Ulrich S, ŠTíPSKÁ P, Haloda J, Týcová P (2011b) Origin of felsic granulite microstructure by heterogeneous decomposition of alkali feldspar and extreme weakening of orogenic lower crust during the Variscan orogeny. J Metamorph Geol 29: $103-130$

Franke W (2000) The mid-European segment of the Variscides: tectonostratigraphic units, terrane boundaries and plate tectonic evolution. In: Franke W, HAAK V, ONCKEN O, TANner D (eds) Orogenic Processes: Quantification and Modelling in the Variscan Belt. Geological Society London Special Publications 179: 35-56

Friedl G, Cooke R, Finger F, McNaughton NJ, Fletcher A (2003) U-Pb SHRIMP dating and trace element investigations on multiple zoned zircons from a SouthBohemian granulite. J Czech Geol Soc 48: 51-52

Friedl G, Finger F, Paquette JL, von Quadt A, McNaughTON NJ, Fletcher IR (2004) Pre-Variscan geological events in the Austrian part of the Bohemian Massif deduced from U/Pb zircon ages. Int J Earth Sci (Geol Rundsch) 93: 802-823

Friedl G, Cooke R, Finger F, McNaughton N, Fletcher I (2011) Timing of Variscan HP-HT metamorphism in the Moldanubian Zone of the Bohemian Massif: U-Pb SHRIMP dating on multiply zoned zircons from a granulite from the Dunkelsteiner Wald Massif, Lower Austria. Mineral Petrol 102: 63-75

Fritz H (1995) The Raabs Series: a probable Variscan suture in the SE Bohemian Massif. Jb Geol B -A 138: 639-653

Frost BR, Barnes CG, Collins WJ, Arculus RJ, Ellis DJ, Frost CD (2001) A geochemical classification for granitic rocks. J Petrol 42: 2033-2048

Fuchs G (1976) Zur Entwicklung der Böhmischen Masse. Jb Geol B -A 119: 45-61

Fuchs G, Matura A (1976) Zur Geologie des Kristallins der südlichen Böhmischen Masse. Jb Geol B -A 119: 1-43

Ganguly J, Cheng W, Tirone M (1996) Thermodynamics of aluminosilicate garnet solid solution: new experimental data, an optimized model, and thermometric applications. Contrib Mineral Petrol 126: 137-151

Gebauer D, Friedl G (1994) A 1.38 Ga protolith age for the Dobra orthogneiss (Moldanubian zone of the southern Bohemian Massif, NE-Austria): evidence from ionmicroprobe (SHRIMP) dating of zircon. J Czech Geol Soc 39: 34-35

GREw ES (1996) Borosilicates (exclusive of tourmaline) and boron in rock-forming minerals in metamorphic environments. In: Grew ES, ANOvitz LM (eds) Boron: Mineralogy, Petrology and Geochemistry. Mineralogical Society of America Reviews in Mineralogy 33, Washington, pp 387-502

HARLEY SL (1989) The origins of granulites; a metamorphic perspective. Geol Mag 126: 215-247

Harley SL (2013) 'Slow' and 'fast' granulites: Ti, temperature, time, tectonics. In: Fitzsimons CW, CLARK C (eds) Granulites \& Granulites 2013, Hyderabad, 16-20 January 2013, Program and Abstracts. The Institute of Geoscience Research (TiGeR), Department of Applied Geology, Curtin University, pp 32

Hasalová P, Janoušek V, Schulmann K, ŠtíPská P, Erban V (2008) From orthogneiss to migmatite: geochemical assessment of the melt infiltration model in the Gföhl Unit (Moldanubian Zone, Bohemian Massif). Lithos 102: 508-537

Holub FV (1997) Ultrapotassic plutonic rocks of the durbachite series in the Bohemian Massif: petrology, geochemistry and petrogenetic interpretation. Sbor geol Věd, ložisk Geol Mineral 31: 5-26

Huang WL, Wyllie PJ (1975) Melting reactions in the system $\mathrm{NaAlSi}_{3} \mathrm{O}_{8}-\mathrm{KAlSi}_{3} \mathrm{O}_{8}-\mathrm{SiO}_{2}$ to 35 kilobars, dry and with excess water. J Geol 83: 737-748

Huang WL, Wyllie PJ (1986) Phase relationships of gabbro-tonalite-granite-water at 15 kbar with applications to differentiation and anatexis. Amer Miner 71: 301-316

Hutchison CS (1975) The norm, its variations, their calculation and relationships. Schweiz mineral petrogr Mitt 55: 243-256 
IndARes A, Martignole J (1985) Biotite-garnet geothermometry in the granulite facies; the influence of $\mathrm{Ti}$ and $\mathrm{Al}$ in biotite. Amer Miner 70: 272-278

JAKEŠ P (1997) Melting in high-P region - case of Bohemian granulites. Acta Univ Carol, Geol 41: 113-125

JANOUŠEK V, HoluB FV (2007) The causal link between HPHT metamorphism and ultrapotassic magmatism in collisional orogens: case study from the Moldanubian Zone of the Bohemian Massif. Proc Geol Assoc 118: 75-86

JANOUŠEK V, FrÝdA J, VoKURKa K (1996) Polyphase development of the Moldanubian granulites: evidence from the $\mathrm{Rb}-\mathrm{Sr}$ and Sm-Nd isotopic study of the Blanský les granulite massif (Czech Republic). In: TreloAr P, O’Brien PJ (eds) What drives Metamorphism and Metamorphic Reactions: Heat Production, Heat Transfer, Deformation and Kinetics? Kingston University, pp 43-44

Janoušek V, Bowes DR, Braithwaite CJR, Rogers G (2000) Microstructural and mineralogical evidence for limited involvement of magma mixing in the petrogenesis of a Hercynian high-K calc-alkaline intrusion: the Kozárovice granodiorite, Central Bohemian Pluton, Czech Republic. Trans Roy Soc Edinb, Earth Sci 91: 15-26

JANOUŠEk V, Finger F, Roberts MP, FrýdA J, Pin C, Dolejš D (2004) Deciphering the petrogenesis of deeply buried granites: whole-rock geochemical constraints on the origin of largely undepleted felsic granulites from the Moldanubian Zone of the Bohemian Massif. Trans Roy Soc Edinb, Earth Sci 95: 141-159

JANOUŠEK V, FARROW CM, ERBAN V (2006a) Interpretation of whole-rock geochemical data in igneous geochemistry: introducing Geochemical Data Toolkit (GCDkit). J Petrol 47: 1255-1259

Janoušek V, Gerdes A, VRÁnA S, Finger F, Erban V, Friedl G, BraithWAIte CJR (2006b) Low-pressure granulites of the Lišov Massif, Southern Bohemia: Viséan metamorphism of Late Devonian plutonic arc rocks. J Petrol 47: 705-744

Janoušek V, Krenn E, Finger F, Míková J, Frýda J (2007) Hyperpotassic granulites from the Blanský les Massif (Moldanubian Zone, Bohemian Massif) revisited. J Geosci 52: 73-112

Janoušek V, Gerdes A, Holub FV, Verner K (2010) Dating Variscan ultrapotassic intrusions in the Bohemian Massif - separating myth from reality. In: Конút M (ed) Datovanie 2010. Zborník abstraktov. Štátny geologický ústav Dionýza Štúra, Bratislava, pp 15-16

JANOUŠEK V, VRÁNA S, FrANĚK J (2013) New occurrence of hyperpotassic granulites in the Blanský les granulite Massif (southern Bohemia). Zpr geol Výzk v Roce 2012: 30-34 (in Czech with English abstract)

Kodyм O (1972) Multiphase deformation in the Blanský les granulite massif. Krystalinikum 9: 91-105

KoDym O (1981) Vysvětlivky k základní geologické mapě ČSSR 1:25 000, list 32-212 Nová Ves. Czech Geological Survey, Prague, pp 1-50
KoDym O (1985) Vysvětlivky k základní geologické mapě ČSSR 1:25 000, list 32-214 Křemže. Czech Geological Survey, Prague, pp 1-70

Kodym O, Jakeš P, Schovánek P (1978) Granulite und ultramafische Gesteine aus der Strukturbohrung Holubov. Sbor geol Věd, Geol 32: 7-47

Kossmat F (1927) Gliederung des variszischen Gebirgsbaues. Abh Sächs geol Landesamts 1: 1-39

KoTKovÁ J (2007) High-pressure granulites of the Bohemian Massif: recent advances and open questions. J Geosci 52: 45-71

Kotková J, Harley SL (1999) Formation and evolution of high-pressure leucogranulites: experimental constraints and unresolved issues. Phys Chem Earth (A) 24: 299-304

Kotková J, Harley SL (2010) Anatexis during highpressure crustal metamorphism: evidence from garnetwhole-rock REE relationships and zircon-rutile $\mathrm{Ti}-\mathrm{Zr}$ thermometry in leucogranulites from the Bohemian Massif. J Petrol 51: 1967-2001

Koziol AM, Newton RC (1988) Redetermination of the anorthite breakdown reaction and improvement of the plagioclase-garnet- $\mathrm{Al}_{2} \mathrm{SiO}_{5}$-quartz geobarometer. Amer Miner 73: 216-223

KrETz R (1983) Symbols for rock-forming minerals. Amer Miner 68: 277-279

Kröner A, O’Brien PJ, Nemchin AA, Pidgeon RT (2000) Zircon ages for high pressure granulites from South Bohemia, Czech Republic, and their connection to Carboniferous high temperature processes. Contrib Mineral Petrol 138: 127-142

Lexa O, Schulmann K, Janoušek V, ŠTípská P, Guy A, RACEK M (2011) Heat sources and trigger mechanisms of exhumation of HP granulites in Variscan orogenic root. J Metamorph Geol 29: 79-102

Linnemann U, Gehmlich M, Tichomirowa M, Buschmann B, Nasdala L, Jonas P, Lützner H, Bombach K (2000) From Cadomian subduction to Early Palaeozoic rifting: the evolution of Saxo-Thuringia at the margin of Gondwana in the light of single zircon geochronology and basin development (Central European Variscides, Germany). In: Franke W, HaAk V, Oncken O, TANner D (eds) Orogenic Processes: Quantification and Modelling in the Variscan Belt. Geological Society London Special Publications 179: pp 131-153

Loomis TP (1979) A natural example of metastable reactions involving garnet and sillimanite. J Petrol 20: 271-292

LOSERT J (1968) On the genesis of nodular sillimanitic rocks. Reports XXIII International Geological Congress 4: $109-122$

Losert J (1977) Sillimanite fibrolitique du Moldanobicum du massif de Bohême et ses analogies avec celle des massifs cristalins varisques de l'Europe occidentale. Coll Intenn CNRS 243: 329-340 
Maierová P, Lexa O, Schulmann K, Štípská P (in print) Contrasting tectono-metamorphic evolution of orogenic lower crust in the Bohemian Massif: A numerical model. Gondwana Res, doi: 10.1016/j.gr.2012.08.020

Massonne H-J, Nasdala L (2003) Characterization of an early metamorphic stage through inclusions in zircon of a diamondiferous quartzofeldspathic rock from the Erzgebirge, Germany. Amer Miner 88: 883-889

Massonne H-J, Fockenberg T (2012) Melting of metasedimentary rocks at ultrahigh pressure - insights from experiments and thermodynamic calculations. Lithosphere 4: 269-285

Medaris G JR, Wang H, Jelínek E, Mihaljevič M, Jakeš P (2005) Characteristics and origins of diverse Variscan peridotites in the Gföhl Nappe, Bohemian Massif, Czech Republic. Lithos 82: 1-23

Medaris JR LG, Beard BL, Jelínek E (2006) Mantle-derived, UHP garnet pyroxenite and eclogite in the Moldanubian Gföhl nappe, Bohemian Massif: a geochemical review, new $\mathrm{P}-\mathrm{T}$ determinations, and tectonic interpretation. Int Geol Rev 48: 765-777

Messiga B, Bettini E (1990) Reactions behaviour during kelyphite and symplectite formation: a case study of mafic granulites and eclogites from the Bohemian Massif. Eur J Mineral 2: 125-144

Mora CI, VALLEy JW (1985) Ternary feldspar thermometry in granulites from the Oaxacan Complex, Mexico. Contrib Mineral Petrol 89: 215-225

O'BRIEN PJ (2000) The fundamental Variscan problem: high-temperature metamorphism at different depths and high-pressure metamorphism at different temperatures. In: Franke W, Haak V, Oncken O, Tanner D (eds) Orogenic Processes: Quantification and Modelling in the Variscan Belt. Geological Society London Special Publications 179: pp 369-386

O’Brien PJ (2006) Type-locality granulites: high-pressure rocks formed at eclogite-facies conditions. Mineral Petrol 86: $161-175$

O'BRIEN PJ (2008) Challenges in high-pressure granulite metamorphism in the era of pseudosections: reaction textures, compositional zoning and tectonic interpretation with examples from the Bohemian Massif. J Metamorph Geol 26: 235-251

O'Brien PJ, Carswell DA (1993) Tectonometamorphic evolution of the Bohemian Massif: evidence from high pressure metamorphic rocks. Geol Rundsch 82: 531-555

O'Brien PJ, Rötzler J (2003) High-pressure granulites: formation, recovery of peak conditions and implications for tectonics. J Metamorph Geol 21: 3-20

Owen JV, Dostal J (1996) Contrasting corona structures in mafic granulite from the Blanský Les Complex, Bohemian Massif, Czech Republic. Canad Mineral 34: 959-966

Peccerillo A, TaYlor SR (1976) Geochemistry of Eocene calc-alkaline volcanic rocks from the Kastamonu area,
Northern Turkey. Contrib Mineral Petrol 58: 63-81

Pin C, Marini F (1993) Early Ordovician continental break-up in Variscan Europe - Nd-Sr isotope and traceelement evidence from bimodal igneous associations of the southern Massif Central, France. Lithos 29: 177-196

Pin C, Vielzeuf D (1988) Les granulites de haute-pression d'Europe moyenne temoins d'une subduction eo-hercynienne; implications sur l'origine des groupes leptynoamphiboliques. Bull Soc Géol France 4: 13-20

Powell R (1985) Geothermometry and geobarometry. A discussion. J Geol Soc, London 142: 29-38

Prince CI, KošLer J, Vance D, GÜnther D (2000) Comparison of laser ablation ICP-MS and isotope dilution REE analyses - implications for Sm-Nd garnet geochronology. Chem Geol 168: 255-274

Racek M, Ští́ské P, Pitra P, Schulmann K, Lexa O (2006) Metamorphic record of burial and exhumation of orogenic lower and middle crust: a new tectonothermal model for the Drosendorf Window (Bohemian Massif, Austria). Mineral Petrol 86: 221-251

RAHEIM A, GREEN DH (1974) Experimental determination of the temperature and pressure dependence of the $\mathrm{Fe}-\mathrm{Mg}$ partition coefficient for coexisting garnet and clinopyroxene. Contrib Mineral Petrol 48: 179-203

Rajlich P, Synek J, Šarbach M, Schulmann K (1986) Hercynian-thrust related shear zones and deformation of the Varied Group on the contact of granulites (southern Moldanubian, Bohemian Massif). Geol Rundsch 75: 665-683

Romer RL, Rötzler J (2011) The role of element distribution for the isotopic dating of metamorphic minerals. Eur J Mineral 23: 17-33

SCHREYER W (1999) Experimental aspects of UHP metamorphism: granitic systems. Int Geol Rev 41: 701-710

Schulmann K, Lexa O, Štípská P, Racek M, TajČmanová L, Konopásek J, Edel JB, Peschler A, Lehmann J (2008) Vertical extrusion and horizontal channel flow of orogenic lower crust: key exhumation mechanisms in large hot orogens? J Metamorph Geol 26: 273-297

Schulmann K, Konopásek J, Janoušek V, Lexa O, Lardeaux JM, Edel JB, ŠTíPská P, UlRich S (2009) An Andean type Palaeozoic convergence in the Bohemian Massif. C R Geosci 341: 266-286

Sengupta P, Dasgupta S, Bhattacharya PK, Mukherjee M (1990) An orthopyroxene-biotite geothermometer and its application in crustal granulites and mantle-derived rocks. J Metamorph Geol 8: 191-197

Siebel W, Raschka H, Irber W, Kreuzer H, Lenz KL, HöHndorf A, Wendt I (1997) Early Palaeozoic acid magmatism in the Saxothuringian belt: new insights from a geochemical and isotopic study of orthogneisses and metavolcanic rocks from the Fichtelgebirge, SE Germany. J Petrol 38: 203-230

Slabý J (1983) Modal composition and petrochemistry of granulites of the Lišov and Blanský les Mts. massifs, 
southern Bohemia. Čas Mineral Geol 28: 41-60 (in Czech with English abstract)

Sláma J, Košler J, Pedersen R (2007) Behaviour of zircon in high-grade metamorphic rocks: evidence from $\mathrm{Hf}$ isotopes, trace elements and textural studies. Contrib Mineral Petrol 154: 335-356

Sláma J, Košler J, Condon DJ, Crowley Jl, Gerdes A, Hanchar JM, Horstwood MSA, Morris GA, Nasdala L, Norberg N, Schaltegger U, Schoene B, Tubrett MN, Whitehouse MJ (2008) Plešovice zircon - a new natural reference material for $\mathrm{U}-\mathrm{Pb}$ and $\mathrm{Hf}$ isotopic microanalysis. Chem Geol 249: 1-35

StReCKeISEN A (1976) To each plutonic rock its proper name. Earth Sci Rev 12: 1-33

STREJČEK M (1986) Petrology of granulites in the Plešovice quarry near Český Krumlov. Unpublished MSci. Thesis, Charles University, Prague (in Czech)

Suk M (1964) Material characteristics of the metamorphism and migmatization of Moldanubian paragneisses in Central Bohemia. Krystalinikum 2: 71-105

SvottKa M, KošLer J, Venera Z (2002) Dating granulitefacies structures and the exhumation of lower crust in the Moldanubian Zone of the Bohemian Massif. Int J Earth Sci (Geol Rundsch) 91: 373-385

ŠTíPSKÁ P, Powell R (2005) Does ternary feldspar constrain the metamorphic conditions of high-grade meta-igneous rocks? Evidence from orthopyroxene granulites, Bohemian Massif. J Metamorph Geol 23: 627-647

ŠTíPSKÁ P, SCHULMANn K, KRÖNER A (2004) Vertical extrusion and middle crustal spreading of omphacite granulite: a model of syn-convergent exhumation (Bohemian Massif, Czech Republic). J Metamorph Geol 22: 179-198

ŠTípská P, Powell R, White RW, BALdwin JA (2010) Using calculated chemical potential relationships to account for coronas around kyanite: an example from the Bohemian Massif. J Metamorph Geol 28: 97-116

Štípská P, Powell R, Racek M, Lexa O (2013) Interaction of eclogite with felsic granulite in the orogenic root, Bohemian Massif. In: Fitzsimons CW, Clark C (eds) Granulites \& Granulites 2013, Hyderabad, 16-20 January 2013, Program and Abstracts. The Institute of Geoscience Research (TiGeR), Department of Applied Geology, Curtin University, pp 59

TajČmanová L, Konopásek J, Connolly JAD (2007) Diffusion-controlled development of silica-undersaturated domains in felsic granulites of the Bohemian Massif (Variscan belt of Central Europe). Contrib Mineral Petrol 153: 237-250

TAJČMANOVÁ L, KonopáseK J, KošLER J (2009) Distribution of zinc and its role in the stabilization of spinel in highgrade felsic rocks of the Moldanubian domain (Bohemian Massif). Eur J Mineral 21: 407-418

Tajčmanová L, Abart R, Neusser G, Rhede D (2011) Growth of plagioclase rims around metastable kyanite during decompression of high-pressure felsic granulites (Bohemian Massif). J Metamorph Geol 29: 1003-1018

Tajčmanová L, Abart R, Wirth R, Habler G, Rhede D (2012) Intracrystalline microstructures in alkali feldspars from fluid-deficient felsic granulites: a mineral chemical and TEM study. Contrib Mineral Petrol 164: 715-729

TANer MF, Martin RF (1993) Significance of dumortierite in an aluminosilicate-rich alteration zone, Louvicourt, Quebec. Canad Mineral 31: 137-146

TindLe A (2012) Mineral recalculation software. Accessed on December 7, 2013, at http://www.open.ac.uk/earthresearch/tindle/AGTWebPages/AGTSoft.html

Tollmann A (1982) Großräumiger variszischer Deckenbau im Moldanubikum und neue Gedanken zum Variszikum Europas. Geotekt Forsch 64: pp 1-91

Tropper P, Konzett Y, Finger F (2005) Experimental constraints on the formation of high-P/high-T granulites in the Southern Bohemian Massif. Eur J Mineral 17: 343-356

Trubač J, JanoušEk V, VRána S, Wiegand B (2012) Nature, tectonic setting and likely origin of the Palaeoproterozoic $(\sim 2.1 \mathrm{Ga})$ Světlík orthogneisses (southern Bohemia). Miner Slov 44: 110

van Breemen O, Aftalion M, Bowes DR, Dudek A, Mísar̆ Z, Povondra P, VRÁna S (1982) Geochronological studies of the Bohemian Massif, Czechoslovakia, and their significance in the evolution of Central Europe. Trans Roy Soc Edinb, Earth Sci 73: 89-108

Vellmer C (1992) Stoffbestand und Petrogenese von Granuliten und granitischen Gesteinen der südlichen Böhmischen Masse in Niederösterreich. Unpublished PhD. thesis, Georg-August-Universität Göttingen, pp 1-111

Verner K, Ž́́́ J, Nahodilová R, Holub FV (2008) Magmatic fabrics and emplacement of the cone-sheet-bearing Knížecí Stolec durbachitic pluton (Moldanubian Unit, Bohemian Massif): implications for mid-crustal reworking of granulitic lower crust in the Central European Variscides. Int J Earth Sci (Geol Rundsch) 97: 19-33

VERNON RH, FloOd RH, D'ARCy WF (1987) Sillimanite and andalusite produced by base-cation leaching and contact metamorphism of felsic igneous rocks. J Metamorph Geol 5: 439-450

Villaseca C, Barbero L, Herreros V (1998) A re-examination of the typology of peraluminous granite types in intracontinental orogenic belts. Trans Roy Soc Edinb, Earth Sci 89: 113-119

VRÁNA S (1973) Model of aluminium silicate accretion in metamorphic rocks. Contrib Mineral Petrol 41: 73-82

VRÁNA S (1979) Polyphase shear folding and thrusting in the Moldanubicum of southern Bohemia. Věst Ústř Úst geol 54: 75-86

VRÁNA S (1989) Perpotassic granulites from southern Bohemia: a new rock-type derived from partial melting of crustal rocks under upper mantle conditions. Contrib Mineral Petrol 103: 510-522 
VRÁNA S (1992) The Moldanubian Zone in Southern Bohemia: polyphase evolution of imbricated crustal and upper mantle segments. In: KUKAL Z (ed) Proceedings of the $1^{\text {st }}$ International Conference on the Bohemian Massif. Czech Geological Survey, Prague, pp 331-336

VRÁNA S (1998) New type of hyperpotassic granulite in the Blanský les granulite Massif. Zpr geol Výzk v Roce 1997: 52-53 (in Czech with English abstract)

VRÁNA S (2011) Twenty five years since discovery of garnet hyperpotassic granulites in southern Bohemia, Czech Republic. Zpr geol Výzk v Roce 2010: 189-191 (in Czech with English abstract)

VRÁNA S, BÁRTEK J (2005) Retrograde metamorphism in a regional shear zone and related chemical changes: the Kaplice Unit of muscovite-biotite gneisses in the Moldanubian Zone of southern Bohemia, Czech Republic. J Czech Geol Soc 50: 43-57
VRÁnA S, ŠRÁmeK J (1999) Geological interpretation of detailed gravity survey of the granulite complex in southern Bohemia and its structure. Věst Čes geol úst 74: 261-277

VRÁna S, ŽÁK K, Veselovský F, JaČKová I (2010) Carbon isotopic composition of graphite in the granulite complex of southern Bohemia. Zpr geol Výzk v Roce 2009: 259-262 (in Czech with English abstract)

Wendt JI, Kröner A, Fiala J, Todt W (1993) Evidence from zircon dating for existence of approximately 2.1 Ga old crystalline basement in southern Bohemia, Czech Republic. Geol Rundsch 82: 42-50

Wendt JI, KRÖNER A, Fiala J, TODT W (1994) U-Pb zircon and Sm-Nd dating of Moldanubian HP/HT granulites from south Bohemia, Czech Republic. J Geol Soc, London 151: 83-90 